UNIVERSIDADE DE SÃO PAULO

FACULDADE DE FILOSOFIA, LETRAS E CIÊNCIAS HUMANAS

DEPARTAMENTO DE CIÊNCIA POLÍTICA

PROGRAMA DE PÓS-GRADUAÇÃO EM CIÊNCIA POLÍTICA

\title{
ACESSO À JUSTIÇA: ESTUDO DE TRÊS JUIZADOS ESPECIAIS CÍVEIS DE SÃO PAULO
}

Erik Macedo Marques

\begin{abstract}
Dissertação apresentada ao Programa de Pós-Graduação em Ciência Política, do Departamento de Ciência Política da Faculdade de Filosofia, Letras e Ciências Humanas da Universidade de São Paulo, para obtenção do título de Mestre em Ciência Política.
\end{abstract}

Orientador: Prof. Dra. Maria Tereza Sadek

São Paulo

2006 


\section{UNIVERSIDADE DE SÃO PAULO}

FACULDADE DE FILOSOFIA, LETRAS E CIÊNCIAS HUMANAS

DEPARTAMENTO DE CIÊNCIA POLÍTICA

PROGRAMA DE CIÊNCIA POLÍTICA

\section{ACESSO À JUSTIÇA: ESTUDO DE TRÊS JUIZADOS ESPECIAIS CÍVEIS DE SÃO PAULO}

Erik Macedo Marques

São Paulo

2006 


\section{DEDICATÓRIA}

Para Aidil Signoretti Macedo, Mãe no sentido mais belo do termo. 


\section{AGRADECIMENTOS}

É impossível que os projetos que assumimos em nossas vidas cheguem a um bom termo se não pudermos contar com pessoas capazes de nos auxiliar nos inúmeros percalços que sempre estão presentes nos caminhos que trilhamos. No caso desta dissertação não poderia ser diferente. A compreensão e o auxílio foram de fundamental importância para que este neófito na área da Ciência Política pudesse chegar ao término deste trabalho.

A primeira pessoa a agradecer é a minha orientadora, Maria Tereza Sadek, cuja dedicação em seus trabalhos permitiram a produção desta dissertação.

Agradeço também aos funcionários da secretaria do Departamento de Ciência Política (Márcia, Rai, Vivian, Léo, Ana Maria,) por sempre estarem dispostos a ajudar quando preciso. Agradeço à Coordenação de Aperfeiçoamento de Pessoal de Nível Superior (CAPES) por ter concedido bolsa para realização do mestrado.

Agradeço à Evelyn Levy, que me deu a oportunidade de conhecer um novo mundo no trabalho da administração pública.

Agradeço aos meus amigos de mestrado IvoYoshida, Ivan Borin e Frederico Normanha por tanto me auxiliarem no dia-a-dia da vida acadêmica.

Agradeço também aos meus amigos Arnaldo Gobetti, Sérgio Mota, Alessandra Sanchez, Sandra Monteiro, Teresa Cristina Pereira, Euricles Moraes, Cícero Moraes, Ilka DeMeo e Francisco Andrada pelos valorosos auxílios nos trabalhos de produção desta dissertação, e também por me orientar nos mais diversos aspectos da vida conturbada de um jovem mestrando. 


\section{RESUMO}

Os Juizados Especiais Cíveis são atualmente no Brasil a principal experiência para a efetivação do acesso à justiça, constituindo-se em uma via judiciária estatal de baixo custo e fácil acesso aos cidadãos para a solução de seus conflitos e garantia de seus direitos. Pesquisas e levantamentos sobre o desempenho desse modelo indicam que, ao invés de conflitos cotidianos, é cada vez maior a presença de demandas de consumidores contra prestadores de serviço público. A presente dissertação analisa os tipos de autores, reclamados e ações interpostas em três Juizados Especiais Cíveis localizados em regiões de diferentes perfis sócioeconômicos do Município de São Paulo com o objetivo de verificar a presença deste tipo de litígio e a hipótese se esses Juizados tornaram-se de fato um "balcão de reclamações" contra a prestação de serviços públicos.

\section{PALAVRAS-CHAVE}

Sistema de justiça, administração da justiça, democratização do acesso à justiça, juizados especiais, prestação de serviços públicos. 


\section{ABSTRACT}

Currently, in Brazil, the Small Claims Courts are the main experience of effectiveness in access to justice. They are state judiciary institutions that offer low costs and easy access to the citizens for the solution of their conflicts and guarantee of their rights. Researches and surveys on this model's performance indicate that there is an increasing presence of demands from consumers against private agents that render public services, instead of other daily conflicts. The present study analyzes the types of plaintiffs, defendants and judicial actions in three Small Claims Courts located in regions of different social-economic profiles in São Paulo City. The aim is to verify the presence of this type of litigation and the hypothesis whether these Courts had become in fact a " claims' counter" against private agents that render public services.

\section{KEY WORDS}

System of justice, justice administration, democratization of access to justice, public services rendering. 


\section{SUMÁRIO}

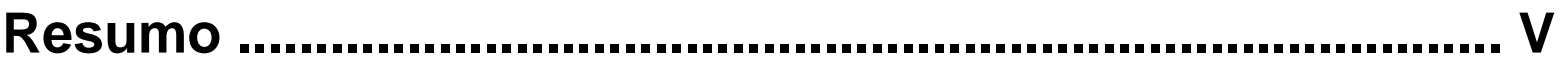

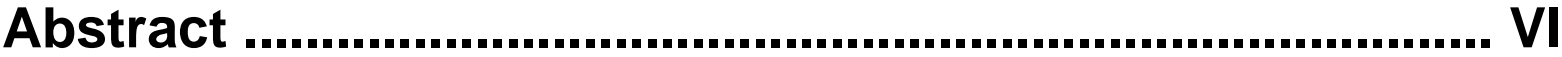

Índice ................................................................................. VIII

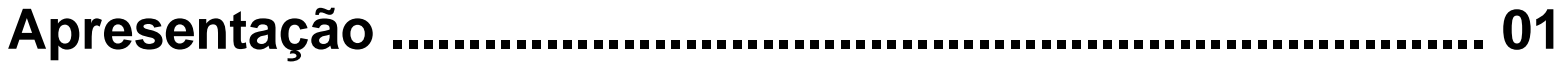

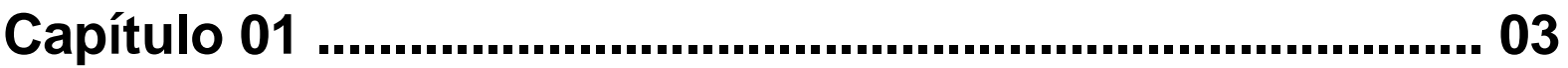

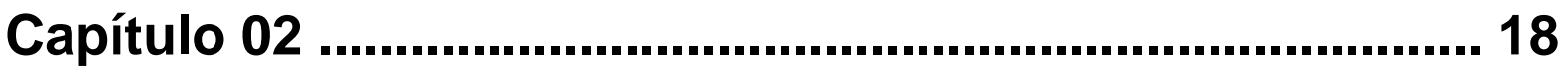

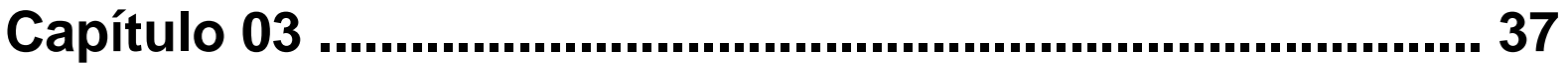

Considerações Conclusivas ................................................ 74

Referências Bibliográficas .................................................. 77 


\section{ÍNDICE}

Apresentação

Capítulo 01 - Acesso à Justiça e os Juizados Especiais

Cíveis no Brasil

1.1. Cidadania e Acesso à Justiça: a Experiência Brasileira e da Cidade

de São Paulo 03

\section{Capítulo 02 - Os Serviços Públicos como Questão dos} Juizados Especiais

2.1. A Prestação de Serviços Públicos após a Reforma do Estado

Brasileiro 18

2.2. O Direito do Consumidor

2.3. Pesquisas e Levantamentos Anteriores sobre as Demandas dos

Juizados Especiais

Capítulo 03 - Pesquisa de Campo: Feitos Distribuídos em

Três Juizados Especiais da Comarca de São Paulo 37

3.1. Hipóteses e desenvolvimento da pesquisa ................................. 37

3.2. Os Juizados Pesquisados ....................................................... 39

3.3. Resultados da Pesquisa ............................................................ 48

Considerações Conclusivas ................................................. 74

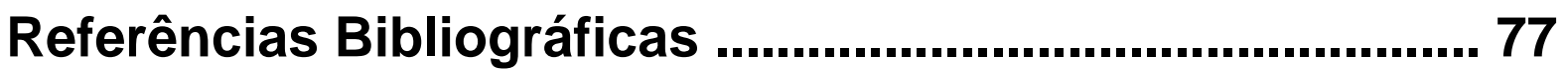




\section{Apresentação}

A presente dissertação pretende analisar o perfil das demandas dos Juizados Especiais Cíveis com vistas a verificar se de fato estas novas instituições judiciais estão se transformando em “balcão de reclamação” sobre a prestação de serviços públicos.

Os Juizados Especiais Cíveis foram instalados no Brasil a partir de experiências anteriores internacionais, diante dos movimentos de acesso à justiça, bem como após a implementação anterior de aparelhos como os Juizados de Pequenas Causas e os Juizados Informais de Conciliação. A Lei 9.099/95 definiu o modelo dos JEC’́s que vige nos Estados, ampliando a sua competência com relação aos sistemas nacionais anteriores e adotando formas de solução do litígio que primam pela oralidade, celeridade, tratamento igualitário entre as partes e eqüidade nas decisões.

Os Juizados foram concebidos para tornar efetivo o direito de acesso à justiça para a população, principalmente a de baixa renda, reduzindo custos e simplificando os procedimentos judiciais, com o objetivo de solucionar os litígios de modo célere e eficaz, primando pela busca do acordo entre as partes. O que se buscou com a criação desses Juizados foi a expansão da cidadania por meio do acesso à uma decisão estatal a conflitos que estavam fora da esfera judicial por motivos de possibilidade das partes ou de altos custos impostos aos litigantes nos processos. A tentativa do modelo foi de trazer aos canais estatais estes tipos de demandas que não chegam ao Poder Judiciário ou que não obtinham do mesmo uma resposta satisfatória, em outras palavras, o modelo tenta solucionar o problema da litigiosidade contida.

Porém, conforme observaremos no decorrer da presente dissertação, as referências bibliográficas, os levantamentos e pesquisas que tratam da performance desses Juizados indicam uma crescente participação dos conflitos de consumidores contra prestadores de serviços públicos, em comparação com outros tipos de conflitos cotidianos (como direitos de vizinhança, consumo de bens privados, contratos individuais privados etc). Entretanto, são poucos os levantamentos específicos para determinar se este tipo de demanda está mesmo abarrotando os JEC's, e o quanto está presente no dia-a-dia desses órgãos judiciais. Este é o foco do presente estudo, que, através do levantamento dos feitos de três Juizados Especiais da comarca de São Paulo, pretende levantar subsídios que permitam a 
análise sobre a participação desse tipo de litígio neste novo modelo de efetivação do acesso à justiça.

O trabalho está dividido em três partes. No primeiro capítulo trataremos da questão do acesso à justiça como direito fundamental à cidadania, bem como do processo de implementação do modelo dos juizados especiais no Brasil e na cidade de São Paulo. Esta análise tem como objetivo introduzir o tema do acesso à justiça e indicar as bases de formação e instalação dos JEC's na comarca palco do estudo, explorando as diferentes experiências do Tribunal de Justiça de São Paulo na expansão do modelo.

No segundo capítulo iremos analisar rapidamente a literatura sobre o processo de reforma do Estado brasileiro nos anos 90, sobre os principais dispositivos de defesa do consumidor, e sobre os levantamentos e pesquisas anteriores acerca da performance dos Juizados tanto em São Paulo, quanto em outras cidades e Estados brasileiros. Este capítulo tem como objetivo analisar o processo brasileiro de delegação da prestação dos serviços públicos, que permitiu a introdução no cenário político e administrativo de entes reguladores e de normas legais que atuam sobre novos aspectos do serviço público pela primeira vez presentes no cenário brasileiro.

O Código de Defesa do Consumidor complementa a base para fixarmos o desenvolvimento da dissertação ao introduzir novos direitos para o cidadão tanto para garantir a eficaz prestação dos serviços públicos quanto o acesso à justiça, dispondo em seu texto normas que viabilizam o questionamento nos diversos poderes da federação brasileira das práticas adotadas pelas empresas concessionárias dos serviços públicos.

Os levantamentos e pesquisas analisados subsidiam as hipóteses da pesquisa de campo, demonstrando que as diversas incursões científicas nos dados dos feitos judiciais dos Juizados indicam uma forte presença de demandas de consumo em seus conflitos e de prestadores de serviços públicos como tipo de reclamados.

O terceiro capítulo analisa os dados da pesquisa de campo. Esta pesquisa foi realizada em três Juizados Especiais Cíveis da comarca de São Paulo, localizados em regiões de diferentes perfis sócio-econômicos. As variáveis levantadas foram o tipo de autor, tipo de reclamado e tipo de ação, com vistas a aceitar ou rejeitar a hipótese da presença crescente de litígios sobre os serviços públicos neste novo modelo de efetivação do acesso à justiça. Considerações finais sobre os aspectos tratados encerram a dissertação. 


\section{Capítulo 01 - Acesso à Justiça e os Juizados Especiais Cíveis no Brasil}

O presente capítulo tem como objetivo introduzir o tema dos Juizados Especiais, relacionando-o ao conceito de cidadania, na medida da garantia dos direitos por uma via de fácil acesso e baixo custo ao cidadão na solução de seus conflitos. Serão tratados os conceitos e a evolução dessa nova forma de acesso à justiça, com especial atenção para a sua implementação na comarca de São Paulo, local dos Juizados Especiais pesquisados na presente dissertação.

\subsection{Cidadania e Acesso à Justiça: a Experiência Brasileira e da Cidade de São Paulo}

A realização da cidadania é relacionada a explicitação e defesa de direitos. Seja através do reconhecimento legislativo de diretos, como a promulgação do Código de Defesa do Consumidor; seja com o acesso do cidadão às informações e serviços que reparam o descumprimento desses direitos.

Partindo do reconhecimento e defesa de liberdades e direitos pelo Estado como alicerces da cidadania, hoje nos deparamos com um quadro de expansão contínua de direitos que impacta sobre as atividades dos poderes do Estado; e que requer uma iniciativa positiva deste, por meio da formulação de políticas públicas, no sentido de concretizar a cidadania.

Historicamente, a esfera de direitos do cidadão ampliou-se, abarcando não apenas direitos civis e políticos, mas também direitos sociais e econômicos, como direito à educação, à saúde, ao trabalho, aos bens culturais, ao acesso à tecnologia, aos bens científicos e à informação ${ }^{1}$. Enfim, o conceito de cidadania englobou a distribuição social de bens materiais e imateriais que são objeto de políticas públicas governamentais.

Amartya Sen (1999, p. 10) formulou o conceito de desenvolvimento econômico como o provimento de liberdades reais que as pessoas desfrutam. Trata-se de tornar possível para as pessoas o desenvolvimento de suas próprias capacidades, e permitir 
seu acesso a oportunidades individuais de participação econômica, política e superação de limitações e privações.

Nesse sentido, práticas de gestão e práticas de políticas públicas são um importante parâmetro para julgar o respeito aos cidadãos. Eficiência e eficácia governamentais podem ser mensuradas em indicadores tangíveis e apontam para a medida do cumprimento dos objetivos do Estado em observar e concretizar a cidadania. Trata-se de garantir que as pessoas tenham acesso a determinados serviços ou programas públicos para que outras oportunidades individuais sejam alcançadas.

O movimento de expansão e fortalecimento da cidadania é contínuo. Uma de suas dimensões, a garantia das liberdades individuais por meio do acesso à justiça, também passa por esse fortalecimento. As políticas de acesso à justiça podem ser definidas, na forma proposta por Cunha (2001, p. 68), como uma forma diferenciada de solução dos conflitos sociais pelo Estado, que incorpora uma visão nova do Direito. Esta política promove acessibilidade, redução de custas processuais e da duração do processo, equaliza as partes litigantes, simplifica regras de produção de provas e torna o juiz um ator mais ativo e menos formal, simplificando os procedimentos e possibilitando ao magistrado a tomada de decisões em parâmetros de equidade.

Um dos primeiros autores a tratar o acesso à justiça como garantia da cidadania foi T. H. Marshall (1967, p. 63), que, em seu clássico Cidadania, Classe Social e Status, coloca os tribunais como as instituições mais intimamente ligadas aos direitos civis, direitos necessários à liberdade individual e precedente histórico em sua análise da evolução dos direitos. Para o autor, o conceito de cidadania resulta da combinação de três tipos de direitos: civis, políticos e sociais. O desenvolvimento independente dos direitos individuais consagra a necessidade das instâncias judiciais e do acesso às mesmas pelo cidadão para a sua correta efetividade.

Dos trabalhos recentes sobre o tema, o Projeto de Florença tornou-se um marco na análise de políticas de acesso à Justiça. A equipe capitaneada pelos autores Mauro Capelletti e Bryant Garth realizou um amplo estudo internacional sobre o assunto, e, de acordo com esses autores:

\footnotetext{
${ }^{1}$ Para uma análise histórica da evolução dos conceitos dos direitos humanos ver Comparato (2002).
} 
“O acesso à justiça pode ser encarado como o requisito fundamental - o mais básico dos direitos humanos - de um sistema jurídico moderno e igualitário que pretenda garantir, e não apenas proclamar os direitos de todos. ”(Capelletti e Garth, 2002, p. 12)

Em sua análise, os autores identificam dois principais obstáculos ao acesso efetivo à justiça: os custos judiciais e a possibilidade das partes. Ao primeiro estão relacionadas questões de pagamento das custas do processo, dos honorários advocatícios e do tempo que leva a solução do litígio. Concluem que as causas de valor relativamente pequeno são as mais prejudicadas pela barreira dos custos, de modo que a proporção dos gastos enfrentados nas ações cresce na medida em que se reduz o valor da causa. O tempo de demora dos processos participa nesta equação principalmente ao atuar como fator de pressão sobre os economicamente mais fracos para, ou abandonar a causa, ou realizar acordos de valores bem menores do que o pretendido.

A possibilidade das partes compõe-se das vantagens e desvantagens estratégicas que diferentes partes possuem. A disponibilidade de recursos financeiros é um dos primeiros fatores deste obstáculo. Aqueles que possuem recursos têm condições de litigar, e têm a capacidade de suportar por mais tempo a demora do litígio. Outro importante fator relativo a este obstáculo é a capacidade de se reconhecer um direito e de propor uma ação em sua defesa. Uma diversidade de fatores pode ser indicada como causa para a diferença de percepção de direitos subjetivos próprios e para a diferença de conhecimento sobre a maneira de se ajuizar uma demanda, tais como recursos financeiros, status social, educação, disposição psicológica etc. ${ }^{2}$ A situação torna-se mais complexa na medida da existência de direitos não-tradicionais, como direito ao meio ambiente saudável, de difícil reconhecimento para a maioria dos cidadãos.

O problema se agrava ao considerarmos que existem os litigantes “eventuais”, indivíduos com contatos isolados e pouco freqüentes com o sistema judicial, e os "habituais”, entidades mais desenvolvidas e com larga participação nos tribunais, sendo que os primeiros não participam de algumas vantagens dos segundos por não terem tanta

\footnotetext{
${ }^{2}$ Cabe citar, para esta barreira, a afirmação de Santos (2001, p. 170) “estudos revelam que a distância dos cidadãos com relação à administração da justiça é tanto maior quanto mais baixo é o estrato social a que pertencem, e que essa distância tem como causas próximas não apenas factores econômicos, mas também
} 
“experiência” em casos judiciais. Algumas destas vantagens são: o planejamento dos litígios, a economia de escala dada a grande quantidade de casos, oportunidades de desenvolver relações informais com as instâncias decisórias do caso, diluição dos riscos das demandas no maior número de casos, teste de estratégias para a garantia de expectativa mais favorável em casos futuros.

A conclusão do diagnóstico sobre as barreiras ao acesso à justiça indica que os obstáculos criados pelos sistemas judiciais são mais pronunciados para as pequenas causas e para os autores individuais, especialmente os pobres, e, ao mesmo tempo, vantagens estratégicas estão ligadas aos litigantes organizacionais, usuários constantes do sistema judiciário para a satisfação de seus interesses. A evolução e afirmação dos direitos de cidadania, aliados a esta situação de exclusão, provocou diversos movimentos para que os menos favorecidos no acesso à justiça pudessem superar estes obstáculos e terem a garantia da análise judicial de seus conflitos.

No levantamento de soluções práticas adotadas pelos diversos sistemas judiciais no mundo para superar essas barreiras e tornar efetivo o acesso à justiça, os autores identificaram uma seqüência evolutiva cronológica de três “ondas”’3. A primeira “onda” deste movimento foi a "assistência judiciária”. Esta tem como característica básica proporcionar serviços jurídicos aos pobres, especialmente o serviço de advogados, muitas vezes indispensáveis na compreensão de leis e procedimentos, bem como para ajuizar causas.

Este sistema foi implementado primeiramente nos EUA, e ao longo da década de 70 estendeu-se para França, Suécia, Inglaterra, Quebec no Canadá, Alemanha, Áustria, Holanda, Itália e Austrália. Porém esta “onda” encontra suas limitações em fatores como o número de advogados disponíveis, dotações orçamentárias próprias e cada vez maiores para atender a demanda dos pagamentos públicos aos advogados, riscos envolvidos na sucumbência em pequenas causas, e a atuação dos advogados exclusivamente para os setores economicamente mais desfavorecidos da sociedade, não atendendo demandas de importantes direitos difusos como os de consumidores e meio ambiente. No Brasil podemos citar como exemplos desta “onda” o instituto da advocacia pro bono, Defensorias Públicas

factores sociais e culturais, ainda que uns e outros possam estar mais ou menos remotamente relacionados com as desigualdades econômicas".

${ }^{3}$ Dada a evolução descontínua desses movimentos, bem como a sua superposição na implementação das políticas de acesso à justiça, os autores, apesar de identificar uma determinada ordem cronológica, denominam a sucessão destas novas formas de garantia dos direitos aos tribunais como “ondas”. 
(previstas na Constituição Federal, mas ainda não instaladas em todos os Estados) ${ }^{4}$, convênios firmados entre o Poder Público e advogados particulares, e atendimento em instituições de ensino jurídico.

A segunda “onda” de acesso à justiça é a representação dos interesses difusos em juízo, que adota uma nova concepção coletiva do processo judicial. O procedimento judicial, classicamente considerado como a defesa de interesses individuais, com esta nova "onda” passa a servir para interesses de toda uma coletividade. Este movimento parte da concepção da existência de novos direitos consagrados no Estado de Bem-Estar, e procura atuar na defesa coletiva de indivíduos conforme a lesão de direito difuso que os atinge, e não somente aos desfavorecidos economicamente. Exemplos de direitos intimamente ligados a esta nova "onda” são os direitos dos consumidores e direitos ao meio ambiente saudável. No Brasil, as instituições mais representativas desse movimento são o Ministério Público e associações de defesa do consumidor ${ }^{5}$.

A terceira “onda” identificada pelos autores originou-se do relativo sucesso das anteriores. Parte não apenas da idéia de proteção de direitos, mas da mudança de procedimentos judiciais para torná-los mais exeqüíveis. Deste modo foram criadas alternativas mais rápidas e menos custosas, como juízo arbitral, conciliação, “centros de justiça da vizinhança” e acordos por incentivos econômicos. Conforme Vianna et alli (1999, p. 159) houve uma ampliação das relações entre o Judiciário e o conjunto da população, expondo o tecido social à intervenção do direito, seus procedimentos e instituições. Os Juizados Especiais são o grande exemplo desta “onda”.

Este último autor também indica que, no Brasil, a seqüência evolutiva descrita no Projeto de Florença não se aplica in totum para os projetos nacionais de efetivação do acesso à justiça. Afirma que:

“O Brasil, a se observar a seqüência proposta pelos autores, teria atingido a terceira grande onda de democratização do acesso à Justiça sem que a intervenção estatal para garantir a eficácia na assistência judiciária tivesse sido plenamente cumprida - do que é

\footnotetext{
${ }^{4}$ Os Estados de Goiás e Santa Catarina ainda não possuem Defensorias Públicas instaladas. Para um diagnóstico sobre a Defensoria Pública no Brasil, seu perfil institucional e caracterização de seus integrantes ver Ministério da Justiça (2004). Para uma análise da defesa de direitos promovida pela Procuradoria de Assistência Judiciária (órgão estadual de atuação semelhante nesta seara às Defensorias Públicas no Estado de São Paulo), ver Cunha (1999).
} 
exemplo o fato de o instituto da Defensoria Pública não se ter generalizado no país - e sem que a proteção de interesses difusos conhecesse grande avanço, exceto no que se refere aos consumidores.”(Vianna et alli 1999)

Talvez este diagnóstico seja uma expressão específica de uma situação geral da defesa dos direitos civis no Brasil. Carvalho (2002), em seu livro Cidadania no Brasil, dispõe que os direitos civis são retardatários no período recente da história brasileira. Para o autor:

“... pode-se dizer que, dos direitos que compõe a cidadania, no Brasil são ainda os civis que apresentam as maiores deficiências em termos de seu conhecimento, extensão e garantia”(p. 210).

Para Carvalho (2002, pp. 209 a 217), houve a criação de novos institutos após o advento da Constituição de 1988, conhecida também como “Constituição Cidadã”, que procuraram recuperar este "atraso” na efetividade dos direitos civis.

Expõe o autor, como principais inovações trazidas com a Carta Constitucional, o direito de habeas data, instrumento processual por meio do qual o cidadão pode obter informações sobre dados nos registros públicos; o mandato de injunção, outro instrumento processual para exigir a regulamentação de dispositivos constitucionais; o tratamento do crime de racismo como inanfiançável e imprescritível, bem como a tortura como crime inafiançável e não passivo de anistia.

Leis advindas da nova ordem constitucional também são citadas como recuperação do relativo atraso na proteção dos direitos civis, como a lei de 1989 que definiu os crimes de preconceito de cor ou raça; a criação da Lei de Defesa do Consumidor em 1990. E também cita o Programa Nacional dos Direitos Humanos, criado em 1996. Os Juizados Especiais Cíveis e Criminais assumem para o autor grande relevância ao pretenderem simplificar, agilizar e baratear a prestação de justiça em causas cíveis de pequena complexidade e em infrações penais de menor potencial ofensivo.

\footnotetext{
${ }^{5}$ Uma análise deste tipo de “onda” no Brasil, especificamente do uso das ações civis públicas e ações populares, instrumentos judiciais que possibilitam a defesa de direitos difusos e coletivos, ver Vianna e Burgos (2003).
} 
De certa forma, a recuperação desse atraso provoca idiossincrasias no sistema de proteção dos direitos civis. Tanto o seu reconhecimento tardio, quanto o atraso nas medidas concretas de sua efetivação, obrigam os movimentos de mudança e reforma do sistema legislativo e judicial a contemplarem direitos e garantias dos mais antigos aos mais recentes, dos mais simples aos mais complexos, superpondo movimentos de transformação do sistema legal-judicial que, além de não se enquadrarem nas definições e análises da evolução desses instrumentos nos países centrais, muitas vezes deixam desprotegidas situações básicas de concretização da cidadania, como o exemplo da falta de assistência judiciária institucionalizada nas formas da Constituição.

A experiência de criação dos Juizados Especiais no Brasil teve o seu primeiro momento nos Conselhos de Conciliação e Arbitragem, no Rio Grande do Sul em 1982. Essa iniciativa originou-se em dois movimentos: o da Associação de Juizes do Rio Grande do Sul - AJURIS, e o do extinto Ministério da Desburocratização, do Governo Federal. Ambos convergiam para a idéia de reformas para a simplificação de procedimentos burocráticos, e de ampliação da cidadania, resultando na criação dos Conselhos como uma forma de democratizar o acesso à Justiça. ${ }^{6}$

Os Juizados de Pequenas Causas, criados com a aprovação da Lei 7.244, de 1984, representam o segundo grande momento no caminho das políticas de acesso à Justiça. Resultam não tanto de uma consideração das mudanças na prestação jurisdicional em torno da idéia de Justiça, mas de uma solução razoável diante da necessidade de reformas em um Estado que sofria os males de uma grave crise fiscal. Apesar desse viés, um dos principais efeitos da sua implementação foi a formação de alianças importantes no interior da comunidade jurídica acerca de pontos consensuais para uma reforma do Judiciário brasileiro.

Juizados Especiais de Pequenas Causas, organizado por Watanabe (1985), é uma das primeiras obras de análise deste sistema, com a contribuição de participantes diretos na criação e implementação deste novo procedimento judicial. Para este autor (Watanabe, 1985, pp. 02 e 03), a idéia dos Juizados de Pequenas Causas acompanha o fato de que muitos dos conflitos existentes na sociedade não são satisfatoriamente solucionados, seja por não encontrar uma resposta eficaz do aparelho judicial, seja por simplesmente não chegar às portas dessa instituição ao se crer que o Judiciário é lento, caro e

\footnotetext{
${ }^{6}$ Cunha (2004, p. 19), em sua análise da construção do sistema dos Juizados Especiais, indica que tanto a experiência do Tribunal de Justiça do Rio Grande do Sul quanto a iniciativa do Ministério da Desburocratização são as duas fontes do sistema conforme a literatura. Porém, indica que é possível identificar outros atores
} 
complicado. A isto Watanabe chama de litigiosidade contida, conflitos sociais existentes, considerados de menor importância, e sem apreciação (ou de apreciação ineficaz) por parte do Poder Judiciário. Para este jurista, estes Juizados objetivam transformar esta realidade, resgatando a credibilidade da instituição principalmente nas classes de menor poder econômico.

Nesta mesma obra, o texto de João Piquet Carneiro, ex-SecretárioExecutivo do Programa Nacional de Desburocratização, indica a grande influência exercida pelas Small Claim Courts da Cidade de Nova Iorque na criação deste novo procedimento.

Quando em exercício do cargo de Secretário-Executivo do Ministério da Desburocratização, Carneiro conheceu em 1980 esta experiência. Criados em 1934, esses juizados de pequenas causas nova-iorquinos expandiram-se e passaram a fazer parte da estrutura do sistema judiciário daquele Estado. Em seu início, o objetivo era julgar causas dos pequenos comerciantes, mas, com o advento do Estado de Bem Estar, esses tribunais passaram a dedicar-se aos conflitos dos cidadãos comuns. Para Carneiro (1985), um dos grandes sucessos dessa experiência deve-se à quebra do exclusivismo dos juizes na condução das causas com a presença dos árbitros, advogados reconhecidos e que contam com apoio da Bar Association (paralelo da Ordem dos Advogados do Brasil nos EUA). A estrutura leve e a simplificação dos procedimentos, bem como a conciliação levada à cabo pelos árbitros, atuaram de forma decisiva no êxito desta experiência.

Alguns aspectos preliminares devem ser considerados na análise do papel desses órgãos na criação dos Juizados brasileiros. Primeiro, podemos considerar que existem duas grandes "famílias", ou ramos do direito em vigência nos diversos países do mundo: a Civil Law e a Common Law. A primeira, vigente no Brasil, é de origem romano germânica, caracterizando-se por um direito codificado, estruturado e de maior disseminação nos países de origem latina. A Common Law caracteriza-se como um sistema baseado nos antecedentes das decisões dos tribunais como fontes principais de critérios para decisões futuras, sem maiores codificações ou legislações extensas; sua principal influência ocorre nos países de cultura inglesa, como nos EUA.

Em segundo lugar, podemos considerar que o processo de implementação dos Juizados encontrou no Brasil uma resistência de associações como a OAB, dada a não necessidade de advogados no julgamento das causas desse novo

participantes desta construção, assumindo o Poder Executivo papel fundamental na condução do processo de implementação do sistema. 
procedimento, o que era visto por parte de seus membros como grande perda de parte do mercado de atuação profissional e como desproteção das partes menos favorecidas envolvidas em litígio.

Não podemos indicar uma transposição pura e simples do modelo nova-iorquino, mas sim uma grande influência deste como um procedimento de solução de conflitos rápido, barato e informal, e como afirma Lagrasta (1985), houve uma hibridação dos modelos da Common Law e da Civil Law na gestação deste novo sistema no Brasil. Gestação que implicou num amplo debate de associações e representantes das classes jurídicas em torno do tema, fixando as suas principais linhas de efetivação ${ }^{7}$, bem como em uma das mais efetivas ações do Brasil acompanhando os movimentos de garantia do acesso à justiça indicados no Projeto de Florença.

A constitucionalização do tema foi essencial para a sua consolidação e expansão, e a Constituição Federal de 1988 menciona os Juizados em seu art. 24, inciso X, e determina a criação dos Juizados Especiais no inciso I do art. 98. Depois de sete anos, houve a promulgação da Lei 9.099/95, que cria a denominação Juizados Especiais, em substituição aos Juizados de Pequenas Causas e regulamenta o procedimento desses órgãos.

Segundo Vianna et alli (1999, pp. 167 a 186), a democratização do acesso à Justiça no Brasil, na criação de microssistemas especiais como os Juizados Especiais Cíveis, tem como ênfase a conciliação, amparada pelo recurso automático à audiência de julgamento; restrição à competência de Juizados Especiais para o recebimento de ações de pessoas jurídicas, não-obrigatoriedade de representação por advogado perante determinados procedimentos; ampliação dos poderes do juiz sobre o andamento do processo, acompanhada de uma maior responsabilidade das partes.

A Lei 9.099/95, instituiu, além dos Juizados Especiais Cíveis, os Juizados Especiais Criminais, para o processamento e julgamento de infrações penais de menor potencial ofensivo (contravenções penais e crimes cuja lei não comine pena máxima inferior a um ano $)^{8}$. Além das esferas cível e penal da Justiça dos Estados, os microssistemas especiais expandiram-se para a Justiça Federal, por meio dos Juizados Especiais Federais contemplados na Lei $\mathrm{n}^{\circ} 10.259 / 01$, competentes para julgar causas de valor de até 60 salários mínimos.

\footnotetext{
${ }^{7}$ Para uma análise deste debate e de suas articulações, ver Cunha (2004) pp. 19 a 51

${ }^{8}$ Para uma análise do sistema dos Juizados Especiais Criminais ver Grinover et alli (1996).
} 
Os Juizados Especiais Cíveis estaduais têm como principais características o processamento e julgamento de causas de menor complexidade (assim consideradas as arroladas nos incisos e parágrafos de seu art. $3^{\circ}$ ). O processamento das causas tem como critérios orientadores a "oralidade, simplicidade, informalidade, economia processual e celeridade, buscando sempre que possível a conciliação ou transação” (art. $2^{\circ}$ ).

Sua competência restringe-se a causas que não ultrapassem 40 salários mínimos, ações de despejo para uso próprio e ações possessórias cujo objeto não tenha valor superior ao teto fixado de 40 salários. Bem como os JEC's são competentes para executar os seus julgados e títulos extra-judiciais até o teto do valor fixado para todas as suas ações. Interessante notar que os antigos Juizados de Pequenas Causas não possibilitavam a execução de seus julgados, restando ao vencedor da ação de conhecimento ou ao lesado nos casos de acordos firmados mas descumpridos, ingressar no juízo comum para satisfazer a sua pretensão.

Podem ser autores nesse procedimento pessoas físicas e microempresas, estas incluídas posteriormente em modificação da Lei no ano de 1998. São vedados como reclamados o incapaz, o preso, as pessoas jurídicas de direito público, as empresas públicas da União, a massa falida e o insolvente civil.

O juiz, nesta forma de procedimento, é dotado de uma maior liberdade, não sendo necessário que sua decisão restrinja-se aos parâmetros legais, podendo adotar "em cada caso a decisão que julgar mais justa e equânime, atendendo aos fins sociais da lei e às exigências do bem comum”(art. $6^{\circ}$ ).

O procedimento não exige a presença de advogado representando a parte nas causas que não ultrapassem o valor de 20 salários mínimos, a não ser que a parte contrária esteja representada, ou para recorrer das decisões tomadas pelo juiz.

O princípio da oralidade informativo da Lei realiza-se em duas audiências. A primeira, de conciliação, não necessita ser conduzida pelo juiz, mas por conciliadores (que em realidade são ou estudantes de direito, advogados ou funcionários do cartório) sob sua orientação.

Acerca dos conciliadores, cabe ressaltar que a pesquisa realizada pelo Centro Brasileiro de Estudos e Pesquisas Judiciais - CEBEPEJ, em 2003, indicou que 47,7\% dos conciliadores entrevistados no Estado de São Paulo são advogados, e 38,8\% são estudantes de direito. E, apesar da essencialidade da sua função, ao aproximar as partes e possibilitar uma solução do litígio mais rápida e menos custosa para os demandantes e para o 
Estado, esta mesma pesquisa indicou que apenas $26,5 \%$ dos conciliadores haviam passado por algum curso de formação ou aperfeiçoamento.

Caso esta audiência de conciliação não resulte em acordo, é designada audiência de instrução e julgamento para a oitiva de testemunhas e apresentação de demais provas, bem como para a decretação de sentença.

Havendo necessidade de recorrer da sentença, a parte deverá contratar advogado e recolher as custas, sendo que a sucumbência no recurso implica no pagamento dos custos processuais, deixando de existir a gratuidade do procedimento. Ponto interessante quando se trata de recursos nos Juizados é que o mesmo não é dirigido a instância superior, como Tribunais de Justiça. Quem julga os recursos são juízes de primeiro grau atuantes nos próprios JEC’s reunidos nos chamados Colégios Recursais.

A ampliação do acesso à Justiça neste modelo é de certa forma realizada, na medida em que, por não haver a exigência do recolhimento de custas judiciais, nem a necessidade de que a parte esteja representada por um advogado, a população tem os custos de acesso a uma decisão de seus litígios pelo Poder Judiciário reduzidos. Devemos também considerar as diversas associações e convênios realizados pelo Poder Judiciário para a expansão deste sistema em locais que não somente os tradicionais fóruns, fato exposto mais adiante neste capítulo.

A Tabela 01 demonstra o crescimento quantitativo e percentual relativo desse procedimento diante dos demais ritos adotados pelo Poder Judiciário no Estado de São Paulo:

Tabela 01: Tipos de Ação Distribuída por Ano nas Varas da Primeira Instância do Poder Judiciário do Estado de São Paulo - Número e Percentual

\begin{tabular}{ccccccccccc}
\hline $\begin{array}{c}\text { Tipo de } \\
\text { Ações }\end{array}$ & \multicolumn{1}{c}{1999} & \multicolumn{2}{c}{2000} & \multicolumn{2}{c}{2001} & \multicolumn{2}{c}{2002} & & 2003 \\
\hline \hline & $\mathrm{N}$ & $\%$ & $\mathrm{~N}$ & $\%$ & $\mathrm{Não}$ & $\%$ & $\mathrm{~N}$ & $\%$ & $\mathrm{~N}$ & $\%$ \\
Cíveis & 1.784 .955 & 39,92 & 1.798 .479 & 40,51 & 1.692 .318 & 38,41 & 2.066 .676 & 39,94 & 2.183 .417 & 37,35 \\
JECíveis & $\mathbf{2 7 5 . 1 3 0}$ & $\mathbf{6 , 1 5}$ & $\mathbf{3 3 5 . 4 1 8}$ & $\mathbf{7 , 5 5}$ & $\mathbf{3 8 2 . 3 9 7}$ & $\mathbf{8 , 6 8}$ & $\mathbf{4 7 1 . 4 6 9}$ & $\mathbf{9 , 1 1}$ & $\mathbf{9 0 8 . 0 2 5}$ & $\mathbf{1 5 , 5 3}$ \\
Ex. Fiscal & 1.264 .397 & 28,28 & 1.241 .840 & 27,97 & 1.327 .078 & 30,12 & 1.532 .474 & 29,62 & 1.562 .817 & 26,74 \\
Criminais & 602.246 & 13,47 & 547.991 & 12,34 & 529.610 & 12,02 & 564.454 & 10,91 & 608.674 & 10,41 \\
JECriminais & 349.660 & 7,82 & 329.882 & 7,43 & 303.507 & 6,89 & 357.997 & 6,92 & 385.114 & 6,59 \\
Infância & 194.859 & 4,36 & 186.469 & 4,20 & 171.285 & 3,89 & 181.319 & 3,50 & 197.064 & 3,37 \\
Total & $\mathbf{4 . 4 7 1 . 2 4 7}$ & $\mathbf{1 0 0 , 0 0}$ & $\mathbf{4 . 4 4 0 . 0 7 9}$ & $\mathbf{1 0 0 , 0 0}$ & $\mathbf{4 . 4 0 6 . 1 9 5}$ & $\mathbf{1 0 0 , 0 0}$ & $\mathbf{5 . 1 7 4 . 3 8 9}$ & $\mathbf{1 0 0 , 0 0}$ & $\mathbf{5 . 8 4 5 . 1 1 1}$ & $\mathbf{1 0 0 , 0 0}$ \\
\hline \hline
\end{tabular}

Fonte: Tribunal de Justiça do Estado de São Paulo, Relatório Anual de Gestão 2003. 
Nos quatro anos indicados, a participação do Juizado Especial Cível no total de feitos distribuídos cresceu de 6,6\% em 1999 para 15,53\% em 2003, passando de 275.130 feitos distribuídos para 908.025.

Os números do movimento dos Juizados Especiais para a capital de São Paulo no mesmo período, bem como sua participação percentual no movimento de todos as ações da comarca e do Estado, são indicados na Tabela 02.

Tabela 02: Feitos Distribuídos nos Juizados Especiais Cíveis da Comarca de São Paulo Número e Percentual

\begin{tabular}{cccccc}
\hline \hline Ano & 1999 & 2000 & 2001 & 2002 & 2003 \\
\hline $\begin{array}{c}\text { Ações dos } \\
\text { JEC's }\end{array}$ & 56.498 & 69.564 & 93.148 & 101.892 & 105.298 \\
$\begin{array}{c}\text { \% em relação } \\
\text { à Capital }\end{array}$ & 4,84 & 6,00 & 8,51 & 8,83 & 9,00 \\
$\begin{array}{c}\% \text { em relação } \\
\text { ao Estado }\end{array}$ & 1,26 & 1,57 & 2,11 & 1,97 & 1,80 \\
\hline \hline
\end{tabular}

Fonte: Tribunal de Justiça do Estado de São Paulo, Relatório Anual de Gestão 2003.

Observamos que o movimento dos juizados da capital também cresceu no mesmo período. De 56.498 processos em 1999 passaram para 105.298 em 2003, aumento de 86,3\%. A participação percentual destes feitos na capital também apresenta acréscimo, de 4,8\% para 9\% do total de feitos distribuídos em São Paulo. A sua participação no Estado cresceu entre o primeiro e o último ano da série, de 1,3\% para 1,8\%; porém esta tendência para a Unidade Federativa não foi tão constante como no caso da Comarca, atingindo o maior valor de participação proporcional em 2001 (2,1\%), decrescendo nos dois anos seguintes da série.

Na cidade de São Paulo, as experiências dos Juizados tiveram seu início em 1986, com a instalação de um Juizado Informal de Conciliação no fórum da Lapa. Atualmente a comarca conta com atendimento, nos moldes da Lei 9.099/95, em 11 Fóruns Regionais e no Juizado Especial Cível Central. Um grande fator de expansão dos Juizados em São Paulo foi a associação do Tribunal de Justiça com as faculdades de direito para a criação de anexos.

Conforme Cavalcante (2001), a iniciativa de instalar anexos de Juizados Especiais em faculdades, além de expandir a prestação jurisdicional nos moldes apregoados pela Lei 9.099/95, revela-se de extrema importância para a formação prática dos 
estudantes de cursos de direito, e também contribui para o ideal de integração entre universidade e comunidade.

Esse tipo de associação entre o Poder Judiciário e faculdades teve o seu auge na cidade de São Paulo nos anos de 1999 e 2000. Entre os meses de março e dezembro de 1995 foram instalados Juizados anexos em 20 universidades, e em 2000 a fórmula foi expandida para mais seis universidades.

Esses anexos têm competência para toda a matéria prevista na Lei 9.099/95, e contam com os seguintes atores: alunos-conciliadores, professores-orientadores, juizes, funcionários do fórum e advogados. O contrato de convênio estipula que os juizes a atuarem nos Juizados anexos serão designados pelo Conselho Superior da Magistratura, e os conciliadores serão indicados, selecionados e nomeados por ato de juiz diretor do JEC. O Tribunal de Justiça ainda tem como função designar um escrevente técnico judiciário e um oficial de justiça. A Universidade tem como obrigação fornecer o pessoal de apoio técnico para o anexo, bem como docentes e discentes para o atendimento à população; destinar o espaço físico, mobiliário e equipamento de informática para o seu funcionamento; bem como um terminal de telefone ou um ramal para uso exclusivo do Juizado.

Podemos afirmar, juntamente com Cavalcante (2001, pp. 142 e 143), que esses convênios atingem sua dupla finalidade, de ampliar o atendimento jurisdicional à população em geral e de integrar os alunos ao universo prático do direito. Isto ocorre no bojo de uma típica associação entre o poder público e as organizações da sociedade civil, por meio da convergência dos interesses de ambos: ampliação da prestação jurisdicional e capacitação técnica dos alunos.

Em São Paulo, há também um Juizado Especial instalado no Poupatempo Itaquera. A instalação de Juizados em Postos de Atendimento do Poupatempo também indica a variabilidade que o sistema vem adquirindo na extensão dos seus projetos de acesso à justiça. Os Poupatempo são conhecidos como locais de concentração de diversos serviços prestados principalmente pelo Poder Público estadual, tais como confecção de RG, carteira de habilitação, documentação de veículos, atendimento da CDHU, posto policial, etc. Observa-se que este mesmo local, na região mais populosa de São Paulo, zona leste, agora também conta com o atendimento dos Juizados Especiais. Outra grande experiência de ampliação dos juizados é a instalação dos Juizados nos quatro CIC's da capital. Este tipo de associação entre o Judiciário e o Poder Executivo será analisado quando tratarmos dos objetos de nossa pesquisa de campo no Capítulo 3 da presente dissertação. 
Ainda existem mais duas experiências de ampliação do acesso à justiça em São Paulo: os Juizados Itinerantes e o Expressinho. Os Juizados itinerantes foram criados em 1998, e, no ano de 2003, a pesquisa realizada pelo Centro Brasileiro de Estudos e Pesquisas Judiciais - CEBEPEJ, identificou 39 juizados itinerantes funcionando em cidades do interior do Estado. Estes Juizados são estruturas montadas em trailers que circulam em bairros distantes dos centros das cidades, realizando o atendimento e registro das reclamações, bem como audiências de conciliação e de instrução e julgamento. As execuções de seus julgados, entretanto, são feitas nos fóruns conforme a região competente.

O “Expressinho” instalado no Juizado Especial Cível Central em São Paulo teve origem na experiência do Estado do Rio de Janeiro. Este instituto caracteriza-se pela atuação pré-processual do órgão Judiciário que, em convênio com empresas privadas, notadamente concessionárias de serviços públicos, aproxima a parte reclamante da reclamada para a obtenção de acordo. Neste procedimento, o reclamante registra, via internet, a sua reclamação, que é enviada pelo Juizado à empresa conveniada. Marca-se a data de uma audiência, sem caráter judicial, para a obtenção ou não do acordo. Caso não haja sucesso, a reclamação é então registrada como inicial do processo do JEC, e segue o trâmite normal.

Tanto no Estado do Rio de Janeiro, quanto em São Paulo, esta tentativa de aproximação pré-processual das partes foi motivada pela existência de grande número ações contra os mesmos reclamados nos Juizados, com grande destaque para as empresas prestadoras de serviço público. Para termos uma idéia, no Rio de Janeiro a experiência iniciou-se com a Telemar, concessionária de telefonia fixa, e, em São Paulo, as entidades conveniadas são prestadoras de serviço de telefonia, água e esgoto e energia elétrica, havendo apenas um banco privado que foi recentemente descredenciado.

A Tabela 03 abaixo indica o número de reclamações, audiências e acordos do “Expressinho” no período de Janeiro ao final de Agosto de 2005: 
Tabela 03: Reclamações, Acordos, Ausências e Audiências no Sistema Expressinho do Juizado Especial Cível Central da Comarca de São Paulo de 02/01/2005 a 31/08/2005 Número e Percentual

\begin{tabular}{ccccccc}
\hline \hline $\begin{array}{c}\text { Empresa } \\
\text { Reclamada }\end{array}$ & Telefônica & Sabesp & Eletropaulo & Embratel & Unibanco & Total \\
\hline $\begin{array}{c}\text { Total de } \\
\text { Reclamações }\end{array}$ & 163 & 52 & 204 & 14 & 4 & 437 \\
$\quad$ Com & 132 & 28 & 141 & 7 & 4 & 312 \\
$\begin{array}{c}\text { Acordos } \\
\text { Sem }\end{array}$ & 21 & 17 & 51 & 3 & 0 & 92 \\
$\begin{array}{c}\text { Acordos } \\
\text { Reclamante } \\
\text { Ausente }\end{array}$ & 10 & 2 & 10 & 1 & 0 & 23 \\
$\begin{array}{c}\text { Reclamado } \\
\text { Ausente }\end{array}$ & 0 & 5 & 1 & 3 & 0 & 9 \\
$\begin{array}{c}\text { Reclamações } \\
\text { Canceladas } \\
\text { Total de }\end{array}$ & 0 & 0 & 0 & 0 & 0 & 0 \\
$\begin{array}{c}\text { Audiências } \\
\text { \% Real de } \\
\text { Acordos }\end{array}$ & 86,27 & 62,22 & 73,44 & 70,00 & 100,00 & 77,23 \\
\hline \hline
\end{tabular}

Fonte: Cartório do Juizado Especial Cível Central de São Paulo

Apesar do pequeno número de audiências realizadas ante os números totais de feitos dos Juizados de São Paulo, há um grande percentual de acordos: 77,23\% das audiências resultaram em acordo que retiraram processos dos JEC's. Observa-se também que em todas as empresas conveniadas o percentual de acordo é maior que $50 \%$, ou seja, mais da metade das reclamações movidas contra essas empresas por meio do "Expressinho" não se transformaram em feitos judiciais.

A necessidade de criação deste novo tipo de tentativa de acordo nasceu do diagnóstico da presença constante de prestadores de serviço público como reclamados nos processos dos Juizados. Esta é a hipótese principal que procuramos analisar no decorrer da presente dissertação. Para tal, no próximo capítulo trataremos de dois fundamentos principais que podem ser aventados como premissas teóricas a explicar essa observação tanto dos operadores do direito quanto das pesquisas acerca do tema acesso à justiça: o processo de privatização e regulação das empresas prestadoras de serviços públicos e as regras de proteção dos consumidores. 


\section{Capítulo 02 - Os Serviços Públicos como Questão dos Juizados Especiais}

O objetivo do presente capítulo é analisar os Juizados Especiais Cíveis em face das reformas administrativas recentes e da criação de leis de defesa do consumidor, bem como apresentar uma breve revisão bibliográfica e de pesquisas e levantamentos anteriores sobre a demanda desta nova forma de acesso à justiça, levando em conta a questão dos tipos de ação e reclamados participantes de seus processos. Deste modo, procuramos a partir dessas fontes, subsídios para fixar as principais hipóteses de análise dos resultados da pesquisa levada a cabo em três JEC's da Comarca de São Paulo.

Em um primeiro momento discutiremos a mudança do papel do Estado brasileiro nos anos 90, principalmente o processo de delegação dos serviços públicos para entes privados. Após, realizaremos uma breve discussão sobre os principais dispositivos do Código de Defesa do Consumidor, documento legal que viabiliza a propositura de ações contra produtores, fornecedores e distribuidores de produtos e serviços, sejam estes públicos ou não.

Em seguida trataremos brevemente sobre os resultados de pesquisas e levantamentos anteriores que apontam para a presença de demandas sobre serviços públicos nos Juizados Especiais, procurando demonstrar a presença nos mesmos das questões de consumo e de prestação dos serviços públicos.

\subsection{A Prestação de Serviços Públicos após a Reforma do Estado Brasileiro}

Para Majone (1997) as modernas teorias político-econômicas distinguem três tipos de intervenção pública na economia: redistribuição das rendas, estabilização macroeconômica e regulação do mercado. O primeiro refere-se às transferências de recursos de um grupo, região ou país para outro, bem como a provisão de bens meritórios (educação básica, seguridade social etc). O segundo refere-se às tentativas de alcance e sustentabilidade de níveis satisfatórios de crescimento econômico e emprego. E o terceiro 
tipo tem como objetivo a correção de diversos tipos de falhas de mercado, como monopólios naturais, externalidades negativas, informações incompletas e provisão insuficiente de bens públicos. Os Estados utilizam-se desses três modelos, cuja importância relativa varia de país a país e de um período histórico a outro.

No Brasil, os anos noventa trouxeram um novo conceito de regulação pública da economia, que procurou privilegiar o terceiro modelo descrito. O texto base dessa reforma foi o Plano Diretor da Reforma do Estado, desenvolvido pelo então recém criado Ministério da Administração e Reforma Econômica ${ }^{9}$. Tal projeto procurou delimitar o papel, redefinir a atuação reguladora e aumentar a governança (capacidade de gerir a máquina pública e implementar políticas) e a governabilidade (capacidade de enfrentar desafios e oportunidades) do Estado ${ }^{10}$. Apesar das diversas explicações acerca das razões do movimento reformista dos anos $90^{11}$ e sobre suas dificuldades políticas de implementação ${ }^{12}$, tais transformações retiraram o Estado da maioria de suas funções produtivas diretas com a privatização de empresas públicas, e trouxeram importantes mudanças nas atividades regulatórias do mesmo.

Nascimento (2003) afirma que nesse processo de reforma do Estado brasileiro houve uma inversão de prioridades na construção do modelo regulatório nacional. A reforma foi pensada em termos gerenciais, mas realizada com o objetivo principal de sanar o deficit fiscal do Estado. Indica a autora que há uma falha relevante: "não houve uma consolidação do marco institucional no processo de reestruturação do Estado brasileiro, no que tange à privatização no setor de infra-estrutura"(Nascimento 2003, p. 188). Este fato faz com que o nosso atual modelo tenha uma série de problemas que impedem a realização do principal objetivo da reestruturação do Estado brasileiro da produção para a regulação.

Melo (2000, p.23), apoiado em Levy e Spiller, indica a existência de um quadro de referências centrado basicamente em três aspectos ou dimensões para a análise da política regulatória: restrições relativas à ação discricionária por parte do regulador, restrições formais e informais relativas à mudança de regime regulatório, e instituições que

\footnotetext{
${ }^{9}$ O Ministério da Administração e Reforma do Estado foi comandado pelo então ministro Luiz Carlos Bresser Pereira e ao final foi incorporado pelo Ministério do Planejamento. Uma análise de sua atuação e das mudanças por ele implementadas pode ser encontrada em Bressan (2002).

${ }^{10}$ Ministério da AdministraÇÃo e Reforma do Estado, Plano Diretor da Reforma do Estado, Brasília, 1995.

${ }^{11}$ A análise dos diversos modelos interpretativos da reforma pode ser encontrada em Velasco e Cruz (1998). Os motivos dessa reforma como um caminho para a superação da crise que vivia o Estado brasileiro pode ser encontrada em Diniz (1998) e também em Pereira (1998).

${ }^{12}$ Para uma análise dos problemas de implementação das reformas administrativas como problemas de coordenação e de ação coletiva, ver Rezende (2002a e 2002b).
} 
garantem esse conjunto de restrições. Tal quadro tem como premissa a ausência de um desenho regulatório ótimo padrão, mas uma gama de alternativas que variam conforme o contexto institucional de cada país.

Há um grau de consistência entre governança regulatória e os incentivos regulatórios. A primeira indica o conjunto de mecanismos que uma determinada sociedade utiliza para a restrição da amplitude da ação discricionária dos órgãos reguladores e para a resolução de conflitos daí resultantes. A estrutura de incentivos regulatórios abarca o conjunto de instrumentos de regulação microeconômica, tais como as regras de formação de tarifas, seus reajustes e subsídios cruzados, de competição e entrada, conectividade entre provedores de serviço etc.

A estrutura de incentivos regulatórios depende fundamentalmente da estrutura de governança regulatória. Ambas variam conforme a escolha dos reguladores, mas sofrem importantes restrições da estrutura institucional do país. Assim, o autor indica que tal estrutura, conforme a literatura neo-institucionalista, compõe-se das instituições do Legislativo, Executivo e Judiciário, de regras informais que são tacitamente aceitas pelos atores sociais e da capacidade institucional do país.

Esta estrutura institucional irá influir na criação e desempenho do movimento indicado por Majone (1997, p.6) de privatização, liberalização e, principalmente, desregulação/re-regulação em um nível diverso de governança. Tal movimento baseia-se na necessidade de, ao se retirar o Estado da prestação direta de serviços públicos, dotá-lo de instrumentos flexíveis a impor uma estrutura planejada na economia e, ao mesmo tempo, proteger o interesse público dos interesses de grupos privados poderosos.

Este movimento, condicionado pela estrutura institucional do país, provoca, diante das necessidades apontadas, a passagem da burocracia centralizada para o modelo de regulação. Esta passagem ocorre principalmente em setores econômicos em que expertise e reputação são chaves para uma alta efetividade.

A delegação de instrumentos de política pública para órgãos burocráticos insulados nos coloca diante do problema da responsividade e responsabilização desses órgãos ${ }^{13}$, bem como diante das diversas formas de controle que se possa exercer

\footnotetext{
${ }^{13}$ Para uma análise do déficit democrático das agências, ver Melo (2001).
} 
perante a sua atuação ${ }^{14}$. O controle judicial é apontado como um meio de garantia de sua efetividade e de manutenção das premissas desse novo papel do Estado.

O controle judicial, posto como um controle contramajoritário que determina the rule of the law ${ }^{15}$ é conceituado como a-político e reativo aos interesses a ele submetidos. Mas o papel exercido sobre a conduta de personagens envolvidos em questões de políticas públicas vai além disso.

O Poder Judiciário, considerando as suas atribuições, dispostas pela Constituição Federal de $1988^{16}$, tem no art. $5^{\circ}$, XXXV do mesmo diploma, que dispõe "a lei não excluirá da apreciação do Poder Judiciário lesão ou ameaça a direito", uma ilimitada abertura para a sua atuação.

Inserido na teoria de tripartição de poderes ${ }^{17}$, conforme a estrutura constitucional, o Poder Judiciário atinge, em sua atuação, esferas de controle do Poder Executivo em muitas ocasiões ${ }^{18}$.

Do mesmo modo, o modelo regulatório, com pretensões de isolar-se da atuação judicial, frente às exigências econômicas, a falta de conhecimentos técnicos suficientes para decidir as questões, bem como a falta de sigilo necessário em casos empresariais $^{19}$, mantém ainda relações com a estrutura de atuação do órgão julgador.

Conforme Marques Neto (2000), o controle judicial é “indesviável”. Parte o autor do pressuposto que a atividade regulatória é atividade típica do Poder Público, balizada nos princípios gerais do Direito Público, subordinando-se ao controle judicial até mesmo como forma de garantia do Estado Democrático de Direito.

Podemos delinear a atuação judicial em nossa realidade de política regulatória com base em dois pontos. Primeiro podemos considerar como Majone (1997, p. 21), que as reformas regulatórias provocam uma realocação do poder entre antigos atores. Neste ponto, o Judiciário assume um papel de relativa neutralidade para uma prática ativa no

\footnotetext{
${ }^{14}$ Para os diversos tipos de controle que existem entre governos e burocracias ver Przeworski (2003), especialmente o Capítulo 7 Politicians and bureaucrats: Oversight.

${ }^{15}$ Sobre o conceito de poder contramajoritário e Judiciário, verPrzeworski (2003, especialmente p.140 a 143).

${ }^{16}$ A Constituição Federal de 1988 dedica o Capítulo III ("Do Poder Judiciário"), do Título IV ("Da

Organização dos Poderes") a esta instituição. Mas a sua estrutura, considerando essas normas como diretrizes, não se esgota nestas. A análise da estrutura judicial brasileira é encontrada em Rodrigues (2003); para uma análise da evolução da instituição temos Sadek (1995).

${ }^{17}$ Uma análise do papel do Judiciário frente a uma atual interpretação da tripartição dos poderes é feita por Ferraz Jr. (1994).

${ }^{18}$ Como análise dessa "extensão” do Poder Judiciário na esfera de competência de outros poderes temos Arantes (1997), que analisa o controle de constitucionalidade exercido pelos Tribunais Superiores. E, do mesmo modo, centrado na figura do STF, temos Vieira (1994).

${ }^{19}$ A análise entre o Poder Judiciário e a economia no Brasil é feita na coletânea organizada por Castelar (2000).
} 
jogo administrativo. Destaca o autor o envolvimento das cortes na administração e políticas públicas, tornando-se talvez uma das mais importantes conseqüências do crescimento do Estado regulador.

Deste modo, delineia-se a primeira relação: o Judiciário como canal de atuação dos poderes de governo sobre a sua burocracia. Isto ocorre porque a administração, antes direta e com uma estrutura hierárquica interna, continha os seus canais próprios de resolução de conflitos. Ao passarmos para as relações contratuais entre os governantes e a burocracia do Estado regulador, onde há uma maior independência hierárquica, tais canais não mais se ofertam. $\mathrm{O}$ que antes era um conflito interno, externaliza-se, levando às portas judiciais essa relação. Neste ponto o Judiciário assume uma das mais importantes funções ao transformar-se no locus de resolução dos conflitos entre Governo e burocracia, com suas decisões transformadas em regras de relação dos atores.

O segundo ponto da relação refere-se aos interesses dos consumidores dos serviços públicos sob a regulação do Estado. Neste ponto encontramos a influência de políticas de acesso à Justiça nesta relação Consumidor-Judiciário-Políticas Públicas, transformando a atividade judicial em um canal privilegiado na resolução de litígios entre esses atores. A presente dissertação tem como objetivo explorar uma parte desse segundo ponto, para verificar se estes consumidores, diante da redução de custos e aumento das possibilidades com as práticas de garantia do acesso à justiça, utilizam-se da nova estrutura dos Juizados para a garantia de seus direitos.

O processo de privatização e delegação da prestação dos serviços públicos foi de fundamental importância para permitir que cidadãos ingressem nos Juizados Especiais, pois, por força do art. $8^{\circ}$ da Lei 9.099/95, estes não aceitam como partes de seus processos as pessoas jurídicas de direito público, o que não permite o questionamento nos JEC's das as atividades prestadas diretamente pela estrutura administrativa do Estado, mas somente a propositura de ações contra empresas concessionárias.

O processo de reforma do Estado brasileiro concorreu para um maior questionamento das políticas e serviços públicos, ao colocá-los em destaque no cenário político e social. A literatura acima apontada soma tal fato à indefinição regulatória de um processo que visou, antes da tão propalada eficiência dos serviços públicos, o saneamento das dívidas do Estado. A profusão de regras e critérios que permeiam as atividades públicas concedidas permite o questionamento em juízo de quase todo o processo público entre o prestador e o cidadão. Mauro Cappelletti (1999, p.20) afirma que: 
“... a expansão do direito legislativo, no Estado moderno é estendida

a muitíssimos domínios antes ignorados pela lei, acarretou e ainda

está acarretando consigo a paralela expansão do direito judiciário”

O Estado brasileiro, ao delegar e assumir a regulação de atividades econômicas antes prestadas diretamente criou, e ainda cria, regras e critérios, expandindo sua atuação, não só administrativa, mas também legislativa e principalmente judiciária, a campos para os quais não se imaginava a duas décadas atrás, como, por exemplo, no caso da cobrança de assinatura nos serviços telefônicos.

A este maior regramento de atividades reguladas, soma-se a existência de regras e princípios característicos do Estado de Bem Estas consagrados em diplomas legais, como as normas do direito do consumidor, assunto tratado no próximo item.

\subsection{O Direito do Consumidor}

De acordo com obra dos autores do anteprojeto do Código de Defesa do Consumidor, Lei 8.078/90, o homem moderno vive em função de um modelo de associativismo que se impôs no século XX: a sociedade de consumo, caracterizada por um número crescente de produtos e serviços, pelo domínio do crédito e do marketing, assim como pela dificuldade de acesso à justiça. A necessidade de se elaborar um código de proteção ao consumidor parte do diagnóstico de que, neste novo modelo de associativismo, a posição do consumidor piorou ao invés de melhorar:

"Se antes consumidor e fornecedor encontravam-se em uma situação de relativo equilíbrio de poder de barganha (até porque se conheciam), agora é o fornecedor (fabricante, construtor, importador ou comerciante) que, inegavelmente, assume a posição de força na relação de consumo e que, por isso mesmo 'dita as regras’.”(Grinover et alli 2001, p. 6) 
Esta situação exige dos poderes do Estado a edição, regulamentação e aplicação de normas imperativas de controle do relacionamento consumidor-fornecedor. Este é o chamado intervencionismo estatal, já existente em sociedades de capitalismo avançado, como Estados Unidos e países europeus. A opção brasileira para a edição destas normas foi de inserí-las em um sistema, com a concatenação de regras e princípios gerais para a proteção estatal do pólo hipossuficiente das relações de consumo. O resultado foi a Lei 8.078/90, o Código de Defesa do Consumidor. Deste Código iremos tratar brevemente sobre dois tipos de normas: as atinentes à prestação de serviços públicos e as normas que garantem o acesso do consumidor à justiça, notadamente às que se referem direta ou indiretamente aos Juizados Especiais.

Com relação à prestação de serviços públicos, esta é abarcada pela norma genérica de definição do que são relações de consumo. De acordo com o Código de Defesa do Consumidor, as relações de consumo são compostas pelo consumidor e fornecedor. A definição do primeiro está no art. $2^{\circ}$ :

"Consumidor é toda a pessoa física ou jurídica que adquire ou utiliza produto ou serviço como destinatário final”

E as definições de fornecedor, produto e serviço estão no art $3^{\circ}$ :

“Fornecedor é toda a pessoa física ou jurídica, pública ou privada, nacional ou estrangeira, bem como os entes despersonalizados, que desenvolvem atividades de produção, montagem, criação, construção, transformação, importação, exportação, distribuição ou comercialização de produtos ou prestações de serviços.

$\$ 1^{\circ}$ Produto é qualquer bem, móvel ou imóvel, material ou imaterial. $\S 2^{\circ}$ Serviço é qualquer atividade fornecida no mercado de consumo, mediante remuneração, inclusive as de natureza bancária, financeira, de crédito e securitária, sla as decorrentes das relações de caráter trabalhista."

Observa-se que, para fins deste Código, é considerado fornecedor o responsável por colocar bens e serviços ao consumidor, pouco importando a natureza do 
próprio, excetuando-se apenas a natureza trabalhista de relação. Assim, as normas dispostas neste documento legal aplicam-se totalmente às relações decorrentes da prestação de serviço público.

$\mathrm{O}$ art. $4^{\circ}$, em seu inciso VII, indica como princípio da Política Nacional das Relações de Consumo estatuída pelo Código a "racionalização e melhoria dos serviços públicos”.

$\mathrm{O}$ inciso $\mathrm{X}$ do art. 6 do mesmo Código estatui que um dos direitos básicos do consumidor é a “adequada e eficaz prestação dos serviços públicos em geral”.

E, ainda sobre a prestação de serviços públicos, o art. 22 e seu parágrafo único do Código dispõem que:

“Art. 22 - Os órgãos públicos, por si ou suas empresas, concessionárias, permissionárias ou sob qualquer outra forma de empreendimento, são obrigados a fornecer serviços adequados, eficientes, seguros e, quanto aos essenciais, contínuos. Parágrafo único - Nos casos de descumprimento, total ou parcial, das obrigações referidas neste artigo, serão as pessoas jurídicas compelidas a cumpri-las e a reparar os danos causados, na forma prevista neste Código.”

Deste modo, caracteriza-se totalmente a responsabilidade da prestação dos serviços públicos como uma responsabilidade de relação fornecedor-consumidor, sejam estes serviços prestados pela Administração diretamente ou através de empresas concessionárias.

Com relação aos Juizados Especiais Cíveis e sua relação com o direito do consumidor, Cunha (2004) afirma que a evolução do sistema dos Juizados Especiais acompanhou a evolução da legislação de defesa do consumidor. O Código de Defesa do Consumidor foi discutido no início da década de 80, mesma época de criação e implantação das novas formas de acesso à justiça. Afirma a autora que:

"O desenvolvimento concomitante dos dois institutos fez com que uma das funções do juizado fosse servir de canal para atender as novas demandas que surgiam com a regulação dos direitos do 
consumidor, que por envolverem casos de baixo valor, não chegavam na justiça comum” (pp.94 e 95).

O fato de ambos os sistemas nascerem e se desenvolverem em um mesmo cenário político-histórico pode ser aventada como uma das razões da existência do grande número ações que tenham por objeto as relações de consumo nos Juizados Especiais.

Constata-se que o Código analisado, além de dispor sobre regras materias de regulação da relação de consumo, dispõe também sobre as suas formas de proteção. Dentre essas temos várias alusões a procedimentos judiciais específicos e formas de acesso à justiça. $\mathrm{O}$ art. $5^{\circ}$ dispõe que:

“Art. 5 Para a execução da Política Nacional das Relações de Consumo, contará o Poder Público com os seguintes instrumentos, entre outros:

IV - criação de Juizados Especiais de Pequenas Causas e Varas especializadas para a solução de litígios de consumo;”

Os Juizados Especiais de Pequenas Causas são os já citados da Lei 7.244/84, substituídos em 1995 pelos Juizados Especiais Cíveis. Sobre os mesmos, Filomeno (in Grinover et alli 2000, p. 154) afirma que, se bem estruturados, serão o "grande desaguadouro das questões individuais que afligem ao consumidor”. Estes Juizados aparecem ao lado de outras instituições garantidoras dos direitos do consumidor, como os PROCON’s, Promotorias Especializadas e Assistência Judiciária.

Sobre as "Varas Especializadas", estas não se confundem com os juizados já citados, dado que sua competência de julgamento é exclusivamente de demandas marcadamente coletivas ou de feitos individuais relativos somente às relações de consumo. As capitais de Salvador, Vitória, Aracajú e Maceió já contam com as Varas Especializadas de Interesses Difusos e Coletivos de defesa do consumidor. No Estado de São Paulo foram criadas cinco varas na capital pela Lei Estadual nº 762 de 1994, mas ainda não instaladas.

O Código de Defesa do Consumidor trata do assundo de acesso à justiça no inciso VII de seu art. $6^{\circ}$, ao dispor que é um dos direitos básicos do consumidor: “o acesso aos órgãos judiciários e administrativos, com vistas à prevenção ou reparação de 
danos patrimoniais e morais, individuais, coletivos ou difusos, assegurada a proteção jurídica, administrativa e técnica aos necessitados”

A parte processual do Código do Consumidor, disposta no Título III da Lei sob o título de "Da Defesa do Consumidor em Juízo”, conforme Grinover (in Grinover et alli 2000, p. 215), atua em duas vertentes: ações coletivas e individuais. As primeiras decorrem do tratamento dos direitos de consumo como difusos e coletivos, permitindo que atores legitimados como o Ministério Público e Associações de Defesa do Consumidor ingressem em juízo visando a proteção coletiva de direitos de consumo através da tutela judicial.

Com relação às ações individuais, nosso foco de análise, a Lei facilita o acesso à justiça ao determinar que a competência do lugar com o qual se ingressa com a ação relativa à direito de consumo seja o domicílio do autor - consumidor (art. 101, I). Também são apontados como instrumentos processuais de auxílio ao consumidor para a garantia do acesso à justiça a vedação da denunciação da lide e um novo tipo de chamamento ao processo, em determinadas hipóteses (arts. 88 e 101, II), a previsão de adequada tutela jurisdicional por intermédio de toda e qualquer ação (art. 83), nova configuração de tutela específica, nas ações que tenham por objeto o cumprimento de obrigação de fazer ou não fazer (art.; 84), extensão subjetiva da coisa julgada, apenas para beneficiar as pretensões individuais(art. 103) etc.

Ao tratar da tutela dos consumidores e juizados especiais de causas cíveis de menor complexidade, Watanabe (in Grinover et alli 2000, pp. 345) registra um ponto de preocupação com o futuro desses juizados. Explica o autor que os Juizados Especiais de Pequenas Causas foram criados para propiciar "um acesso mais facilitado à justiça para o cidadão comum, principalmente para a camada mais humilde da população”. O objetivos de tais entidades "jamais foi o de resolver a crise da justiça, sua morosidade e ineficiência na solução dos conflitos”. Aponta o autor que com a Lei 9.099/95 foi ampliada a competência dos Juizados Especiais, sobrecarregando de trabalho os localizados principalmente em centros populosos, como São Paulo. Não houve a contraprestação, conforme o autor, de melhoria de infra-estrutura pessoal e material desses novos juizados, somando-se o pouco entusiasmo e má vontade da cúpula dos Judiciários Estaduais para com os mesmos. Pontua que é cada vez mais crescente a burocratização desses Juizados, com a distribuição de senhas de atendimento, e se prolongando cada vez mais o prazo para efetivo registro da manifestação do autor. Conclui que: 
“À continuidade de semelhante situação, que é de extrema gravidade, a finalidade maior dos Juizados, que é de facilitação do acesso à justiça e de celeridade na solução dos conflitos de interesses, estará irremediavelmente desvirtuada, com o lastimável comprometimento da própria razão de ser desses Juizados. Os que não entenderam a idéia básica dos Juizados procuraram fazer deles uma solução para a crise da justiça, e com isto não somente estão matando os Juizados, como também agravando mais ainda a crise que há muito afeta a nossa justiça."(p.246)

Interessante notar que o autor trata da crise dos Juizados em um texto destinado ao tratamento da proteção do consumidor em juízo, indicando a clara relação próxima entre ambos os institutos.

Portanto, o que quisemos demonstrar, foi a existência de uma proximidade das políticas de relação de consumo, abarcando a prestação de serviços públicos, e das políticas de acesso à justiça, estatuídas ambas no Código de Defesa do Consumidor. Talvez, além da discussão de ambas as políticas ocorrerem na mesma época conforme já salientado, a clara vinculação das políticas de proteção ao consumo com as políticas de acesso à justiça em textos legais como o discutido explique a alta presença de demandas de relações de consumo nos Juizados Especiais Cíveis, conforme apontado em pesquisas anteriores discutidas no item abaixo.

\subsection{Pesquisas e Levantamentos Anteriores sobre as Demandas dos Juizados Especiais}

No dia 05 de agosto de 2004, o Ministro Nelson Jobim, presidente do Supremo Tribunal Federal, reuniu-se com os presidentes do Banco Central, Henrique Meireles, da Agência Nacional de Energia Elétrica (Aneel), José Mario Abdo, e com o superintendente-executivo da Agência Nacional de Telecomunicações (Anatel), Rubens Donati Jorge. Neste encontro, Jobim foi categórico ao afirmar que “é preciso reduzir as causas de litigiosidades”, ainda afirmou que, “além de ampliar a capacidade do Judiciário 
em 'ofertar decisões', também é necessário intervir 'na situação pré-processual, para começar a induzir que essas empresas não se utilizem eventualmente do sistema Judiciário para o não-cumprimento de suas obrigações'.”. ${ }^{20}$

As “empresas” referidas pelo Ministro são as que, no relatório Perfil das Maiores Demandas Judiciais do Tribunal de Justiça do Estado do Rio de Janeiro, aparecem como as mais demandadas nos Juizados Especiais Cíveis cariocas. O resultado deste relatório foi o principal motivo para a realização deste encontro.

Abaixo temos a Tabela 04, do relatório que relaciona as empresas mais demandadas nos Juizados Especiais Cíveis do Estado do Rio de Janeiro:

Tabela 04: Feitos por Ano e Percentual de Participação Geral das Empresas mais Demandadas nos Juizados Especiais Cíveis do Estado do Rio de Janeiro - Número

\begin{tabular}{|c|c|c|c|c|c|}
\hline $\begin{array}{l}\text { Empresas mais } \\
\text { Demandadas }\end{array}$ & 2002 & 2003 & $\begin{array}{c}01 / 01 / 2004 \mathrm{a} \\
30 / 04 / 2004 \\
\end{array}$ & Total Geral & $\begin{array}{c}\% \\
\text { Participação }\end{array}$ \\
\hline Telemar & 52326 & 80741 & 23810 & 156877 & 48,93 \\
\hline $\begin{array}{c}\text { Cerj-Cia. de } \\
\text { Eletricidade do } \\
\text { Rio }\end{array}$ & 10481 & 22082 & 7524 & 40087 & 12,50 \\
\hline $\begin{array}{c}\text { Light - Serviços } \\
\text { de Eletricidade } \\
\text { S/A }\end{array}$ & 6349 & 13803 & 4205 & 24357 & 7,60 \\
\hline Banco Itaú S/A & 4145 & 7784 & 1127 & 13056 & 4,07 \\
\hline $\begin{array}{c}\text { Banco do Brasil } \\
\text { S/A }\end{array}$ & 3338 & 7062 & 2762 & 13162 & 4,11 \\
\hline Banco Bradesco & 3479 & 6634 & 2698 & 12811 & 4,00 \\
\hline Fininvest S/A & 3550 & 5275 & 1702 & 10527 & 3,28 \\
\hline $\begin{array}{c}\text { Banco Banerj } \\
\text { S/A }\end{array}$ & 1596 & 4288 & 3714 & 9598 & 2,99 \\
\hline Embratel & 2384 & 3404 & 1111 & 6899 & 2,15 \\
\hline Credicard & 2115 & 3373 & 937 & 6425 & 2,00 \\
\hline $\begin{array}{l}\text { Telefônica } \\
\text { Celular }\end{array}$ & 1496 & 2945 & 1255 & 5696 & 1,78 \\
\hline $\begin{array}{c}\text { Banco Abn } \\
\text { Amro Bank S/A }\end{array}$ & 1774 & 2600 & 680 & 5054 & 1,58 \\
\hline $\begin{array}{l}\text { C\&A Modas } \\
\text { Cedae - Cia. }\end{array}$ & 1258 & 2993 & 1155 & 5406 & 1,69 \\
\hline $\begin{array}{l}\text { Estadual de } \\
\text { Água e Esgoto }\end{array}$ & 795 & 2275 & 782 & 3852 & 1,20 \\
\hline $\begin{array}{c}\text { Casa Bahia } \\
\text { Comercial Ltda. }\end{array}$ & 873 & 2106 & 993 & 3972 & 1,24 \\
\hline $\begin{array}{c}\text { Cartão Unibanco } \\
\text { Total } \\
\end{array}$ & $\begin{array}{c}942 \\
96901 \\
\end{array}$ & $\begin{array}{c}1651 \\
169016 \\
\end{array}$ & $\begin{array}{c}217 \\
54672 \\
\end{array}$ & $\begin{array}{c}2810 \\
320589 \\
\end{array}$ & $\begin{array}{c}0,88 \\
100,00 \\
\end{array}$ \\
\hline
\end{tabular}

Fonte: Tribunal de Justiça do Estado do Rio de Janeiro, Perfil das Maiores Demandas Judiciais do Tribunal de Justiça do Estado do Rio de Janeiro, 2004.

\footnotetext{
${ }^{20}$ STF, É preciso reduzir as causas de litigiosidades", diz Jobim em reunião com dirigentes do Banco Central,
} Aneel e Anatel, in http://www.stf.gov.br, último acesso em 05/08/2004.. 
No período analisado, as dezesseis empresas mais demandadas registraram um total de 320.589 ações distribuídas nos Juizados, sobre um total de 714.061 feitos desses órgãos. Deste modo, estas empresas respondem por 44,9\% do movimento total dos Juizados Especiais Cíveis cariocas. Considerando a demanda de processos somente contra os principais reclamados prestadores de serviço público, o percentual de participação destes no movimento total nestes anos é de 32,5\%, ou seja, praticamente um terço de todos os processos ingressos nos JEC's cariocas teve como reclamado prestador de serviço público.

Assim, esses órgãos da Justiça do Rio têm uma concentração de demandas em que o pólo passivo é ocupado em quase metade por empresas referentes a compras de baixo valor e, principalmente, empresas prestadoras de serviços públicos, como telefonia fixa, água e esgoto, e distribuição de energia elétrica. As ações propostas são de carteira pulverizada de clientes, envolvendo valores reclamados baixos e na maioria são propostas por pessoas físicas.

As demandas mais comuns nos serviços de água e luz se referem a cortes do fornecimento, por falta de pagamento, ou por suposta violação de equipamentos (medidores), sem aviso prévio, e a cobranças indevidas. Na área de telefonia, clonagem de linhas telefônicas. No setor financeiro, aberturas de contas com documentos falsos, inclusão de nomes nos serviços de proteção ao crédito (SPC e Serasa) e pagamentos feitos por terceiros, com cheques roubados e assinaturas falsificadas.

Melhores especificados, os grupos de atividades das empresas e as porcentagens de participação somadas no total das empresas mais demandadas são:

1. Concessionárias de telefonia fixa e móvel: Telemar, Embratel, Telefônica Celular: 52,86\%.

2. Instituições financeiras: Banco do Brasil, Banco Bradesco, Fininvest, Banco Itaú, Banco Banerj, Banco ABN Amro Bank, Cartão Unibanco, Cartão Credicard e Bradesco Seguros: 22,91\%.

3. Concessionárias de luz, água e esgoto: Cerj, Light e Cedae: $21,30 \%$.

4. Fornecedores de bens e serviços sujeitos às normas de defesa do consumidor: C\&A Modas e Casas Bahia: 2,93\%.

Diante desses dados, podemos concluir que 97,07\% das demandas das dezesseis maiores empresas são sobre a prestação de serviços públicos objeto de regulação por agências (ANATEL, ANEEL, ANA e Banco Central), alcançando 311.211 feitos de 2002 
ao primeiro quadrimestre de 2004 , e participando com $46,6 \%$ do total das demandas dos Juizados Especiais. Observa-se que a Telemar, concessionária de serviços telefônicos, é, somente ela, responsável por 48,93\% das demandas das maiores empresas dos Juizados do Rio.

Outros levantamentos para o Estado do Rio de Janeiro também apontam para o alto número de casos relacionados com o consumo de bens e serviços. Como é o caso da pesquisa de D’Araujo (1996), que chega a encontrar em um Juizado 45\% de ações dessa natureza.

No mesmo Estado, Vianna et alli (1998) aponta que, desde a implantação desses Juizados na sua capital até Abril de 1998, as categorias responsáveis por 76\% do total de feitos compreendem “Outros feitos com valor até 40 salários mínimos”, com 50,7\% (categoria que inclui ações indenizatórias, como as de dano moral), seguidas das ações relativas ao direito do consumidor, com $36,5 \%$, e cobranças de títulos extrajudiciais, com 15,6\%. Segundo os autores:

“O aumento da litigância, decorrente da criação dos Juizados Especiais Cíveis, deve ser compreendido à base de dois movimentos principais: o dos consumidores em face das empresas, em razão do mais fácil acesso à Justiça e de novos meios, colocados à sua disposição, para se defenderem; e o de indivíduos contra outros indivíduos, quer em questões de clássica intervenção do Judiciário, como nas cobranças extrajudiciais, que em questões antes solucionadas no interior da vida comunitária...”.(p.198)

Porém, de 1994 a 1998 os dados levantados pelos autores apontam para um decréscimo nos casos de defesa do consumidor, de 33,4\%, com o crescimento das causas de relações interpessoais.

Carneiro (2003), em sua pesquisa também na cidade do Rio de Janeiro, apresenta dados diversos com relação à participação das causas de consumo nos Juizados desta capital. Afirma o autor que:

“Apesar de pequenas variações percentuais, pode-se afirmar com precisão que em todos os Juizados pesquisados, pelo menos $50 \%$ das 
causas têm por base uma relação de consumo, não só aquelas consideradas típicas, como também aquelas de indenização por danos morais e materiais que apresentam por base uma relação de consumo". (p.139)

E, com relação à natureza dos reclamados encontrados em seu levantamento, em um dos Juizados pesquisados, que, nos dizeres do autor, pode ser expandido para pesquisas em outros JEC's, a participação percentual por tipos é de 33,7\% de pessoas físicas, 13,5\% relativos à Telerj (Telemar), 5,6\% viações, 4,5\% bancos, 3,4\% planos de saúde, 2,3\% Light, estabelecimentos de ensino e centrais de telefones. Para os Juizados que se localizam no centro da cidade, os percentuais de participação são de 18,5\% para a Telerj (Telemar), 11\% bancos, 8,4\% central de telefones, e 3,2\% Credicard Administradora de Cartões de Crédito S/A.

As ações promovidas contra estes tipos de reclamados têm objeto comum. Contra a Telemar, os objetos das ações são pedido de instalação de aparelho telefônico em virtude de expiração do prazo previsto contratualmente para tanto, ou perdas e danos, decorrentes da falta de uso e de fruição do aparelho. Contra os bancos, casos de cobrança indevida de juros e taxas, de indenização por danos morais, porque o banco não retirou o nome do correntista do SPC, mesmo com o pagamento de débito efetuado. Contra as empresas de prestação de serviços de saúde, as causas mais comuns versam sobre a extensão da cobertura dos planos, de aplicação de índices indevidos no aumento das mensalidades, sendo que este último fato também é comum de ocorrer nas ações contra estabelecimentos de ensino. Contra a Ligth, o autor cita como motivo de ingresso de ações danos diversos decorrentes da falta de energia.

No estudo de Sanches Filho (2001) sobre acesso à justiça no Estado da Bahia, o autor indica tendências de aumento do movimento processual dos Juizados entre os anos de 1998 e 1999, com aumento nos Juizados especializados em causas de direito de consumo de 94\%, nos Juizados de causas de trânsito de 50\%, e nos Juizados de causas cíveis comuns de $2 \%$, e afirma:

"Com base nisso, é possível afirmar que ou houve um crescimento dos problemas gerados pelas relações de consumo, ou os cidadãos tiveram um conhecimento maior das atribuições dos Juizados, apesar 
da 'concorrência com outras instituições, como o Procon, por exemplo"(p. 90).

Para o Estado de São Paulo, no final da década de 80, Maria Cecília MacDowell, ao analisar o funcionamento dos primeiros juizados informais de conciliação na capital, já indicava a predominância de relações de venda e compra nos casos entrados (apud Cunha 2004, p. 91).

Faisting (1995) aponta em sua pesquisa nos Juizados de Pequenas Causas da cidade de São Carlos nos anos de 1993 a 1995, que, com relação à natureza dos litígios, 97,3\% referem-se a condenação em dinheiro. Tais causas dizem respeito a acidentes de trânsito, prestação de serviços, problemas entre inquilinos e proprietários, cobranças, reclamações de mercadorias entregues com defeito ou fora do prazo. Para o autor, tal fato revela que as pessoas buscam o juizado na maioria dos casos para o ressarcimento de seus prejuízos em dinheiro, sendo inexpressivos casos cuja natureza não envolva recursos financeiros.

A demanda dos Juizados especificamente contra prestadores de serviços públicos é apontada na pesquisa de Desasso (2001), um dos autores que lida com as classificações dos reclamados nos processos em seu levantamento sobre o Juizado Especial da cidade paulista de Carapicuíba no ano de 1999. Este autor afirma que:

“As pessoas jurídicas representam 1/3 dos réus arrolados em processos no ano de 1999, com predominância de determinados ramos de atividades: administradoras de telefones; empresas concessionárias de serviços públicos - água, esgoto, telefonia e energia; lojas de móveis e eletrodomésticos; e empresas de transportes coletivos.” (p. 75) (grifo nosso)

Na pesquisa realizada em 2003 pelo Centro Brasileiro de Estudos e Pesquisas Judiciais, que entrevistou 721 indivíduos que procuraram os Juizados Especiais Cíveis no Estado de São Paulo, os resultados apontam para uma baixa participação dos serviços públicos como demanda dos JEC's. Abaixo apontamos a tabela 05, de respostas ao quesito do motivo de procura dos Juizados Especiais Cíveis: 


\begin{tabular}{|c|c|c|c|c|c|c|}
\hline \multirow[t]{2}{*}{ Problema com: } & \multicolumn{2}{|c|}{ Capital } & \multicolumn{2}{|c|}{ Interior/Litoral } & \multicolumn{2}{|c|}{ Total } \\
\hline & Não & $\%$ & $\mathrm{~N}$ & $\%$ & $\mathrm{~N}$ & $\%$ \\
\hline Cobrança & 148 & 35,8 & 186 & 61,2 & 334 & 46,6 \\
\hline Outro & 94 & 22,8 & 23 & 7,6 & 117 & 16,3 \\
\hline $\begin{array}{c}\text { Acidente de } \\
\text { Trânsito }\end{array}$ & 73 & 17,7 & 30 & 9,9 & 103 & 14,4 \\
\hline Consumo & 54 & 13,1 & 19 & 6,3 & 73 & 10,2 \\
\hline Locação & 31 & 7,5 & 31 & 10,2 & 62 & 8,6 \\
\hline Serviço Público & 23 & 5,6 & 15 & 4,9 & 38 & 5,3 \\
\hline Plano de Saúde & 15 & 3,6 & 5 & 1,6 & 20 & 2,8 \\
\hline Total & 413 & 100,0 & 304 & 100,0 & 717 & 100,0 \\
\hline
\end{tabular}

Fonte: CEBEPEJ, Pesquisa Juizados Especiais Cíveis, 2003.

Observamos que as questões sobre serviços públicos ocorrem em apenas 38 respostas, 5,3\% dos motivos arrolados pelos autores para irem ao Juizado Especial, e as demandas de consumo respondem por $10,2 \%$. Por outro lado, as demandas de cobrança alcançam quase metade dos feitos indicados pelos entrevistados: 46,6\%, seguidas das causas de acidente de trânsito, com 14,4\%.

A pesquisa de Cunha (2004), que abrange os anos de 1992 a 2002, no Juizado Especial Cível Central de São Paulo, aponta para a predominância de causas com pessoas jurídicas no pólo passivo da demanda: 58,1\% dos reclamados têm essa natureza. Para a autora, tal fato relaciona-se à natureza das demandas encontradas, que apresenta $49 \%$ de conflitos relativos a relações de consumo. Durante todo o período analisado, este tipo de ação é predominante em todos os anos, e, a partir de 1998 apresentou crescimento em sua participação.

O levantamento mais recente sobre os Juizados Especiais foi realizado pelo Centro Brasileiro de Estudos e Pesquisas Judiciais - CEBEPEJ, em parceria com o Ministério da Justiça. Foram pesquisados JEC's em nove diferentes capitais de Estados brasileiros, consultando amostra elaborada dos feitos distribuídos no ano de 2002. Os dados desta pesquisa indicam que o principal tipo de reclamação nos Juizados são as relativas às relações de consumo, 37,2\% dos tipos de feitos encontrados apresentaram esta natureza. A Tabela 06 indica o percentual das reclamações de relações de consumo por capital pesquisada. 
Tabela 06: Reclamações sobre Relação de Consumo nos Juizados Especiais por Capital - Percentual

\begin{tabular}{cc}
\hline \hline Capital & Percentual \\
\hline Rio de Janeiro & 79,0 \\
Belo Horizonte & 55,3 \\
São Paulo & 50,8 \\
Belém & 33,8 \\
Salvador & 33,4 \\
Porto Alegre & 32,1 \\
Goiânia & 31,3 \\
Macapá & 10,2 \\
Fortaleza & 7,7 \\
Total & 37,5 \\
\hline \hline Fonte: Ministério da Justiça/CEBEPEJ 2006
\end{tabular}

Esta tabela demonstra que, considerados diferentes Estados brasileiros há uma presença maciça de ações relativas à relações de consumo nos Juizados Especiais. O Rio de Janeiro foi a capital que apresentou, proporcionalmente, o maior valor desta natureza de feito: 79,0 \%. Belo Horizonte e São Paulo são as duas outras capitais cujos feitos relativos às relações de consumo ocorrem em mais da metade da amostra, participando este tipo de ação com 55,3\% e 50,8\% respectivamente.

Aproximadamente um terço da amostra das ações entradas em 2002 nas capitais Belém, Salvador, Porto Alegre e Goiânia são de feitos sobre consumo. Macapá apresenta 10,2\% deste tipo de feito, e Fortaleza o menor valor: 7,7\%.

A pesquisa indica que Fortaleza apresentou esta baixa participação de feitos sobre consumo devido à grande presença de demandas sobre acidentes de trânsito, que representam 60,4\% dos processos desta capital.

Analisando sobre quais relações de consumo esses feitos diziam respeito, este levantamento observou que a principal reclamação é sobre os serviços de telecomunicações. O percentual médio nacional para essa natureza de litígio é de 22,8\%. A tabela 07 discrimina o percentual deste tipo de reclamação por capital pesquisada. 
Tabela 07: Reclamação sobre Serviço de Telecomunicação por Capital - Percentual

\begin{tabular}{cc}
\hline \hline Capital & Percentual de reclamação sobre serviço de telecomunicação \\
\hline Fortaleza & 44,2 \\
Macapá & 41,9 \\
Rio de Janeiro & 33,6 \\
Salvador & 32,4 \\
Belém & 27,5 \\
Porto Alegre & 25,1 \\
Belo Horizonte & 10,0 \\
São Paulo & 9,2 \\
Goiânia & 9,1 \\
Média Total & 22,8 \\
\hline \hline
\end{tabular}

Fonte: Ministério da Justiça/CEBEPEJ 2006

Observa-se que Fortaleza e Macapá, apesar de serem as capitais que apresentam a menor participação percentual de conflitos relativos à consumo, têm neste tipo de demanda uma expressiva presença de reclamações sobre serviço de telecomunicações: 44,2\%. Porém não podemos afirmar que há uma relação entre a menor presença de feitos sobre consumo e a maior participação de reclamações sobre serviços de telecomunicações, pois capitais como Rio de Janeiro, Belém, Porto Alegre e Salvador, que têm expressiva presença de demandas relativas às relações de consumo, apresentam percentuais de reclamação sobre serviços de telecomunicações que vão de $25 \%$ a cerca de $30 \%$.

Conclui-se que grande parte das pesquisas e levantamentos acerca do funcionamento dos Juizados Especiais Cíveis apontam as demandas de consumo como as mais freqüentes nos processos dos Juizados, bem como a existência de um expressivo percentual de empresas no pólo passivo das demandas. A questão a ser esclarecida está no fato de que as reclamações sobre serviços públicos são em grande parte incluídas como problemas de relação de consumo. Para a maioria das pesquisas consultadas não é levada em conta a natureza do reclamado para aferir o quanto desta relação de consumo decorreu ou não da prestação de um serviço público, como telefonia, água e esgoto, ou energia elétrica. Diante desse fato, o presente estudo pretende debruçar-se sobre esta questão, analisando os dados de três Juizados da cidade de São Paulo para aferir se este novo instrumento de efetivação do acesso à justiça tornou-se um "balcão de reclamação" sobre os serviços públicos. 


\section{Capítulo 03 - Pesquisa de Campo: Feitos Distribuídos em Três Juizados}

Especiais da Comarca de São Paulo

\subsection{Hipóteses e desenvolvimento da pesquisa}

O objetivo do presente capítulo é analisar a demanda de três Juizados Especiais Cíveis da cidade de São Paulo, tendo em vista a natureza das ações e os tipos de seus reclamantes e reclamados. Pretende-se, por meio dos dados levantados, aferir a participação nos Juizados Especiais Cíveis paulistanos das empresas prestadoras de serviço público, com o objetivo de confirmar ou desconfirmar a hipótese geral de que os Juizados Especiais transformaram-se em "balcão de reclamação” sobre serviços públicos.

Com base nos dados e pesquisas anteriormente apresentados, pode-se fixar as seguintes hipóteses:

1. Os Juizados Especiais Cíveis têm como principal tipo de reclamante as pessoas físicas;

2. Os Juizados Especiais Cíveis têm como principal tipo de reclamado as pessoas jurídicas;

3. Os Juizados Especiais Cíveis têm expressiva presença de empresas concessionárias de serviços públicos de telefonia fixa, água e esgoto, e distribuição de energia elétrica como reclamados de seus processos.

Estas hipóteses serão testadas por meio do levantamento de três

variáveis categóricas:

Tabela 08: Variáveis Categóricas e Objetivo de sua Observação

Variável

Tipo de Autor

Tipo de Reclamado

Natureza da Demanda

\section{Objetivo}

Verificar o atendimento de demandas de cidadãos (Hipótese 01)

Verificar a presença de pessoas jurídicas e de empresas prestadoras de serviços públicos

(Hipótese 02)

Verificar a presença de demandas de consumo e de prestação de serviço público

(Hipóteses 03) 
Estas variáveis foram obtidas através do processo de amostragem sistemática dos processos, com base nos Livros de Registros de Feitos dos anos de 2000, 2001, 2002, 2003, 2004 e 2005 (até a data de 11/11/2005, dada a alteração, a partir desta data, do sistema de registro de feitos, o que tornou indisponível dados posteriores) de três Juizados da Comarca de São Paulo:

1. Juizado Especial Cível do Fórum Regional VII - Pinheiros

1. Juizado Especial Cível do Centro de Integração da Cidadania da Zona Oeste - CIC Oeste

2. Juizado Especial Cível do Centro de Integração da Cidadania da Zona Leste - CIC Leste (este Juizado foi instalado em maio de 2003, e, por esta razão foram pesquisados apenas os últimos 3 anos da série).

A amostra retirada foi de aproximadamente 5\% para o Juizado de Pinheiros, e de aproximadamente 10\% para os Juizados dos CIC's, dada a quantidade menor de ações distribuídas por ano nestes dois últimos JEC's. Ao todo foram levantadas informações de tipo de reclamante, tipo de reclamado e tipo de ação de 2.235 feitos, distribuídos por ano e Juizado conforme indicado na tabela 09 abaixo:

Tabela 09: Montagem da Amostra por Ano e por Juizado Pesquisado

\begin{tabular}{c|cc|cc|cc}
$\begin{array}{c}\text { Juizado } \\
\text { Pesquisado }\end{array}$ & \multicolumn{2}{c}{ Pinheiros } & \multicolumn{2}{c}{ CIC Oeste } & \multicolumn{2}{c}{ CIC Leste } \\
\hline Ano & $\begin{array}{c}\text { Feitos } \\
\text { Distribuídos }\end{array}$ & $\begin{array}{c}\text { Tamanho } \\
\text { da Amostra }\end{array}$ & $\begin{array}{c}\text { Feitos } \\
\text { Distribuídos }\end{array}$ & $\begin{array}{c}\text { Tamanho } \\
\text { da Amostra }\end{array}$ & $\begin{array}{c}\text { Feitos } \\
\text { Distribuídos }\end{array}$ & Tamanho \\
& 2.765 & 139 & 911 & 94 & & \\
2000 & 2.818 & 141 & 807 & 83 & & \\
2001 & 3.834 & 193 & 814 & 84 & & \\
2003 & 4.107 & 209 & 751 & 79 & 1.245 & 123 \\
2004 & 3.700 & 187 & 744 & 78 & 1.452 & 146 \\
2005 & 3.563 & 178 & 991 & 99 & 4.945 & 402 \\
Total & 20.787 & 1.047 & 5.018 & 517 & 6.403 & 671 \\
\hline
\end{tabular}

As classificações para o tipo de reclamante foram Pessoa Física, Micro Empresa e Condomínio ${ }^{21}$. A classificação do tipo de ação levou em conta as descrições encontradas nos livros de registro. A classificação do tipo do reclamado foi, em um primeiro momento, de Pessoa Física, Micro Empresa e Pessoa Jurídica, e dentre as Pessoas Jurídicas encontradas no pólo passivo da demanda, foi utilizada a Classificação Nacional de Atividades Econômicas do IBGE, destacando-se os casos encontrados de concessionárias prestadoras de serviço público. 
A escolha desses Juizados Especiais Cíveis levou em conta as diferenças sócio-econômicas das regiões atendidas, bem como a diversidade dos projetos e convênios realizados pelo Tribunal de Justiça de São Paulo para implantar essas unidades. O objetivo é representar as diferentes experiências de promoção do acesso à justiça. O item abaixo analisa estas diferenças.

\subsection{Os Juizados Pesquisados}

Dos três Juizados pesquisados, apenas um, o de Pinheiros, localiza-se em um Fórum, estrutura clássica do Poder Judiciário. Os demais fazem parte do projeto Centro de Integração da Cidadania do Governo do Estado de São Paulo, capitaneado pela Secretaria da Justiça e Defesa da Cidadania.

Conforme Araújo (2001, p. 206), o CIC teria por objetivo principal encurtar a distância física dos órgãos estatais para a população residente na periferia de São Paulo. Seu projeto parte do diagnóstico de "ausência” do Estado em áreas da periferia, bem como da necessidade de “proximidade física” (Haddad et alli, 2003, pp.37-39). O projeto procura superar os entraves burocráticos da prestação desses serviços, concentrando em um só espaço físico o atendimento de diversos órgãos públicos.

Com origem no Decreto Estadual 46.000, de 15 de agosto de 2001, que criou e organizou a Coordenadoria de Integração da Cidadania no âmbito da Secretaria da Justiça do Estado de São Paulo, sua concepção revela a articulação entre os Poderes Executivo, Judiciário, bem como do Ministério Público e da Sociedade Civil.. Essa articulação ocorre em torno de quatro núcleos ${ }^{22}$ :

\section{NÚCLEO DE SEGURANÇA PÚBLICA}

A) Delegacia da Policia Civil: Delegacia especializada, que atua na mediação dos conflitos.

B) I.I.R.G.D: Instituto de identificação que providencia emissão de segundas vias de RG's.

C) Policia Militar: Bases Comunitárias da Polícia Militar.

${ }^{21}$ A presença de “Condomínio” como autor em Juizados Especiais será analisada no item 4.3 abaixo. 


\section{NÚCLEO DE ACESSO À JUSTIÇA}

A) Tribunal de Justiça: através dos Juizados instalados nos CIC's, com o objetivo de proporcionar a democratização da justiça, integrando tal serviço público à comunidade.

B) Promotoria de Justiça: atende as demandas da comunidade concernentes à orientação jurídica, emissão de solicitação de $2^{\mathrm{a}}$ via de certidões de nascimento, casamento e óbito, solicitação de registro tardio, faz reconhecimento de paternidade, acordo de pensão alimentícia, guarda e visita, alvarás, entre outras atividades.

C) Procuradoria de Assistência Judiciária: orientação jurídica, acompanhamento de processos e execução.

D) PROCON: atendimento aos consumidores, orientação sobre o Direito do Consumidor, através do Código de Defesa do Consumidor e, quando necessário, aciona fornecedores.

E) FEBEM: atendimento da medida socio-educativa de Liberdade Assistida, prevista no Estatuto da Criança e do Adolescente. Em tal medida, o adolescente e sua família são acompanhados por assistentes sociais e psicólogos durante um período determinado.

\section{NÚCLEO DE ASSISTÊNCIA E DESENVOLVIMENTO SOCIAL}

A) CDHU: orientar e assistir aos mutuários nos assuntos referentes à renegociação e atualização de dívidas, revisão de prestação, além de cálculo e esclarecimento sobre prestações em atraso.

B) PAT e Emissão de Carteira Profissional: serviços prestados pela Secretaria do Emprego e Relações de Trabalho, como o Balcão de Empregos, que abre novas perspectivas na recolocação profissional. Outro fator que traz benefícios à população usuária do balcão de emprego é a orientação com relação à postura profissional, documentação e vestuário adequado para que os mesmos obtenham sucesso na busca de uma colocação no mercado de trabalho.

C) Fundo Social de Solidariedade: participação por meio de diversas parcerias com Associações e ONG's com implementação de cursos e programas que beneficiem a população local nas propostas de geração de renda.

D) Assistência Social: serviço social nos postos CIC, que realiza atendimentos e orientações, fazendo encaminhamentos para diversos setores do CIC e/ou órgãos externos.

\footnotetext{
${ }^{22}$ Informações obtidas no endereço eletrônico www.justica.sp.gov.br/Cic/projeto tecnico_cic.doc, último acesso em 19/07/2005.
} 
E) Acessa São Paulo: infocentro, que oferece à comunidade o acesso à informática, e inúmeras atividades, através do acesso à Internet para cursos digitais.

F) Saúde: serviços relacionados à prevenção de doenças como exames mais simples, palestras e orientações.

\section{NÚCLEO GERENCIAL - COORDENADORIA DE INTEGRAÇÃO DA CIDADANIA}

A) Todos os serviços referentes à administração e gestão técnica do programa.

A primeira experiência de implantação do CIC ocorreu em 1996, na Zona Leste, no distrito do Itaim Paulista. No que se refere ao núcleo de acesso à justiça, instalou-se em um primeiro momento o Juizado Informal de Conciliação. Entretanto, conforme Haddad et alli (2003, pp. 95,105 e 106), esse tipo de Juizado apresenta uma competência muito restrita, não havendo possibilidade de execução de acordos descumpridos. As autoras mencionam o depoimento do diretor do cartório desse Juizado Informal de Conciliação, informando que, à época, o Conselho Superior da Magistratura aprovou a criação de um Juizado Especial Cível no CIC Leste, mas, em razão da falta de verba para equipamento e pessoal, a instalação do mesmo foi vetada pela Presidência do Tribunal de Justiça Em 2003 finalmente foi instalado o Juizado Especial no CIC Leste.

O CIC - Oeste, ao contrário do CIC Leste, desde a sua instalação no final do ano de 1998, contou em sua estrutura com Juizado Especial Cível representando a participação do Tribunal de Justiça no projeto.

O Fórum de Pinheiros foi um dos primeiros na cidade de São Paulo a contar com a estrutura de Juizado de Pequenas Causas, que depois foi transformada, com o advento da lei 9.099/95, em Juizado Especial Cível.

Para aferirmos as diferenças das regiões atendidas pelos Juizados pesquisados fixamos os distritos da Cidade de São Paulo sob a competência de cada um, conforme indicado na tabela 10 abaixo: 
Tabela 10: Abrangência Geográfica dos Juizados Especiais Cíveis por Distrito da Cidade de São Paulo

\begin{tabular}{ccc}
\hline Pinheiros & CIC - Oeste & CIC - Leste \\
\hline \hline Morumbi & Lapa & Ponte Rasa \\
Pinheiros & Barra Funda & Ermelino Matarazzo \\
Alto de Pinheiros & Vila Leopoldina & São Miguel \\
Butantã & São Domingos & Itaim Paulista \\
Vl. Sônia & Pirituba & Vl. Curuça \\
Jaguaré & Anhangüera & Jardim Helena \\
Rio Pequeno & Freguesia do Ó & Vl. Jacuí \\
Raposo Tavares & Jaguará & Lajeado \\
& Perus & \\
& Jaraguá & \\
\hline \hline
\end{tabular}

Fonte: Cartórios dos Juizados Especiais de Pinheiros, CIC Oeste e CIC Leste

Com base nos dados populacionais do Município de São Paulo no ano de 2004, a população localizada nos distritos atendidos por esses três Juizados representa 26,62\% da população total da Capital. Abaixo, a tabela 11 indica o número e percentual de habitantes por região de abrangência geográfica:

Tabela 11: Habitantes das Regiões de Abrangência Geográfica dos Juizados Especiais Cíveis no Ano de 2004 - Número e Percentual

\begin{tabular}{cccccc}
\hline \hline Juizado & Pinheiros & CIC - Oeste & CIC - Leste & Município de São Paulo \\
& \multicolumn{5}{c}{ Total } \\
\hline Número & 520.669 & 1.067 .748 & 1.151 .984 & 2.740 .401 & 10.679 .760 \\
Percentual & 4,88 & 10,00 & 10,79 & 25,67 & 100,00 \\
relativo ao & \multicolumn{5}{c}{} \\
Município & \multicolumn{7}{l}{} \\
\hline \hline
\end{tabular}

O JEC do Fórum de Pinheiros tem a competência territorial para atendimento de uma população que representa proporcionalmente menos da metade dos outros dois Juizados separadamente. Porém, devemos observar que, no caso dos JEC's do CIC - Leste e do CIC - Oeste, existem, respectivamente, o Fórum Regional V - Lapa e o Fórum Regional X - São Miguel, que têm a competência para atender a mesma região, mesmo que não localizados nos extremos da periferia como os CIC's.

A população da abrangência geográfica dos Juizados pesquisados é dividida por grupos de idades na tabela 12. 
Tabela 12: Habitantes por Faixa Etária e por Região de Abrangência Geográfica dos Juizados Especiais no Ano de 2004 - Número e Percentual

\begin{tabular}{c|cc|cc|ccc|cc}
\hline Faixa Etária & \multicolumn{2}{c}{0 a 17 anos } & \multicolumn{2}{c}{18 a 59 anos } & \multicolumn{2}{c}{ 60 Anos e Mais } & \multicolumn{2}{c}{ Total } \\
\hline \hline Juizado & $\mathrm{N}$ & $\%$ & $\mathrm{~N}$ & $\%$ & $\mathrm{~N}$ & $\%$ & $\mathrm{~N}$ & $\%$ \\
Pinheiros & 132140 & 25,38 & 325810 & 62,58 & 62719 & 12,05 & 520669 & 100,00 \\
CIC Oeste & 325777 & 30,51 & 643809 & 60,30 & 98162 & 9,19 & 1067748 & 100,00 \\
CIC Leste & 399818 & 34,71 & 675242 & 58,62 & 76924 & 6,68 & 1151984 & 100,00 \\
Município de São Paulo & 3126725 & 29,28 & 6489907 & 60,77 & 1063128 & 9,95 & 10679760 & 100,00 \\
\hline \hline
\end{tabular}

Fonte: SEADE - População Total, por Grupos de Idade, segundo Subprefeituras e Distritos do Município de São Paulo - 2004.

Para a faixa etária de 0 a 17 anos, a região atendida pelo Fórum de Pinheiros apresenta 25,4\% de sua população, o menor valor percentual relativo às regiões do CIC Oeste e CIC Leste, que apresentam 30,5\% e 34,7\%, respectivamente. A faixa etária de mais de 60 anos tem na região atendida pelo JEC de Pinheiros o maior valor percentual, 12,1\%; os Juizados do CIC Oeste e CIC Leste apresentam 9,2\% e 6,7\% respectivamente. Apesar da diferença apresentada entre os percentuais, o cálculo do qui-quadrado para observar a significância estatística entre os valores apresentados tem como resultado 3,45, indicando que não há uma diferença significante entre os valores apresentados de população por faixa etária.

Abaixo apresentamos a Tabela 13 e o Gráfico 01, referentes à média do valor percentual de domicílios por faixa de renda per capita e por região de competência dos Juizados pesquisados:

Tabela 13: Domicílios por Faixa de Renda Per Capita por Região de Competência dos Juizados Especiais - Percentual

\begin{tabular}{cccccc}
\hline Faixa Salarial & $\begin{array}{c}\text { Menos de 1/2 } \\
\text { SM }\end{array}$ & $\begin{array}{c}\text { De 1/2 a } \\
\text { Menos de 1 }\end{array}$ & De 1 a Menos De 3 a Menos & De 10 SM e \\
& SM & de SM & de 10 SM & Mais \\
\hline \hline Pinheiros & 4,98 & 6,87 & 24,26 & 33,11 & 30,78 \\
CIC Oeste & 7,65 & 11,89 & 39,22 & 30,71 & 10,53 \\
CIC Leste & 14,25 & 19,61 & 46,21 & 18,36 & 1,58 \\
Média Geral & 8,96 & 12,79 & 36,56 & 27,39 & 14,30 \\
\hline \hline
\end{tabular}

Fonte: SEADE - Percentual de Domićlíos por Faixa de Renda per capita, segundo Subprefeituras e Distritos do Município de São Paulo 


\section{Gráfico 01}

Percentual de Domicílios por Faixa de Renda Salarial e por Juizado

Pesquisado

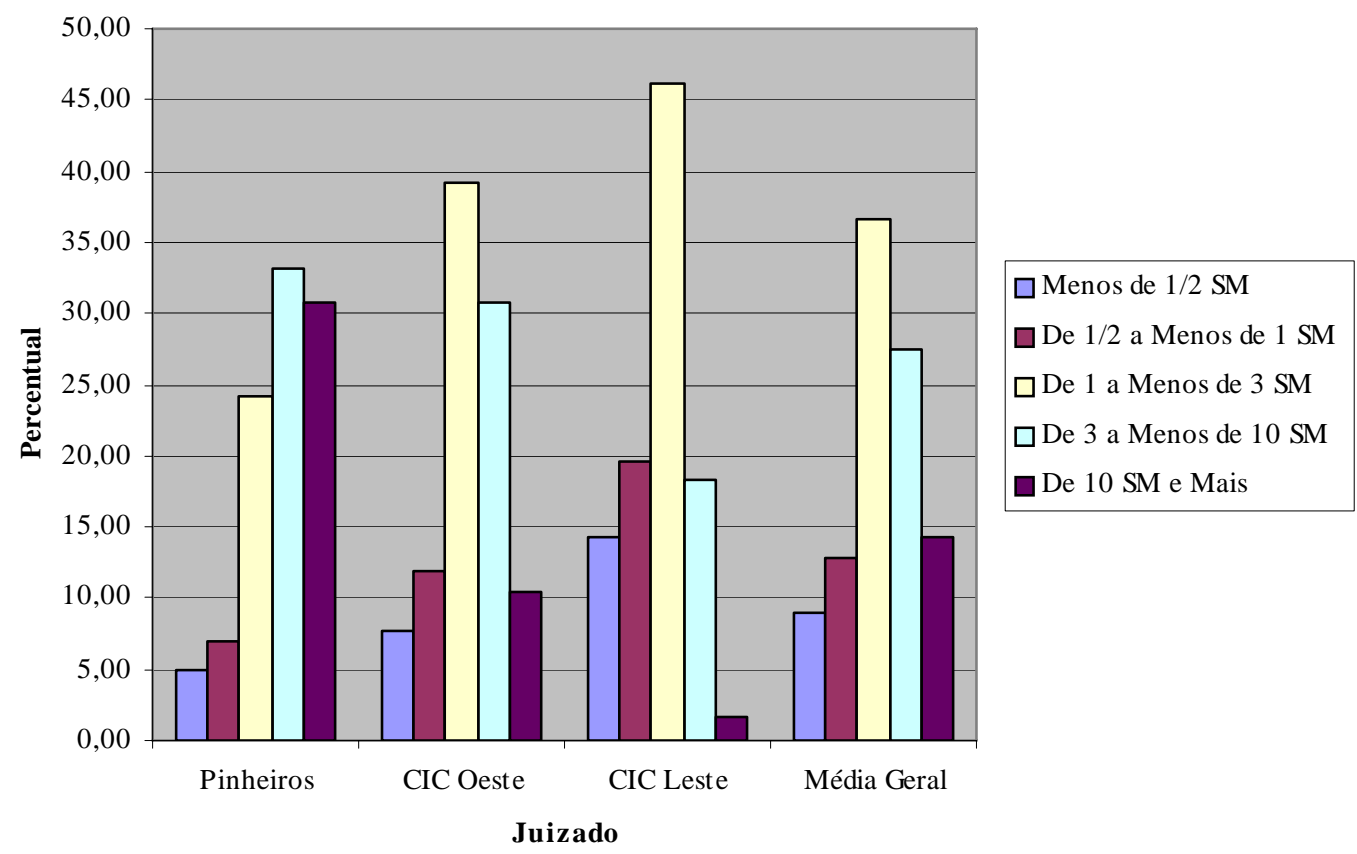

Fonte: SEADE - Percentual de Domicílios por Faixa de Renda per capita, segundo Subprefeituras e Distritos do Município de São Paulo

Há uma grande presença de domicílios com renda per capita com valores de menos de $1 / 2$ até 3 salários mínimos na região geográfica do CIC Leste, com 80,07\% de seus domicílios nessa faixa. A região de competência do Fórum de Pinheiros apresenta os maiores valores médios percentuais nas faixas salariais de 3 a mais de 10 salários mínimos, com 63,79\% dos domicílios nessa categoria. A região atendida pelo CIC Oeste apresenta uma grande participação percentual dos domicílios nas faixas de 1 a menos de 10 salários mínimos, que engloba 69,73\% dos domicílios de sua região.

O cálculo do qui-quadrado para aferir a relevância da diferença apresentada resultou em 54,28, maior que o valor tabelado para grau de liberdade 8 e significância de 0,01. Neste caso podemos afirmar, com 99\% de confiança, que há uma diferença estatisticamente relevante entre as três regiões atendidas, com a região atendida pelo Fórum de Pinheiros apresentando-se como a mais rica, em termos de percentual de domicílios por renda per capita, e a região do CIC Leste como a mais pobre, nos mesmos termos, localizando-se a região atendida pelo CIC Oeste na posição média de ambas. 
Para fixarmos as diferenças econômicas e sociais dessas duas regiões temos o Índice de Desenvolvimento Humano (IDH) como um bom indicador. Criado no início da década de 90, o IDH foi elaborado no contexto do PNUD (Programa das Nações Unidas para o Desenvolvimento), e resulta da combinação de três dimensões:

1. longevidade (medida pela esperança de vida ao nascer)

2. educação (medida pela combinação da taxa de alfabetização de adultos, com peso 2/3, e da taxa de matrícula nos três níveis de ensino, com peso 1/3)

3. renda (medida pelo PIB per capita, expresso em dólares PPC, ou "paridade do poder de compra”). ${ }^{23}$

A tabela 14 e o gráfico 02 abaixo indicam um ranking dos distritos atendidos por esses três Juizados conforme o valor de IDH apresentado em 1990: 
Tabela 14: Índice de Desenvolvimento Humano por Distrito da Cidade de São Paulo sob a Competência Territorial dos JEC's Pinheiros, CIC - Oeste e CIC-Leste - Ano 2000

\begin{tabular}{ccc}
\hline Juizado & Distrito & IDH \\
\hline Pinheiros & Morumbi & 0,860 \\
Pinheiros & Pinheiros & 0,833 \\
Pinheiros & Alto de Pinheiros & 0,801 \\
Pinheiros & Butantã & 0,716 \\
CIC - Oeste & Lapa & 0,661 \\
Pinheiros & Vl. Sônia & 0,646 \\
CIC - Oeste & Barra Funda & 0,575 \\
Pinheiros & Jaguaré & 0,573 \\
Pinheiros & Rio Pequeno & 0,561 \\
CIC - Oeste & Vila Leopoldina & 0,542 \\
CIC - Oeste & São Domingos & 0,536 \\
CIC - Oeste & Pirituba & 0,529 \\
CIC - Oeste & Anhangüera & 0,528 \\
CIC - Oeste & Freguesia do Ó & 0,525 \\
CIC - Oeste & Jaguará & 0,523 \\
Pinheiros & Raposo Tavares & 0,508 \\
CIC - Leste & Ponte Rasa & 0,490 \\
CIC - Leste & Ermelino Matarazzo & 0,464 \\
CIC - Leste & São Miguel & 0,451 \\
CIC - Oeste & Perus & 0,442 \\
CIC - Oeste & Jaraguá & 0,440 \\
CIC - Leste & Itaim Paulista & 0,434 \\
CIC - Oeste & Brasilândia & 0,432 \\
CIC - Leste & Vl. Curuça & 0,431 \\
CIC - Leste & Jardim Helena & 0,409 \\
CIC - Leste & Vl. Jacuí & 0,406 \\
CIC - Leste & Lajeado & 0,397 \\
\hline \hline
\end{tabular}

Fonte: Secretaria do Desenvolvimento, Trabalho e Solidariedade - PMSP, 2000.

\footnotetext{
${ }^{23}$ As indicações sobre o conceito de IDH foram as mesmas utilizadas no texto de Sadek et alli (2001, p.17). Interessante notar que, neste mesmo texto, há a indicação de uma correlação positiva entre a melhora desse índice e o aumento do número de processos entrados na Justiça.
} 


\section{Gráfico 02}

Posição Relativa do IDH dos Distritos Atendidos pelos JEC's de Pinheiros (1), CIC-Oeste (2) e CIC-Leste (3)

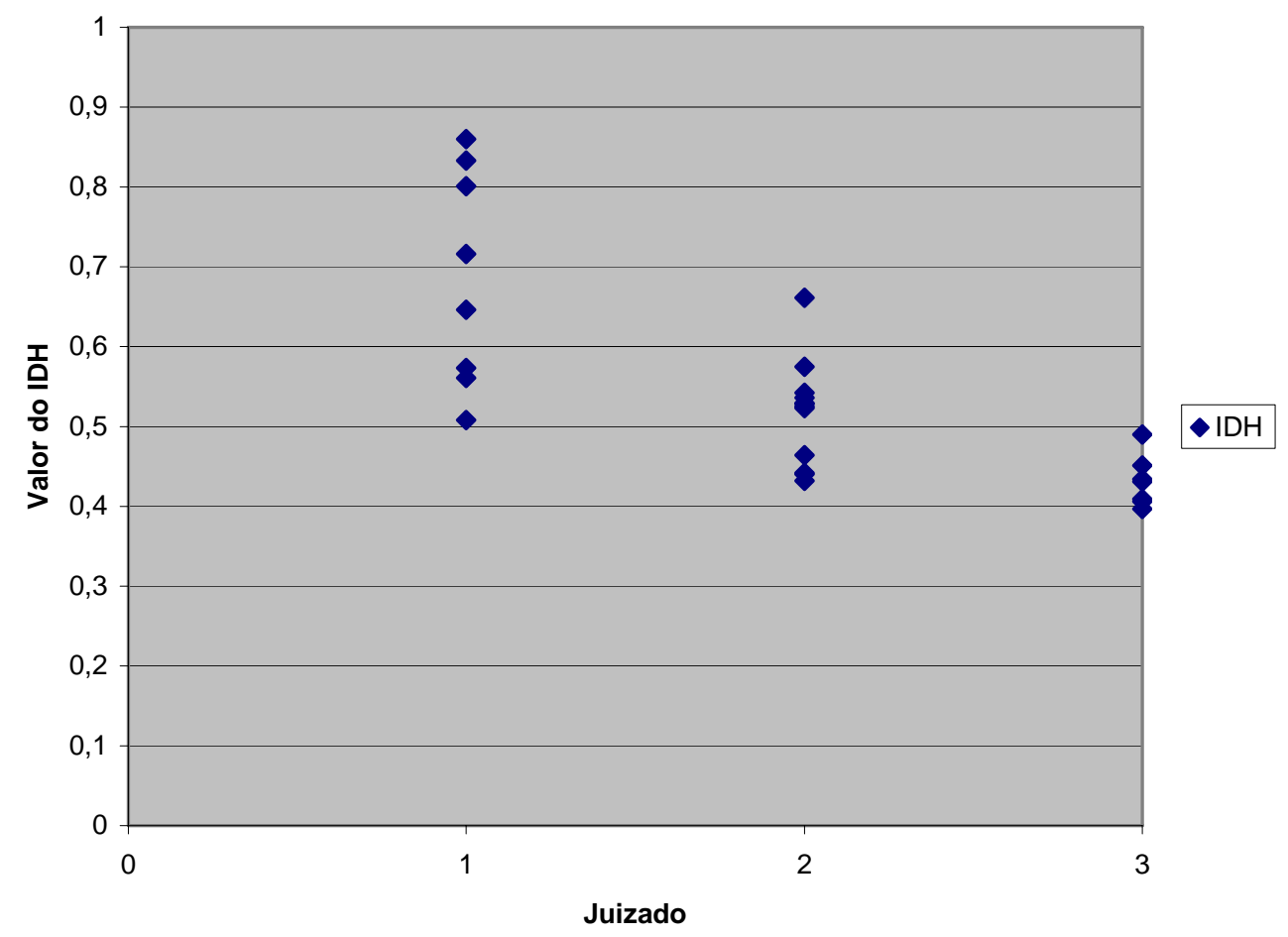

Fonte: Secretaria do Desenvolvimento, Trabalho e Solidariedade - PMSP, 2000.

Observa-se que os distritos atendidos pelo CIC - Leste apresentam os menores valores de IDH, bem como os mais concentrados, na faixa de 0,400 a 0,500. As maiores posições são ocupadas pelos distritos atendidos no Juizado de Pinheiros, que, entretanto, abrangem índices de IDH que vão da faixa de 0,500 até 0,900. Já os distritos atendidos pelo CIC - Oeste encontram-se em uma posição média de IDH, variando das faixas de 0,500 a 0,700 .

Portanto, de um modo geral, podemos afirmar que estas três regiões, mesmo sem apresentar diferenças relevantes no perfil de idade, apresentam significativa diferença em termos de renda per capita. Estes dados somados às observações das posições relativas do IDH permitem inferir que a região atendida pelo Fórum de Pinheiros localiza-se em uma posição mais rica e com maiores valores de IDH, seguida pelo CIC Oeste, e, como região mais pobre e de menores valores de IDH, temos a região atendida pelo CIC Leste.

Diante deste quadro, passaremos a analisar os resultados da pesquisa de campo e o teste das hipóteses no próximo item. 


\subsection{Resultados da Pesquisa}

No presente item são descritos os principais resultados encontrados na pesquisa de campo. Primeiramente serão descritos os aspectos gerais da distribuição de feitos nos Juizados pesquisados. Após analisaremos os resultados encontrados para os tipos de reclamante, os tipos de ação e, por fim, os dados sobre os tipos de reclamado, para averiguarmos as hipóteses levantadas.

Na tabela 15 abaixo, indicamos o movimento anual total dos Juizados pesquisados, desde sua instalação até a data de 11/11/2005. Esses resultados estão discriminados também no gráfico 03.

Tabela 15: Total de Feitos Distribuídos nos Juizados Especiais Pesquisados - Número e Percentual de Variação Anual

\begin{tabular}{c|cc|cc|cc|cc}
\multicolumn{2}{c}{ Ano } & \multicolumn{2}{c}{ Pinheiros } & \multicolumn{2}{c}{ CIC - Oeste } & \multicolumn{2}{c}{ CIC - Leste } & \multicolumn{2}{c}{ Total } \\
\hline \hline & N & Variação Anual & N Variação Anual & \multicolumn{1}{c}{ N } & Variação Anual & \multicolumn{2}{c}{ N } & Variação Anual \\
1995 & 359 & ------ & ---- & ------ & ---- & ------- & 359 & \\
1996 & 1202 & 234,82 & ---- & ------ & ---- & ------ & 1202 & 234,82 \\
1997 & 1306 & 8,65 & ---- & ------ & ---- & ------ & 1306 & 8,65 \\
1998 & 1570 & 20,21 & ---- & ------ & ---- & ------ & 1570 & 20,21 \\
1999 & 2247 & 43,12 & 564 & ------ & ---- & ------ & 2811 & 79,04 \\
2000 & 2765 & 23,05 & 911 & 61,52 & ---- & ------- & 3676 & 30,77 \\
2001 & 2818 & 1,92 & 807 & $-11,42$ & ---- & ------ & 3625 & $-1,39$ \\
2002 & 3834 & 36,05 & 814 & 0,87 & ---- & ------ & 4648 & 28,22 \\
2003 & 4107 & 7,12 & 751 & $-7,74$ & 1245 & ------- & 6103 & 31,30 \\
2004 & 3700 & $-9,91$ & 744 & $-0,93$ & 1452 & 16,63 & 5896 & $-3,39$ \\
2005 & 3563 & $-3,70$ & 991 & 33,20 & 4945 & 240,56 & 9499 & 61,11 \\
\hline
\end{tabular}

Fonte: Pesquisa de Campo, Erik Macedo Marques - 2006 


\section{Gráfico 03}

\section{Número de Processos Distribuídos nos JEC's Pesquisados e Total nos Anos de 1995 a 2005}

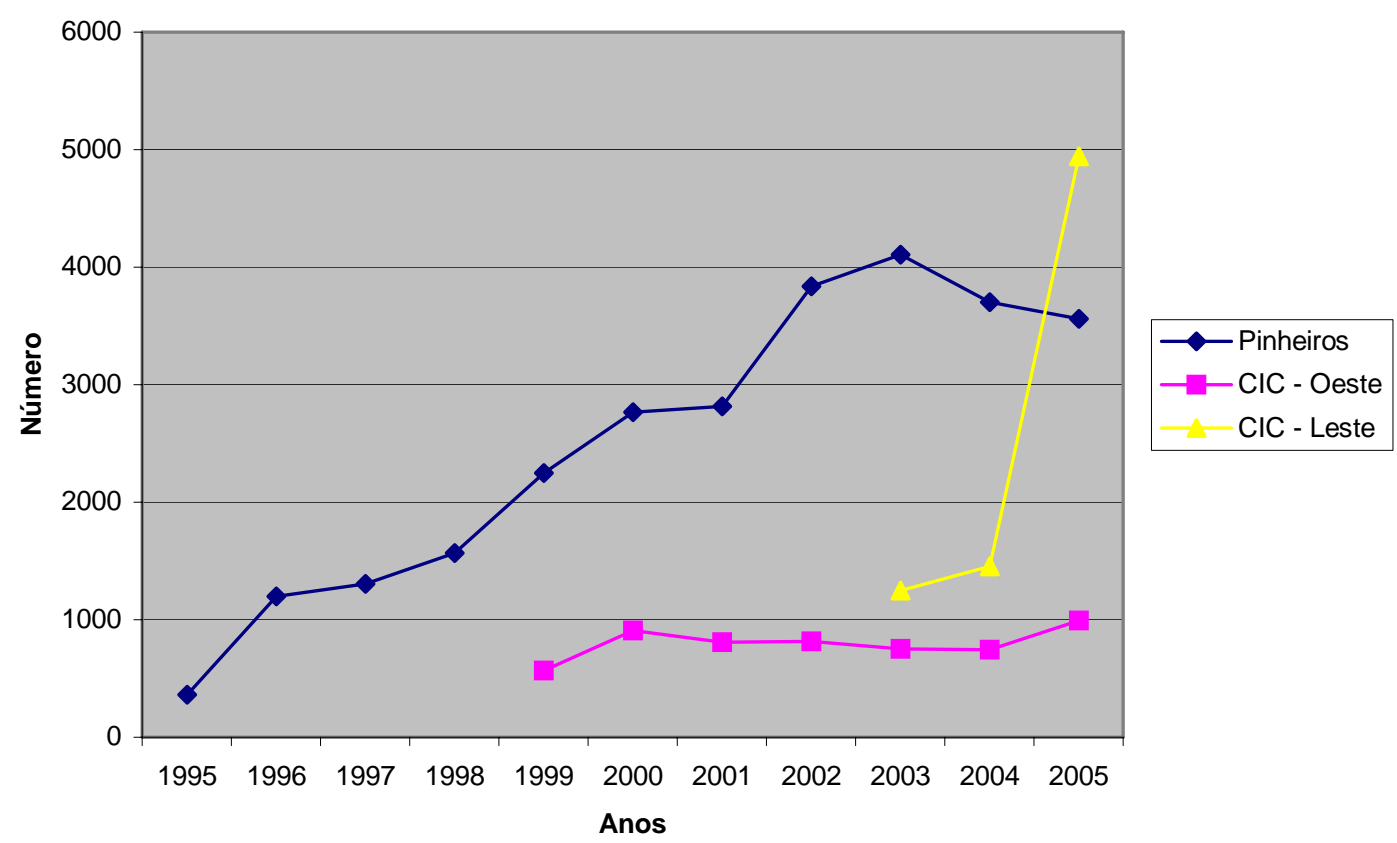

Fonte: Pesquisa de Campo, Erik Macedo Marques - 2006

Dos três Juizados Pesquisados, o mais antigo é o Juizado do Fórum de Pinheiros. Este Juizado também é o que apresenta, com exceção do ano de 2005, os maiores volumes de feitos distribuídos. Nota-se também crescimento expressivo do número de feitos distribuídos no ano de 1996 (234,8\% de variação anual), mas isto se deve à data de sua instalação em agosto de 1995. Crescimentos anuais relevantes são observados nos anos de 1998, 1999, 2000 e 2002, com percentuais de variação respectivos de 20,2\%; 43,1\% (segundo maior crescimento da série); $23,1 \%$ e 36,1\%. O maior valor numérico de feitos distribuídos na série ocorre em 2003, com 4.107 feitos distribuídos. Apresenta também decréscimos de 9,9\% e 3,7\% nos anos de 2004 e 2005, encerrando a série com 3.563 feitos distribuídos.

O Juizado do CIC Oeste possui os menores valores de distribuição anual de feitos, nunca acima da faixa até 1.000 processos por ano. Inicia a série em 1999, sofrendo grandes acréscimos nos anos de 2000 (crescimento de 61,52\%, e também ano posterior a sua inauguração), e em 2005, com acréscimo de 33,2\% de feitos distribuídos. Apresenta decréscimos em sua distribuição nos anos de 2001, 2003 e 2004, com quedas de 
11,4\%; 7,7\% e 0,9\% respectivamente. Interessante notar que em sete anos de existência, este JEC apresentou dois anos de crescimento e dois anos de decréscimos, mantendo-se praticamente estável a distribuição de feitos nos anos de 2002 e 2004.

O Juizado que realiza os seus atendimentos no CIC Leste, apesar de sua inauguração ocorrer apenas em $2003^{24}$, apresenta valores maiores de distribuição que o CIC Oeste nos anos de 2003 a 2005, e, neste último ano, é o Juizado com o maior valor de distribuição dos três pesquisados: 4.945, com o maior valor de variação anual: 240,6\%.

Constata-se na observação destes dados que não há como apontarmos uma relação direta entre a situação sócio-econômica da região atendida e a quantidade de feitos distribuídos, dado que o CIC Oeste, que se encontra em uma situação intermediária dos três pesquisados, é o que apresenta a menor distribuição em todos os anos da série. Apesar do Fórum de Pinheiros apresentar, durante a maior parte da série, os maiores valores, no ano de 2005, o Juizado que apresenta a maior distribuição é o de pior situação sócio-econômica, CIC Leste.

Abaixo apresentamos a tabela 16 e o gráfico 04, que indicam o número e percentual de autores por tipo. Observa-se que o número de autores é diverso do apresentado pelo número de feitos pesquisados na amostra, e isto se deve aos litisconsórcios ativos, termo jurídico que define a presença de mais de um autor movendo a ação ${ }^{25}$.

Tabela 16: Tipo de Autor por Juizado Pesquisado - Número e Percentual

\begin{tabular}{l|cc|cc|cc|cc}
\hline Tipo de Autor & \multicolumn{2}{c}{ CIC - Leste } & \multicolumn{2}{c}{ CIC - Oeste } & \multicolumn{2}{c}{ Pinheiros } & \multicolumn{2}{c}{ Total } \\
\hline Condomínio & $\mathrm{N}$ & $\%$ & $\mathrm{~N}$ & $\%$ & $\mathrm{~N}$ & $\%$ & Não & $\%$ \\
Micro Empresa & 10 & 1,49 & 2 & 0,38 & 0 & 0,00 & 12 & 0,52 \\
Pessoa Física & 65 & 0,75 & 47 & 8,90 & 24 & 2,20 & 76 & 3,32 \\
Total & 97,76 & 479 & 90,72 & 1065 & 97,80 & 2200 & 96,15 \\
\hline & 671 & 100,00 & 528 & 100,00 & 1089 & 100,00 & 2288 & 100,00 \\
\hline
\end{tabular}

\footnotetext{
${ }^{24}$ Cabe observar que desde 1996 havia nas instalações do CIC Leste o Juizado Informal de Conciliação.
} 


\section{Gráfico 04}

Percentual de Tipos de Autor por Juizado Especial

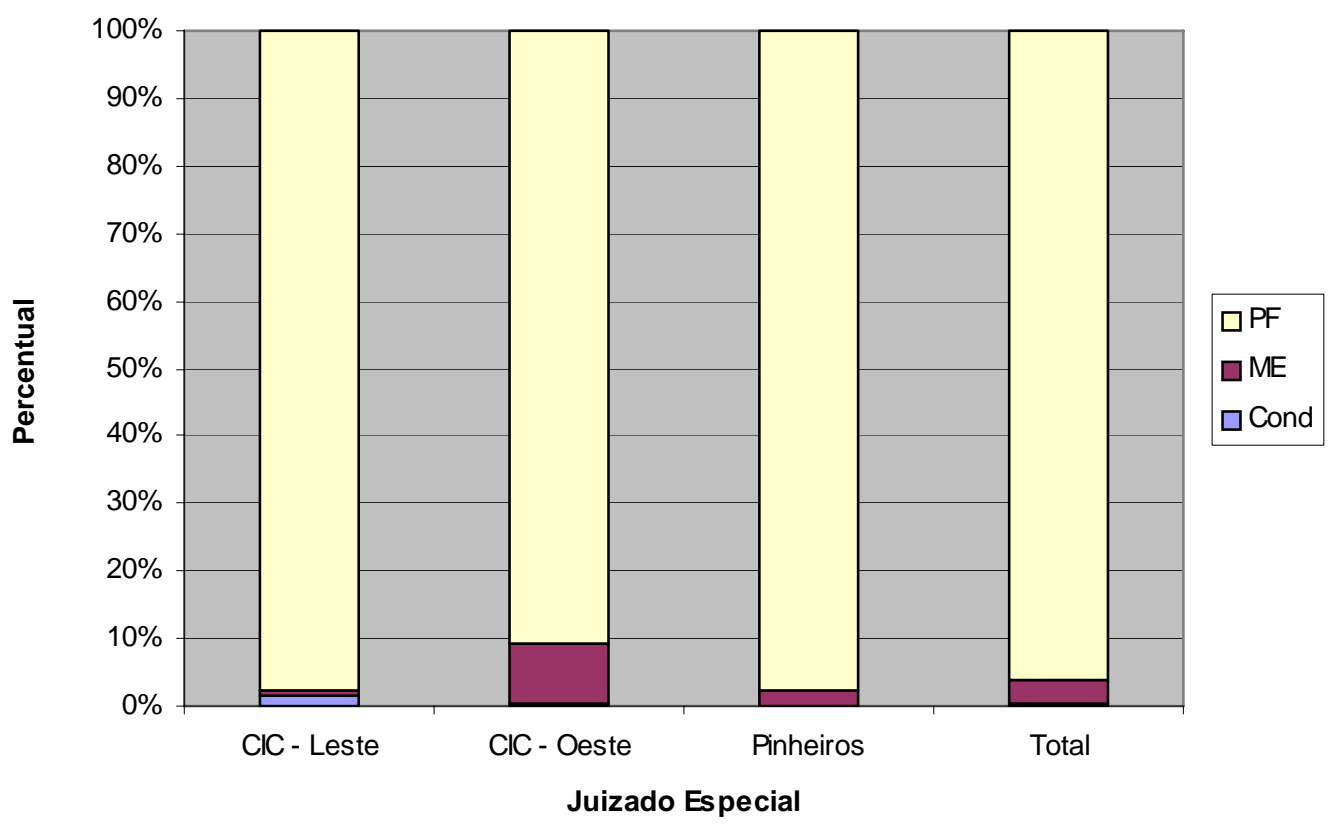

Fonte: Pesquisa de Campo, Erik Macedo Marques - 2006

A primeira nota a ser feita deve-se à presença de condomínios como autores de ação nos Juizados do CIC Leste e CIC Oeste. Para Chimenti (2005),

“Os condomínios formalizados e demais entidades denominadas 'não personalizadas', ou 'universalidades de direitos' (massa falida, consórcio etc.), não têm legitimidade para figurar no pólo ativo das ações que tramitam perante os Juizados Especiais Cíveis, já que o objetivo maior do novo sistema é defender os direitos do cidadão, pessoa física”

E prossegue:

${ }^{25}$ Conforme a definição de litisconsórcio em Cintra et alli (2006 pp. 314 e 315). O artigo 10 da Lei 9.099/95 dispõe que: "Não se admitirá, no processo, qualquer forma de intervenção de terceiro nem de assistência.

Admitir-se-á o litisconsórcio.” (Grifo nosso). Para a análise deste artigo, ver, Chimento (2005, pp.112 e 113). 
“Os condomínios regularmente constituídos não poderão ingressar no Juizado, pois descumpririam os termos expressos do art. $8^{\circ}, \S 1^{\circ}$, além de abarrotarem os Juizados Especiais, que vieram para ampliar o acesso à Justiça daqueles que ficavam privados do ingresso em juízo de seus pleitos - o que nunca ocorreu com os condomínios de edifício”(pp. 112 e 113)

A posição do autor é corroborada pelo Enunciado 14 do I Encontro de Juízes Coordenadores de Juizados da Capital e de Anexos de Juizados em Faculdades de Direito, em São Paulo, agosto de 2000:

“Não é admitido condomínio como autor no Sistema dos Juizados Especiais”

Em posição contrária, temos o Enunciado 9 do FONAJE (Fórum Nacional dos Juizados Especiais), que dispõe:

“O condomínio residencial poderá propor ação no Juizado Especial, nas hipóteses do art. 275, II, b, do CPC”.

A alínea citada dispõe sobre as ações contra condômino para a cobrança de quantias devidas ao condomínio. Observa-se que não há uma posição fixa na doutrina jurídica para a presença ou não de condomínios no pólo ativo da demandas.

Durante a pesquisa de campo no mês de abril, o Juiz Diretor do Juizado Especial do CIC Leste nos informou que os condomínios da região cobram, em média, R\$ 40,00 por mês de seus moradores. Dado o valor cobrado pelos condomínios, as ações contra seus devedores se ingressadas na Justiça Comum tornam o processo caro frente ao débito a ser recebido. Mas, mesmo sendo valores relativamente baixos, são essenciais para a administração dos prédios da região. Assim, no entendimento deste Juiz, há a necessidade de se aceitar que nesta região os condomínios utilizem-se do Juizado Especial para ter a quantia devida reavida. Privá-los do acesso ao JEC seria privá-los do acesso a resolução de seus conflitos por todo o sistema judiciário. 
A presença de condomínios como autores dos JEC's é também inconstante quando se observa diferentes Estados da federação. Conforme pesquisa do Centro Brasileiro de Estudos e Pesquisas Judiciais - CEBEPEJ em 2006, os condomínios não são autores no Amapá, em Minas Gerais, e em São Paulo (neste Estado, conforme os dados coletados, não podemos generalizar esta afirmação para todos os Juizados). São aceitos com restrições em Goiás, e no Rio Grande do Sul; e são aceitos sem nenhum óbice nos Estados da Bahia, Ceará, Pará e Rio de Janeiro ${ }^{26}$.

A constatação destes condomínios como autores nos JEC's não somente em Juizados de diferentes Estados, mas principalmente em Juizados localizados na mesma comarca, a par dos seus motivos, nos dá um grande indício acerca do afirmado por Vianna et alli (1999, p. 112): “... cada Juizado é o império do juiz, seguindo, em regra, o seu estilo de gerência e de prestação jurisdicional ...”.

$\mathrm{Na}$ amostra pesquisada, localizamos 12 ações movidas por condomínios nos Juizados dos CIC’s. Os tipos de reclamados dessas ações foram em grande parte do tipo pessoa física, a exceção é uma ação de Condenação em Dinheiro em 2004 movida contra uma empresa de administração de água no Juizado do CIC Leste. No CIC Oeste as duas ações encontradas foram de Condenação em Dinheiro, e, no CIC Leste, as ações foram de Condenação em Dinheiro (6 ações) e 4 de Execução de Título Judicial em 2003, o que indica também a utilização do Juizado Informal de Conciliação por este tipo de autor.

Analisando a tabela 16 e o gráfico 04 acima, observamos que em todos os Juizados pesquisados o tipo de autor mais freqüente é Pessoa Física, que representa 96,15\% do total de autores na amostra. Este dado nos permite, junto com as outras pesquisas já relacionadas, aceitar a Hipótese 1 acima arrolada: nos Juizados Especiais Cíveis, o tipo de autor mais freqüente é pessoa física.

A maior participação percentual de pessoas físicas como autores ocorreu no Juizado do Fórum de Pinheiros, com 97,8\% (1.065 ocorrências). Seguido do CIC Leste, com 97,8\% (656 ocorrências) e do CIC Oeste, com a menor participação percentual de 90,7\% (479 ocorrências).

As Micro-Empresas, conforme definição do inciso I do art. $2^{\circ}$ da Lei 9.841/99, são pessoas jurídicas ou firmas individuais que têm receita bruta anual de até R\$

\footnotetext{
${ }^{26}$ Ministério da Justiça/CEBEPEJ, Juizados Especiais Cíveis: Estudo, Brasília, 2006, pp. 23 e 24.
} 
244.000,00. Este tipo de pessoa jurídica passou a ser admitido como autor nos Juizados Especiais a partir da Lei 9.841/99.

Em toda a amostra pesquisada, encontramos apenas 3,3\% (76 ocorrências) de Micro-Empresas como autoras nas ações. A maior participação percentual foi no Juizado do CIC Oeste, com 8,9\%, 47 ocorrências. No Juizado de Pinheiros encontramos 2,2\% de participação desse tipo de autor (24 ocorrências), e a menor participação percentual foi encontrada no Juizado do CIC Leste, com apenas 0,7\% (5 ocorrências), menor que a participação de Condomínios como autor nesse mesmo JEC.

A seguir especificamos a participação desses tipos de autor por ano pesquisado no Juizado do CIC Leste:

Tabela 17: Tipos de Autor do Juizado Especial do CIC Leste - Número e Percentual

\begin{tabular}{c|cc|cc|cc|cc}
\hline \multicolumn{2}{c}{ CIC Leste } & \multicolumn{2}{c}{2003} & \multicolumn{2}{c}{2004} & \multicolumn{2}{c}{ Total } \\
\hline \hline & $\mathrm{N}$ & $\%$ & Não & $\%$ & $\mathrm{~N}$ & $\%$ & $\mathrm{~N}$ & $\%$ \\
Condomínio & 8 & 6,50 & 1 & 0,68 & 1 & 0,25 & 10 & 1,49 \\
Micro Empresa & 1 & 0,81 & 1 & 0,68 & 3 & 0,75 & 5 & 0,75 \\
Pessoa Física & 114 & 92,68 & 144 & 98,63 & 398 & 99,00 & 656 & 97,76 \\
Total & 123 & 100,00 & 146 & 100,00 & 402 & 100,00 & 671 & 100,00 \\
\hline \hline
\end{tabular}

Neste Juizado houve um constante crescimento da participação percentual do tipo Pessoa Física, que de 92,68\% de participação em 2003 passou para 99\% em 2005. O maior decréscimo observado foi com relação ao tipo Condomínio que, de 8 ações na amostra de 2003, apenas esteve presente em um caso no ano de 2004 e um caso no ano de 2005. As Micro-Empresas pouco participaram desde o início da série, com apenas 1 caso para o ano de 2003, outro para 2004 e 3 casos em 2005.

Abaixo apresentamos a tabela 18, com o número e o percentual por ano para o Juizado do CIC Oeste:

Tabela 18: Tipos de Autor do Juizado Especial do CIC Oeste - Número e Percentual

\begin{tabular}{|c|c|c|c|c|c|c|}
\hline \multirow[t]{2}{*}{ CIC Oeste } & \multicolumn{2}{|c|}{2000} & \multicolumn{2}{|c|}{2001} & \multicolumn{2}{|c|}{2002} \\
\hline & $\mathrm{N}$ & $\%$ & $\mathrm{~N}$ & $\%$ & $\mathrm{~N}$ & $\%$ \\
\hline Micro Empresa & 2 & 2,08 & 7 & 8,33 & 12 & 13,79 \\
\hline Pessoa Física & 94 & 97,92 & 77 & 91,67 & 75 & 86,21 \\
\hline Total & 96 & 100,00 & 84 & 100,00 & 87 & 100,00 \\
\hline
\end{tabular}


Continuação da Tabela 18: Tipos de Autor do Juizado Especial do CIC Oeste - Número e Percentual

\begin{tabular}{c|cc|cc|cc|cc}
\hline \multicolumn{1}{c}{ CIC Oeste } & \multicolumn{2}{c}{2003} & \multicolumn{2}{c}{2004} & \multicolumn{2}{c}{2005} & \multicolumn{2}{c}{ Total } \\
\hline \hline & $\mathrm{N}$ & $\%$ & $\mathrm{~N}$ & $\%$ & $\mathrm{~N}$ & $\%$ & $\mathrm{~N}$ & $\%$ \\
Condomínio & & & & & 2 & 1,98 & 2 & 0,38 \\
Micro Empresa & 7 & 8,54 & 5 & 6,25 & 14 & 13,86 & 47 & 8,87 \\
Pessoa Física & 75 & 91,46 & 75 & 93,75 & 85 & 84,16 & 481 & 90,75 \\
Total & 82 & 100,00 & 80 & 100,00 & 101 & 100,00 & 530 & 100,00 \\
\hline \hline
\end{tabular}

Fonte: Pesquisa de Campo, Erik Macedo Marques - 2006

O tipo de autor Pessoa Física tem a maior participação percentual em todos os anos pesquisados. O seu maior índice ocorre no ano de 2000, primeiro ano da série, com 97,9\%. Em 2005, último ano, ocorre a menor participação, 84,2\%. Observa-se, apesar de oscilações, uma tendência de decréscimo do percentual deste tipo de autor na série. A esta tendência, soma-se o crescimento de Micro-Empresas, que, de 2,1\% em 2000, participa em 2005 com 13,9\%, o seu maior índice na série. A participação de Condomínio ocorre apenas no ano de 2005, com 2 casos.

A seguir apresentamos a tabela 19, de número e percentual de tipo de autor por ano para o JEC do Fórum de Pinheiros.

Tabela 19: Tipos de Autor do Juizado Especial de Pinheiros - Número e Percentual

\begin{tabular}{c|cc|cc|cc}
\hline \multicolumn{1}{c|}{ Pinheiros } & $\mathrm{N}$ & $\%$ & $\mathrm{~N}$ & $\%$ & $\mathrm{~N}$ & $\%$ \\
\hline \hline & 1 & 0,71 & 2 & 1,31 & 4 & 1,98 \\
Micro Empresa & 1 & 99,29 & 151 & 98,69 & 198 & 98,02 \\
Pessoa Física & 140 & 100,00 & 153 & 100,00 & 202 & 100,00 \\
Total & 141 & \multicolumn{3}{c}{ Fonte: Pesquisa de Campo, Erik Macedo Marques - 2006 }
\end{tabular}

Continuação da Tabela 19: Tipos de Autor do Juizado Especial de Pinheiros - Número e Percentual

\begin{tabular}{c|cc|cc|cc|cc}
\hline \multicolumn{2}{c}{2003} & \multicolumn{2}{c}{2004} & \multicolumn{2}{c}{2005} & \multicolumn{2}{c}{ Total } \\
\hline \hline Pinheiros & $\mathrm{N}$ & $\%$ & Não & $\%$ & $\mathrm{~N}$ & $\%$ & Não & $\%$ \\
Micro Empresa & 5 & 2,28 & 2 & 1,06 & 10 & 5,41 & 24 & 2,20 \\
Pessoa Física & 214 & 97,72 & 187 & 98,94 & 175 & 94,59 & 1065 & 97,80 \\
Total & 219 & 100,00 & 189 & 100,00 & 185 & 100,00 & 1089 & 100,00 \\
\hline \hline
\end{tabular}

Para este Juizado, no qual não são aceitos condomínios no pólo ativo da demanda, o tipo de autor Pessoa Física representa 97,8\% dos autores. O maior valor percentual ocorre em 2000, com 99,3\%, e o menor valor ocorre em 2005, com 94,59\%. Há 
uma leve tendência de queda na participação percentual desse tipo de autor, correspondendo um leve crescimento percentual de participação das Micro-Empresas.

A seguir analisaremos os tipos de ação que ingressaram nos Juizados pesquisados. Abaixo, a tabela 20 indica a freqüência e o percentual de feitos por tipo de ação no Juizado Especial do CIC Leste:

Tabela 20: Tipos de Ação no Juizado Especial do CIC Leste - Número e Percentual

\begin{tabular}{|c|c|c|c|c|c|c|c|c|}
\hline CIC Leste & \multicolumn{2}{|c|}{2003} & \multicolumn{2}{|c|}{2004} & \multicolumn{2}{|c|}{2005} & \multicolumn{2}{|c|}{ Total } \\
\hline & $\mathrm{N}$ & $\%$ & $\mathrm{~N}$ & $\%$ & $\mathrm{~N}$ & $\%$ & $\mathrm{~N}$ & $\%$ \\
\hline Condenação em Dinheiro & 27 & 21,95 & 23 & 15,75 & 50 & 12,44 & 100 & 14,90 \\
\hline $\begin{array}{c}\text { Condenação ao } \\
\text { Cumprimento de } \\
\text { Obrigação de Fazer ou Não }\end{array}$ & 14 & 1128 & 21 & 1428 & 10 & 095 & 75 & 1118 \\
\hline Execução Título Judicial & 26 & 21,14 & 26 & 17,81 & 17 & 4,23 & 69 & 10,28 \\
\hline $\begin{array}{c}\text { Reparação de Danos (em } \\
\text { geral) }\end{array}$ & 12 & 9,76 & 16 & 10,96 & 20 & 4,98 & 48 & 7,15 \\
\hline $\begin{array}{l}\text { Desconstituição de } \\
\text { Contrato }\end{array}$ & 10 & 8,13 & 14 & 9,59 & 18 & 4,48 & 42 & 6,26 \\
\hline $\begin{array}{l}\text { Execução Título Extra- } \\
\text { Judicial }\end{array}$ & 17 & 13,82 & 13 & 8,90 & 12 & 2,99 & 42 & 6,26 \\
\hline Declaratória (em geral) & 2 & 1,63 & 8 & 5,48 & 20 & 4,98 & 30 & 4,47 \\
\hline $\begin{array}{c}\text { Ressarcimento de Danos } \\
\text { Causados em Acidente de } \\
\text { Veículo }\end{array}$ & 4 & 3,25 & 5 & 3,42 & 15 & 3,73 & 24 & 3,58 \\
\hline $\begin{array}{c}\text { Condenação à Entrega de } \\
\text { Coisa Certa }\end{array}$ & 2 & 1,63 & 5 & 3,42 & 4 & 1,00 & 11 & 1,64 \\
\hline Despejo & 1 & 0,81 & 1 & 0,68 & 2 & 0,50 & 4 & 0,60 \\
\hline $\begin{array}{l}\text { Declaração de Nulidade de } \\
\text { Contrato }\end{array}$ & 1 & 0,81 & 1 & 0,68 & 0 & 0,00 & 2 & 0,30 \\
\hline Homologação & 0 & 0,00 & 1 & 0,68 & 0 & 0,00 & 1 & 0,15 \\
\hline Medida Cautelar & 0 & 0,00 & 1 & 0,68 & 0 & 0,00 & 1 & 0,15 \\
\hline Sustação de Protesto & 0 & 0,00 & 0 & 0,00 & 1 & 0,25 & 1 & 0,15 \\
\hline $\begin{array}{c}\text { Outros feitos não } \\
\text { especificados }\end{array}$ & 7 & 5,69 & 11 & 7,53 & 203 & 50,50 & 221 & 32,94 \\
\hline Total & 123 & 100,00 & 146 & 100,00 & 402 & 100,00 & 671 & 100,00 \\
\hline
\end{tabular}

Fonte: Pesquisa de Campo, Erik Macedo Marques - 2006

O tipo de ação "Outros feitos não especificados” tem a maior participação percentual neste Juizado: no total representa 32,94\% dos feitos da amostra, e, só no ano de 2005 é responsável por 50,5\% dos processos entrados no Juizado. Neste ano específico, todas as ações deste tipo foram movidas por Pessoa Física, 197 ações da amostra, foram contra Pessoa Jurídica - Concessionária de Telefonia. Estas ações foram em razão da 
cobrança de assinatura de linha telefônica. Os cartorários do Juizado do CIC Leste afirmaram que, durante 2005, filas formavam-se em frente ao JEC no horário da manhã para a distribuição dessas ações, feitas normalmente por pessoas físicas sem o acompanhamento de advogados. Mesmo informando as pessoas sobre a baixa possibilidade de se ganhar a ação, bem como a existência de ação civil pública movida pelo Ministério Público com o mesmo objeto, e que tal ação teria o efeito de alcançá-los em sua decisão também, grande parte das pessoas que para lá acorreram decidiram ingressar com a ação. Na pesquisa observamos que em 2006 aguardavam a distribuição processos dessa natureza que ingressaram em 2005.

O segundo tipo de ação mais freqüente neste Juizado foi “Condenação em Dinheiro”, representando 14,9\% dos feitos deste JEC, participando no ano de 2003 com $21,9 \%$.

O tipo "Condenação ao Cumprimento de Obrigação de Fazer ou Não Fazer” representa 11,18\% do total de ações da amostra desse Juizado. O seu maior percentual foi no ano de 2004, com $14,4 \%$.

O tipo de ação "Execução de Título Judicial” aparece em 10,3\% dos casos da amostra. No ano de 2004 é o tipo de ação com maior participação percentual, 17,8\%. A grande presença desse tipo de ação no Juizado deve-se à existência anterior do Juizado Informal de Conciliação, cuja competência não permite a execução de seus acordos. Com a instalação do Juizado Especial Cível, os acordos realizados no antigo JIC e não cumpridos passaram a ser levados novamente às portas judiciais para a sua execução, o que explica a sua grande participação na amostra pesquisada deste JEC, ao contrários dos outros.

A seguir apresentamos a tabela dos tipos de ação do Juizado Especial do Juizado do CIC Oeste: 
Tabela 21: Tipos de Ação no Juizado Especial do CIC Oeste - Número e Percentual

\begin{tabular}{|c|c|c|c|c|c|c|}
\hline \multirow[t]{2}{*}{ CIC Oeste } & \multicolumn{2}{|c|}{2000} & \multicolumn{2}{|c|}{2001} & \multicolumn{2}{|c|}{2002} \\
\hline & $\mathrm{N}$ & $\%$ & $\overline{\mathrm{N}}$ & $\%$ & Não & $\%$ \\
\hline Condenação em Dinheiro & 44 & 46,81 & 40 & 48,19 & 33 & 39,29 \\
\hline Execução Título Extra-Judicial & 18 & 19,15 & 15 & 18,07 & 14 & 16,67 \\
\hline $\begin{array}{c}\text { Ressarcimento de Danos } \\
\text { Causados em Acidente de } \\
\text { Veículo }\end{array}$ & 8 & 8,51 & 11 & 13,25 & 16 & 19,05 \\
\hline $\begin{array}{l}\text { Condenação ao Cumprimento de } \\
\text { Obrigação de Fazer ou Não Fazer }\end{array}$ & 7 & 7,45 & 9 & 10,84 & 9 & 10,71 \\
\hline Reparação de Danos (em geral) & 7 & 7,45 & 3 & 3,61 & 8 & 9,52 \\
\hline Desconstituição de Contrato & 8 & 8,51 & 5 & 6,02 & 1 & 1,19 \\
\hline Declaratória (em geral) & 0 & 0,00 & 0 & 0,00 & 1 & 1,19 \\
\hline Outros feitos não especificados & 1 & 1,06 & 0 & 0,00 & 2 & 2,38 \\
\hline Embargos de Terceiros & 1 & 1,06 & 0 & 0,00 & 0 & 0,00 \\
\hline Total & 94 & 100,00 & 83 & 100,00 & 84 & 100,00 \\
\hline
\end{tabular}

Fonte: Pesquisa de Campo, Erik Macedo Marques - 2006

Continuação da Tabela 21: Tipos de Ação no Juizado Especial do CIC Oeste - Número e Percentual

\begin{tabular}{|c|c|c|c|c|c|c|c|c|}
\hline \multirow[t]{2}{*}{ Tipo de Ação } & \multicolumn{2}{|c|}{2003} & \multicolumn{2}{|c|}{2004} & \multicolumn{2}{|c|}{2005} & \multicolumn{2}{|c|}{ Totais } \\
\hline & $\mathrm{N}$ & $\%$ & $\mathrm{~N}$ & $\%$ & $\mathrm{~N}$ & $\%$ & $\mathrm{~N}$ & $\%$ \\
\hline Condenação em Dinheiro & 34 & 43,04 & 31 & 39,74 & 39 & 39,39 & 221 & 42,75 \\
\hline $\begin{array}{l}\text { Execução Título Extra- } \\
\text { Judicial }\end{array}$ & 13 & 16,46 & 15 & 19,23 & 13 & 13,13 & 88 & 17,02 \\
\hline $\begin{array}{l}\text { Ressarcimento de Danos } \\
\text { Causados em Acidente de } \\
\text { Veículo } \\
\end{array}$ & 15 & 18,99 & 7 & 8,97 & 20 & 20,20 & 77 & 14,89 \\
\hline $\begin{array}{c}\text { Condenação ao } \\
\text { Cumprimento de } \\
\text { Obrigação de Fazer ou } \\
\text { Não Fazer } \\
\end{array}$ & 5 & 6,33 & 9 & 11,54 & 8 & 8,08 & 47 & 9,09 \\
\hline $\begin{array}{l}\text { Reparação de Danos (em } \\
\text { geral) }\end{array}$ & 7 & 8,86 & 6 & 7,69 & 11 & 11,11 & 42 & 8,12 \\
\hline $\begin{array}{l}\text { Desconstituição de } \\
\text { Contrato }\end{array}$ & 0 & 0,00 & 1 & 1,28 & 5 & 5,05 & 20 & 3,87 \\
\hline Declaratória (em geral) & 3 & 3,80 & 8 & 10,26 & 1 & 1,01 & 13 & 2,51 \\
\hline $\begin{array}{l}\text { Outros feitos não } \\
\text { especificados }\end{array}$ & 1 & 1,27 & 1 & 1,28 & 2 & 2,02 & 7 & 1,35 \\
\hline Despejo & 1 & 1,27 & 0 & 0,00 & 0 & 0,00 & 1 & 0,19 \\
\hline Embargos de Terceiros & 0 & 0,00 & 0 & 0,00 & 0 & 0,00 & 1 & 0,19 \\
\hline Total & 79 & 100,00 & 78 & 100,00 & 99 & 100,00 & 517 & 100,00 \\
\hline
\end{tabular}

Fonte: Pesquisa de Campo, Erik Macedo Marques - 2006

Neste Juizado o tipo de ação mais freqüente encontrado na amostra foi “Condenação em Dinheiro”, com 42,8\%. Em todos os anos da série este tipo de ação é 
responsável por mais de 39\% das ações da amostra, e, no ano de 2001 alcança o seu maior valor, 48,2\%. O segundo tipo de ação mais freqüente é “Execução de Título Extra-Judicial”, que representa $17 \%$ do total de ações da amostra, e, no ano de 2000 tem a sua maior participação: 19,2\%. Cabe esclarecer que este tipo de demanda refere-se à cobrança forçada de títulos extra-judiciais, como cheques e notas promissórias, e o seu procedimento não exige maiores atos de produção de prova para o Juízo, basta a apresentação da cártula em que consta o débito.

Com 14,9\%, o tipo de ação "Ressarcimento em Danos Causados em Acidente de Veículos” é o terceiro tipo mais freqüente, e sua maior participação percentual ocorre em 2005, com 20,2\% das ações constantes da amostra deste ano.

A seguir apresentamos a tabela 22, com número e percentual de tipo de ação para o Juizado de Pinheiros.

Tabela 22: Tipos de Ação no Juizado Especial de Pinheiros - Número e Percentual

\begin{tabular}{|c|c|c|c|c|c|c|}
\hline Pinheiros & \multicolumn{2}{|c|}{2000} & \multicolumn{2}{|c|}{2001} & \multicolumn{2}{|c|}{2002} \\
\hline & $\mathrm{N}$ & $\%$ & $\mathrm{~N}$ & $\%$ & $\mathrm{~N}$ & $\%$ \\
\hline Condenação em Dinheiro & 44 & 31,65 & 52 & 36,88 & 56 & 29,02 \\
\hline $\begin{array}{c}\text { Condenação ao Cumprimento } \\
\text { de Obrigação de Fazer ou Não } \\
\text { Fazer }\end{array}$ & 20 & 14,39 & 14 & 9,93 & 40 & 20,73 \\
\hline $\begin{array}{c}\text { Reparação de Danos (em } \\
\text { geral) }\end{array}$ & 16 & 11,51 & 18 & 12,77 & 26 & 13,47 \\
\hline $\begin{array}{c}\text { Ressarcimento de Danos } \\
\text { Causados em Acidente de } \\
\text { Veículo } \\
\end{array}$ & 34 & 24,46 & 24 & 17,02 & 27 & 13,99 \\
\hline Desconstituição de Contrato & 12 & 8,63 & 15 & 10,64 & 23 & 11,92 \\
\hline $\begin{array}{l}\text { Outros feitos não } \\
\text { especificados }\end{array}$ & 2 & 1,44 & 10 & 7,09 & 10 & 5,18 \\
\hline $\begin{array}{l}\text { Execução Título Extra- } \\
\text { Judicial }\end{array}$ & 11 & 7,91 & 8 & 5,67 & 7 & 3,63 \\
\hline $\begin{array}{l}\text { Declaração de Nulidade de } \\
\text { Contrato }\end{array}$ & 0 & 0,00 & 0 & 0,00 & 2 & 1,04 \\
\hline $\begin{array}{c}\text { Condenação à Entrega de } \\
\text { Coisa Certa }\end{array}$ & 0 & 0,00 & 0 & 0,00 & 1 & 0,52 \\
\hline Embargos de Terceiros & 0 & 0,00 & 0 & 0,00 & 1 & 0,52 \\
\hline & 139 & 100,00 & 141 & 100,00 & 193 & 100,00 \\
\hline
\end{tabular}


Continuação da Tabela 22: Tipos de Ação no Juizado Especial de Pinheiros - Número e Percentual

\begin{tabular}{|c|c|c|c|c|c|c|c|c|}
\hline \multirow[t]{2}{*}{ Pinheiros } & \multicolumn{2}{|c|}{2003} & \multicolumn{2}{|c|}{2004} & \multicolumn{2}{|c|}{2005} & \multicolumn{2}{|c|}{ Totais } \\
\hline & $\mathrm{N}$ & $\%$ & $\mathrm{~N}$ & $\%$ & $\mathrm{~N}$ & $\%$ & $\mathrm{~N}$ & $\%$ \\
\hline $\begin{array}{l}\text { Condenação em } \\
\text { Dinheiro } \\
\end{array}$ & 42 & 20,10 & 42 & 22,46 & 43 & 24,16 & 279 & 26,65 \\
\hline $\begin{array}{c}\text { Condenação ao } \\
\text { Cumprimento de } \\
\text { Obrigação de Fazer ou } \\
\text { Não Fazer } \\
\end{array}$ & 47 & 22,49 & 28 & 14,97 & 32 & 17,98 & 181 & 17,29 \\
\hline $\begin{array}{c}\text { Reparação de Danos (em } \\
\text { geral) }\end{array}$ & 44 & 21,05 & 40 & 21,39 & 35 & 19,66 & 179 & 17,10 \\
\hline $\begin{array}{c}\text { Ressarcimento de Danos } \\
\text { Causados em Acidente } \\
\text { de Veículo }\end{array}$ & 28 & 13,40 & 21 & 11,23 & 22 & 12,36 & 156 & 14,90 \\
\hline $\begin{array}{l}\text { Desconstituição de } \\
\text { Contrato }\end{array}$ & 28 & 13,40 & 22 & 11,76 & 14 & 7,87 & 114 & 10,89 \\
\hline $\begin{array}{l}\text { Outros feitos não } \\
\text { especificados }\end{array}$ & 11 & 5,26 & 23 & 12,30 & 15 & 8,43 & 71 & 6,78 \\
\hline $\begin{array}{c}\text { Execução Título Extra- } \\
\text { Judicial }\end{array}$ & 6 & 2,87 & 7 & 3,74 & 11 & 6,18 & 50 & 4,78 \\
\hline $\begin{array}{c}\text { Declaração de Nulidade } \\
\text { de Contrato }\end{array}$ & 2 & 0,96 & 2 & 1,07 & 5 & 2,81 & 11 & 1,05 \\
\hline $\begin{array}{c}\text { Condenação à Entrega } \\
\text { de Coisa Certa }\end{array}$ & 1 & 0,48 & 0 & 0,00 & 0 & 0,00 & 2 & 0,19 \\
\hline Declaratória (em geral) & 0 & 0,00 & 1 & 0,53 & 0 & 0,00 & 1 & 0,10 \\
\hline Despejo & 0 & 0,00 & 1 & 0,53 & 0 & 0,00 & 1 & 0,10 \\
\hline Embargos de Terceiros & 0 & 0,00 & 0 & 0,00 & 0 & 0,00 & 1 & 0,10 \\
\hline Execução Título Judicial & 0 & 0,00 & 0 & 0,00 & 1 & 0,56 & 1 & 0,10 \\
\hline & 209 & 100,00 & 187 & 100,00 & 178 & 100,00 & 1047 & 100,00 \\
\hline
\end{tabular}

Fonte: Pesquisa de Campo, Erik Macedo Marques - 2006

No Juizado de Pinheiros, o tipo de ação mais encontrado foi “Condenação em Dinheiro”, com 26,7\%. No ano de 2001, alcança a sua maior participação percentual da série: 36,9\%. Em seguida temos “Condenação ao Cumprimento de Obrigação de Fazer ou Não Fazer”, com 17,3\%, e em 2003 apresenta a sua maior participação percentual, 22,5\%, sendo o tipo de ação mais freqüente para este ano. Com 17,1\%, “Reparação de Danos (em geral)” é o terceiro tipo de ação mais freqüente, participando em 2004 com 21,4\% das ações da amostra. "Ressarcimento de Danos Causados em Acidente de Veículos” é o quarto tipo de ação com maior expressão na amostra, representando 14,9\% da mesma, e participando com 24,5\% no ano de 2000. Do total da amostra para o Juizado de Pinheiros, 10,9\% foram do tipo de ação “Desconstituição de Contrato”, que em 2003 ocorre em $13,4 \%$ dos casos pesquisados nesse JEC. 
Observamos de um modo geral e com exceção do Juizado do CIC Leste no ano de 2005, que os tipos de ação mais freqüentes são as ações condenatórias. Sobre esse tipo de ação, Cintra et alli (2006, p. 54) afirmam que:

“Tanto no civil como no penal, o processo condenatório é o mais freqüente; no campo não-penal são condenatórios todos os processos que visem a obter a imposição ao réu de uma prestação de dar, fazer ou não-fazer.”

A seguir, a tabela 23 indica o número e o percentual de tipos de reclamado por Juizado. Observamos que o número total de reclamados não é o mesmo que o número total de feitos da amostra devido à presença de mais de um reclamado no pólo passivo da demanda (litisconsórcio passivo).

Tabela 23: Tipos de Reclamado nos Juizados Especiais - Número e Percentual

\begin{tabular}{c|cc|cc|cc|cc}
\hline \multicolumn{1}{c}{$\begin{array}{c}\text { Tipo de } \\
\text { Reclamado }\end{array}$} & \multicolumn{1}{c}{ CIC - Leste } & \multicolumn{2}{c}{ CIC - Oeste } & \multicolumn{2}{c}{ Pinheiros } & \multicolumn{2}{c}{ Total } \\
\hline \hline & $\mathrm{N}$ & $\%$ & $\mathrm{~N}$ & $\%$ & $\mathrm{~N}$ & $\%$ & Não & $\%$ \\
Micro Empresa & 9 & 1,30 & 10 & 1,70 & 16 & 1,31 & 35 & 1,40 \\
Pessoa Física & 192 & 27,79 & 379 & 64,35 & 467 & 38,37 & 1038 & 41,55 \\
Pessoa Jurídica & 490 & 70,91 & 200 & 33,96 & 734 & 60,31 & 1425 & 57,05 \\
Total & 691 & 100,00 & 589 & 100,00 & 1217 & 100,00 & 2498 & 100,00 \\
\hline \multicolumn{7}{c}{ Fonte: Pesquisa de Campo, Erik Macedo Marques - 2006 }
\end{tabular}




\section{Gráfico 05}

Percentual de Tipos de Réu por Juizado Especial

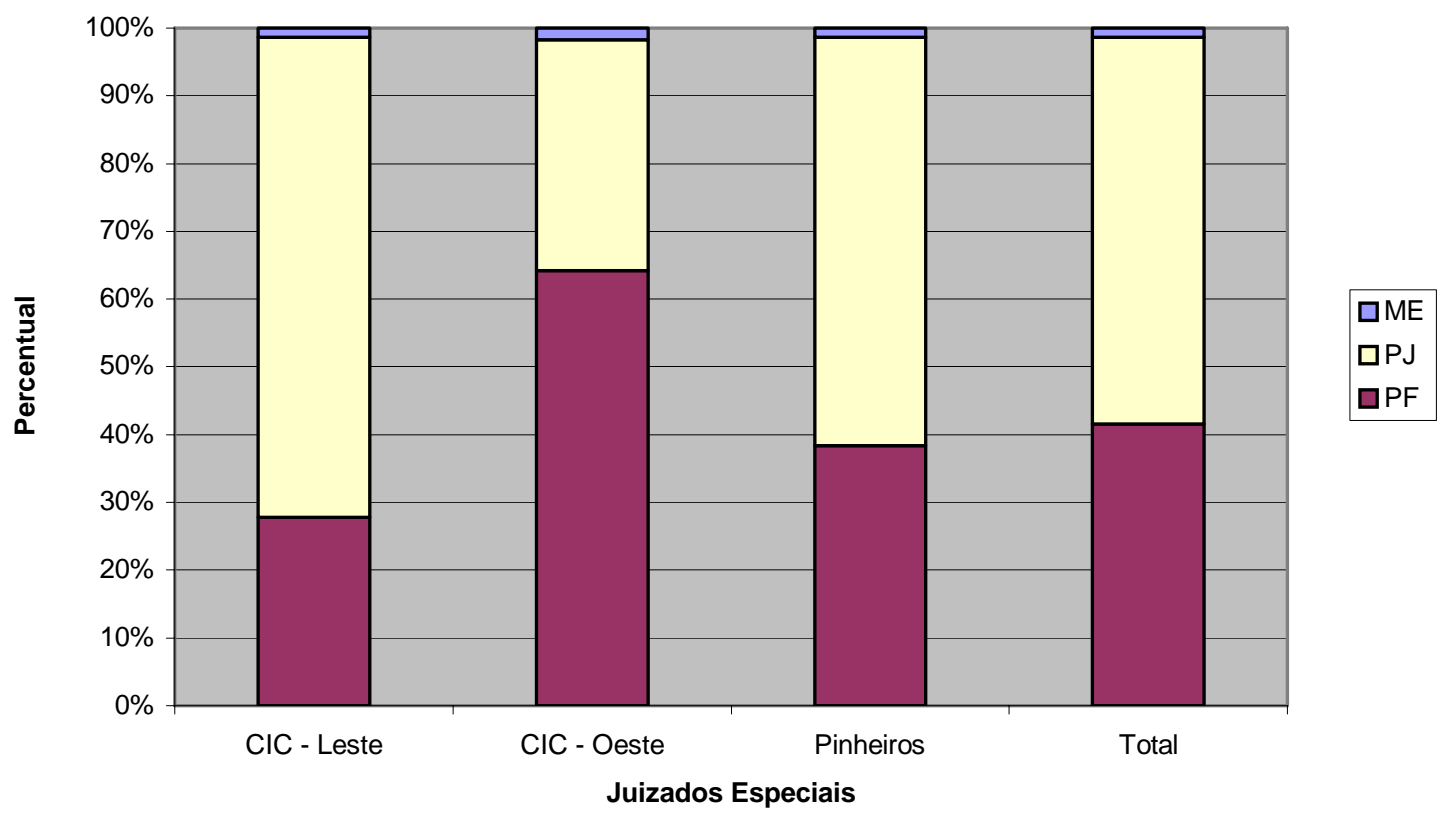

Fonte: Pesquisa de Campo, Erik Macedo Marques - 2006

No total dos três Juizados, a maioria das ações tem como reclamados Pessoas Jurídicas. Consideradas também as Micro-Empresas como Pessoas Jurídicas, 58,5\% dos tipos de reclamados encontrados são desse tipo. As Micro-Empresas participam com 1,4\% desse número. Já as Pessoas Físicas são 41,6\% do número de reclamados nos processos pesquisados.

No Juizado do CIC Leste, 72,1\% dos reclamados encontrados são do tipo Pessoa Jurídica, e deste total 1,3\% são Micro-Empresas. Pessoas Físicas participam em 27,8\% do número total de reclamados. No Juizado de Pinheiros, 61,6\% dos reclamados são Pessoas Jurídicas, sendo que deste total, 1,3\% são Micro-Empresas. As Pessoas Físicas participam com 38,4\% do número de reclamados por tipo neste Juizado.

Porém, no Juizado do CIC Oeste, 35,7\% dos reclamados são Pessoas Jurídicas e Micro-Empresas, e as Pessoas Físicas representam 64,4\% das ações da amostra. Portanto, de um modo geral, e concordando com as pesquisas anteriormente citadas, a hipótese de que as demandas dos Juizados Especiais têm como maior parte de seus reclamados Pessoas Jurídicas mantém-se. Mas, ao observarmos cada Juizado 
especificamente, não podemos aceitar esta hipótese, dada a maioria de Pessoas Físicas como reclamados no Juizado do CIC Oeste. Assim, a Hipótese 2 da nossa pesquisa não pode ser aceita em sua totalidade.

A seguir a tabela 24, que apresenta o número e o percentual de reclamados por tipo e por ano para o Juizado do CIC Leste.

Tabela 24: Tipo de Reclamado no Juizado Especial do CIC Leste - Número e Percentual

\begin{tabular}{c|cc|cc|cc|cc}
\hline \multicolumn{2}{c}{2003} & \multicolumn{2}{c}{2004} & \multicolumn{2}{c}{2005} & \multicolumn{2}{c}{ Total } \\
\hline CIC Leste & $\mathrm{N}$ & $\%$ & $\mathrm{~N}$ & $\%$ & $\mathrm{~N}$ & $\%$ & Não & $\%$ \\
Micro Empresa & 3 & 2,31 & 2 & 1,27 & 4 & 0,99 & 9 & 1,30 \\
Pessoa Física & 68 & 52,31 & 61 & 38,85 & 63 & 15,59 & 192 & 27,79 \\
Pessoa Jurídica & 59 & 45,38 & 94 & 59,87 & 337 & 83,42 & 490 & 70,91 \\
Total & 130 & 100,00 & 157 & 100,00 & 404 & 100,00 & 691 & 100,00 \\
\hline \hline
\end{tabular}

Fonte: Pesquisa de Campo, Erik Macedo Marques - 2006

Observa-se que, de 2003 a 2005 houve um acréscimo da participação percentual do tipo Pessoa Jurídica nos reclamados desse Juizado. De 45,3\% em 2003, em 2005 chega a 83,4\%. As Micro-Empresas e as Pessoas Físicas sofrem decréscimos na participação. As primeiras eram 2,3\% do número de reclamados em 2003, e em 2005 participam com apenas 1\%. Interessante notar que o tipo de reclamado Pessoa Física representa mais da metade dos reclamados em 2003, com 52,3\% de participação. Esta participação decresce e, no último ano da série, este tipo de reclamado é apenas 15,6\%.

Abaixo apresentamos a tabela 25, do número e percentual de reclamados por tipo e por ano para o Juizados do CIC Oeste.

Tabela 25: Tipo de Reclamado no Juizado Especial do CIC Oeste - Número e Percentual

\begin{tabular}{c|cc|cc|cc}
\hline \multicolumn{1}{c}{ CIC Oeste } & $\mathrm{N}$ & $\%$ & $\mathrm{~N}$ & $\%$ & $\mathrm{~N}$ & $\%$ \\
\hline \hline & 1 & 0,94 & 2 & 2,11 & 4 & 4,30 \\
Micro Empresa & 1 & 57,55 & 61 & 64,21 & 62 & 66,67 \\
Pessoa Física & 61 & 41,51 & 32 & 33,68 & 27 & 29,03 \\
Pessoa Jurídica & 44 & 100,00 & 95 & 100,00 & 93 & 100,00 \\
Total & 106 & Fonte: Pesquisa de Campo, Erik Macedo Marques - 2006
\end{tabular}


Continuação da Tabela 25: Tipo de Reclamado no Juizado Especial do CIC Oeste Número e Percentual

\begin{tabular}{c|cc|cc|cc|cc}
\hline \multicolumn{1}{c}{ CIC Oeste } & \multicolumn{2}{c}{2003} & \multicolumn{2}{c}{2004} & \multicolumn{2}{c}{2005} & \multicolumn{2}{c}{ Total } \\
\hline \hline & $\mathrm{N}$ & $\%$ & $\mathrm{~N}$ & $\%$ & $\mathrm{~N}$ & $\%$ & Não & $\%$ \\
Micro Empresa & 1 & 1,10 & 1 & 1,15 & 1 & 0,85 & 10 & 1,70 \\
Pessoa Física & 58 & 63,74 & 58 & 66,67 & 79 & 67,52 & 379 & 64,35 \\
Pessoa Jurídica & 32 & 35,16 & 28 & 32,18 & 37 & 31,62 & 200 & 33,96 \\
Total & 91 & 100,00 & 87 & 100,00 & 117 & 100,00 & 589 & 100,00 \\
\hline \hline
\end{tabular}

Fonte: Pesquisa de Campo, Erik Macedo Marques - 2006

Conforme já constatado, a maior parte dos reclamados deste Juizado é do tipo Pessoa Física (64,4\%). Durante toda a série, a maioria dos reclamados neste Juizado, por ano, foi também deste tipo. Há uma tendência de crescimento deste tipo de reclamado; apesar das oscilações, em 2000 o seu percentual de participação foi de 57,6\%, e no último ano da série este percentual é de 67,5\%.

O tipo de reclamado Pessoa Jurídica participa, no geral da amostra desse JEC, com 34\%, e apresenta leve tendência de decréscimo: inicia a série com 41,5\%, e termina com 31,6\%. Micro-Empresa, que neste Juizado foi o tipo de autor com maior participação em comparação aos outros, participa residualmente como reclamado, apenas $1,7 \%$.

Abaixo apresentamos a tabela 26, de número e percentual de participação de reclamado por tipo e por ano para o Juizado de Pinheiros.

Tabela 26: Tipo de Reclamado no Juizado Especial de Pinheiros - Número e Percentual

\begin{tabular}{c|cc|cc|cc}
\hline Pinheiros & \multicolumn{2}{c}{2000} & \multicolumn{2}{c}{2001} & \multicolumn{2}{c}{2002} \\
\hline \hline & $\mathrm{N}$ & $\%$ & $\mathrm{~N}$ & $\%$ & Não & $\%$ \\
Micro Empresa & 0 & 0,00 & 1 & 0,61 & 5 & 2,25 \\
Pessoa Física & 91 & 53,53 & 68 & 41,72 & 92 & 41,44 \\
Pessoa Jurídica & 79 & 46,47 & 94 & 57,67 & 125 & 56,31 \\
Total & 170 & 100,00 & 163 & 100,00 & 222 & 100,00 \\
\hline \hline
\end{tabular}

Fonte: Pesquisa de Campo, Erik Macedo Marques - 2006 
Continuação da Tabela 26: Tipo de Reclamado no Juizado Especial de Pinheiros Número e Percentual

\begin{tabular}{c|cc|cc|cc|cc}
\hline \multicolumn{2}{c}{ Pinheiros } & \multicolumn{2}{c}{2003} & \multicolumn{2}{c}{2004} & \multicolumn{2}{c}{2005} & \multicolumn{2}{c}{ Total } \\
\hline \hline & $\mathrm{N}$ & $\%$ & $\mathrm{~N}$ & $\%$ & $\mathrm{~N}$ & $\%$ & Não & $\%$ \\
Micro Empresa & 1 & 0,42 & 1 & 0,46 & 8 & 3,86 & 16 & 1,31 \\
Pessoa Física & 78 & 32,91 & 67 & 30,73 & 71 & 34,30 & 467 & 38,37 \\
Pessoa Jurídica & 158 & 66,67 & 150 & 68,81 & 128 & 61,84 & 734 & 60,31 \\
Total & 237 & 100,00 & 218 & 100,00 & 207 & 100,00 & 1217 & 100,00 \\
\hline \hline
\end{tabular}

Fonte: Pesquisa de Campo, Erik Macedo Marques - 2006

Neste Juizado, ocorreu no geral o esperado segundo a Hipótese 2: 60,3\% dos reclamados são Pessoa Jurídica. Porém, no ano de 2000, 53,5\% dos reclamados são do tipo Pessoa Física. Este último tipo de reclamado apresentou tendência de decréscimo, encerrando a série com o percentual de 38,37\%. O tipo Pessoa Jurídica cresceu de 46,5\% em 2000 para 61,84\% em 2005. As Micro-Empresas apresentam participação residual de 1,3\%.

Observa-se, a partir da análise de participação dos reclamados por ano, que a Hipótese 2 também não se confirma ao observarmos não só um Juizado específico, mas também a distribuição de um ano específico de determinado Juizado, pois, nos anos de 2003 para o Juizado do CIC Leste, e no ano de 2000 para o Juizado de Pinheiros, o tipo de reclamado mais freqüente foi Pessoa Física.

Apesar de constarmos que a Hipótese 2 não pode ser aceita para todo Juizado, nem para todo ano analisado, continuaremos a análise para verificar se dentre as Pessoas Jurídicas que participaram do pólo passivo das demandas da amostra há uma presença expressiva de concessionárias e prestadoras de serviço público.

Abaixo apresentamos a tabela 27, que relaciona o tipo de reclamado Pessoa Jurídica por agrupamento de atividade econômica para o Juizado do CIC Leste: 
Tabela 27: Tipo de Reclamado Pessoa Jurídica no Juizado Especial do CIC Leste Número e Percentual

\begin{tabular}{|c|c|c|c|c|c|c|c|c|}
\hline \multirow{2}{*}{ CIC Leste } & \multicolumn{2}{|c|}{2003} & \multicolumn{2}{|c|}{2004} & \multicolumn{2}{|c|}{2005} & \multicolumn{2}{|c|}{ Total } \\
\hline & $\mathrm{N}$ & $\%$ & $\mathrm{~N}$ & $\%$ & $\mathrm{~N}$ & $\%$ & $\mathrm{~N}$ & $\%$ \\
\hline Concessionária de Telefonia & 2 & 3,39 & 24 & 25,53 & 252 & 74,78 & 278 & 56,73 \\
\hline Comércio Varejista & 5 & 8,47 & 11 & 11,70 & 13 & 3,86 & 29 & 5,92 \\
\hline Concessionária de Energia & 5 & 8,47 & 7 & 7,45 & 14 & 4,15 & 26 & 5,31 \\
\hline Banco & 6 & 10,17 & 6 & 6,38 & 11 & 3,26 & 23 & 4,69 \\
\hline $\begin{array}{l}\text { Atividades de Educação e } \\
\text { Ensino }\end{array}$ & 1 & 1,69 & 10 & 10,64 & 10 & 2,97 & 21 & 4,29 \\
\hline $\begin{array}{l}\text { Prestação de Serviços em } \\
\text { Geral }\end{array}$ & 6 & 10,17 & 5 & 5,32 & 6 & 1,78 & 17 & 3,47 \\
\hline $\begin{array}{c}\text { Fabricação de } \\
\text { Eletrodomésticos e Aparelhos } \\
\text { Eletrônicos }\end{array}$ & 2 & 3,39 & 5 & 5,32 & 6 & 1,78 & 13 & 2,65 \\
\hline $\begin{array}{c}\text { Atividades de Intermediação } \\
\text { Financeira/Capitalização/ } \\
\text { Arrendamento Mercantil }\end{array}$ & 8 & 13,56 & 4 & 4,26 & 0 & 0,00 & 12 & 2,45 \\
\hline $\begin{array}{c}\text { Comércio, Reparação de } \\
\text { Veículos Automotores e Peças }\end{array}$ & 2 & 3,39 & 2 & 2,13 & 6 & 1,78 & 10 & 2,04 \\
\hline Atividades Imobiliárias & 3 & 5,08 & 3 & 3,19 & 2 & 0,59 & 8 & 1,63 \\
\hline Seguro & 5 & 8,47 & 1 & 1,06 & 1 & 0,30 & 7 & 1,43 \\
\hline Plano de Saúde & 2 & 3,39 & 1 & 1,06 & 2 & 0,59 & 5 & 1,02 \\
\hline Condomínio & 1 & 1,69 & 3 & 3,19 & 0 & 0,00 & 4 & 0,82 \\
\hline Construção Civil & 3 & 5,08 & 1 & 1,06 & 0 & 0,00 & 4 & 0,82 \\
\hline Operadora de Celular & 0 & 0,00 & 2 & 2,13 & 1 & 0,30 & 3 & 0,61 \\
\hline Transporte terrestre & 0 & 0,00 & 1 & 1,06 & 2 & 0,59 & 3 & 0,61 \\
\hline $\begin{array}{c}\text { Fabricação de Produtos em } \\
\text { Geral }\end{array}$ & 1 & 1,69 & 1 & 1,06 & 0 & 0,00 & 2 & 0,41 \\
\hline Cartão de Crédito & 0 & 0,00 & 1 & 1,06 & 0 & 0,00 & 1 & 0,20 \\
\hline Correios & 0 & 0,00 & 0 & 0,00 & 1 & 0,30 & 1 & 0,20 \\
\hline $\begin{array}{c}\text { Hospitais, Centros Médicos, } \\
\text { Centros de Diagnóstico } \\
\text { Clínico }\end{array}$ & 0 & 0,00 & 0 & 0,00 & 1 & 0,30 & 1 & 0,20 \\
\hline Sabesp & 0 & 0,00 & 1 & 1,06 & 0 & 0,00 & 1 & 0,20 \\
\hline Sem Especificação & 7 & 11,86 & 5 & 5,32 & 9 & 2,67 & 21 & 4,29 \\
\hline Total & 59 & 100,00 & 94 & 100,00 & 337 & 100,00 & 490 & 100,00 \\
\hline
\end{tabular}

Fonte: Pesquisa de Campo, Erik Macedo Marques - 2006

Para o Juizado do CIC Leste, a Hipótese 3, de que grande parte dos reclamados dos JEC's são prestadoras de serviço público, é aceita devido ao número geral de distribuição, desde a sua instalação até o final de 2005. Somente concessionárias de serviço de telefonia representam 56,7\% do total de reclamados pessoas jurídicas. Sobre o total de reclamados da amostra, o número dos que são prestadores de serviço público atinge 44,3\%, 
participação maior que a encontrada nos Juizados do Rio de Janeiro (32,5\% de reclamados prestadores de serviço público), conforme levantamento citado no capítulo anterior.

Porém, em uma análise mais detida, podemos observar que o ocorrido no ano de 2005 explica este alto índice de participação, com as ações contra a cobrança de assinaturas de serviço de telefonia, citadas quando tratamos do tipo de ação. Somente em 2005, 74,8\% dos reclamados pessoas jurídicas são concessionárias de telefonia. Neste ano, o percentual de prestadores de serviço público em face de todos os reclamados, sejam pessoas físicas ou jurídicas, alcança o valor de 66,1\%, ou seja, para 2005, a amostra aponta que mais da metade dos reclamados de todos os processos foram prestadores de serviço público, e $62,4 \%$ de todos os reclamados contra os quais foram interpostas ações neste ano são concessionárias de telefonia.

Nos outros anos da série as concessionárias de telefonia são 3,4\% das pessoas jurídicas em 2003 e em 2004 participam como 25,5\% dos reclamados pessoas jurídicas.

O serviço de energia também aparece com expressivos percentuais neste Juizado, representando uma participação de 5,3\% frente às pessoas jurídicas rés. Em 2003 representa 8,5\% e, em 2004 cai para 7,5\%, terminando a série com 4,2\%.

Sabesp e Correios, duas empresas públicas, participam residualmente, com apenas 1 caso cada.

A participação de atividades de intermediação financeira ${ }^{27}$ neste Juizado é de 9,8\% das pessoas jurídicas, com os bancos representando 4,7\% do total de pessoas jurídicas rés.

Cabe destacar também a grande participação do setor de comércio varejista (lojas de eletrodomésticos, móveis, roupas etc.) neste Juizado. Ao todo, essas lojas e empresas representam 5,9\% dos reclamados pessoas jurídicas.

Abaixo apresentamos a tabela 28, com o número e o percentual de participação por tipo de reclamado pessoa jurídica para o Juizado do Fórum de Pinheiros. 
Tabela 28: Tipo de Reclamado Pessoa Jurídica no Juizado Especial de Pinheiros Número e Percentual

\begin{tabular}{|c|c|c|c|c|c|c|c|c|}
\hline \multirow{2}{*}{ Pinheiros } & \multicolumn{2}{|c|}{2000} & \multicolumn{2}{|c|}{2001} & \multicolumn{2}{|c|}{2002} & \multicolumn{2}{|c|}{2003} \\
\hline & $\mathrm{N}$ & $\%$ & $\mathrm{~N}$ & $\%$ & $\mathrm{~N}$ & $\%$ & $\mathrm{~N}$ & $\%$ \\
\hline $\begin{array}{c}\text { Prestação de Serviços em } \\
\text { Geral }\end{array}$ & 8 & 10,13 & 18 & 19,15 & 22 & 17,60 & 24 & 15,19 \\
\hline Comércio Varejista & 11 & 13,92 & 17 & 18,09 & 13 & 10,40 & 16 & 10,13 \\
\hline Banco & 10 & 12,66 & 4 & 4,26 & 9 & 7,20 & 16 & 10,13 \\
\hline Concessionária de Telefonia & 5 & 6,33 & 6 & 6,38 & 9 & 7,20 & 6 & 3,80 \\
\hline $\begin{array}{c}\text { Comércio, Reparação de } \\
\text { Veículos Automotores e Peças }\end{array}$ & 6 & 7,59 & 7 & 7,45 & 9 & 7,20 & 4 & 2,53 \\
\hline Operadora de Celular & 1 & 1,27 & 2 & 2,13 & 0 & 0,00 & 11 & 6,96 \\
\hline $\begin{array}{l}\text { Atividades de Educação e } \\
\text { Ensino }\end{array}$ & 5 & 6,33 & 4 & 4,26 & 8 & 6,40 & 4 & 2,53 \\
\hline $\begin{array}{c}\text { Fabricação de } \\
\text { Eletrodomésticos e Aparelhos } \\
\text { Eletrônicos }\end{array}$ & 4 & 5,06 & 0 & 0,00 & 6 & 4,80 & 8 & 5,06 \\
\hline Atividades Imobiliárias & 5 & 6,33 & 2 & 2,13 & 4 & 3,20 & 6 & 3,80 \\
\hline $\begin{array}{c}\text { Atividades de Intermediação } \\
\text { Financeira/Capitalização/ } \\
\text { Arrendamento Mercantil }\end{array}$ & 1 & 1,27 & 2 & 2,13 & 6 & 4,80 & 6 & 3,80 \\
\hline Seguro & 1 & 1,27 & 1 & 1,06 & 3 & 2,40 & 5 & 3,16 \\
\hline Transporte terrestre & 0 & 0,00 & 5 & 5,32 & 5 & 4,00 & 6 & 3,80 \\
\hline Plano de Saúde & 1 & 1,27 & 3 & 3,19 & 2 & 1,60 & 6 & 3,80 \\
\hline Concessionária de Energia & 2 & 2,53 & 0 & 0,00 & 3 & 2,40 & 4 & 2,53 \\
\hline Condomínio & 2 & 2,53 & 0 & 0,00 & 6 & 4,80 & 3 & 1,90 \\
\hline Cartão de Crédito & 2 & 2,53 & 1 & 1,06 & 4 & 3,20 & 0 & 0,00 \\
\hline $\begin{array}{l}\text { Hospitais, Centros Médicos, } \\
\text { Centros de Diagnóstico Clínico }\end{array}$ & 2 & 2,53 & 1 & 1,06 & 1 & 0,80 & 4 & 2,53 \\
\hline Construção Civil & 1 & 1,27 & 4 & 4,26 & 0 & 0,00 & 4 & 2,53 \\
\hline Sabesp & 2 & 2,53 & 2 & 2,13 & 1 & 0,80 & 2 & 1,27 \\
\hline Supermercado & 2 & 2,53 & 0 & 0,00 & 0 & 0,00 & 2 & 1,27 \\
\hline $\begin{array}{l}\text { Atividades de Organizações } \\
\text { Sindicais }\end{array}$ & 0 & 0,00 & 0 & 0,00 & 0 & 0,00 & 0 & 0,00 \\
\hline $\begin{array}{l}\text { Comércio a Varejo de } \\
\text { Combustíveis }\end{array}$ & 1 & 1,27 & 0 & 0,00 & 0 & 0,00 & 0 & 0,00 \\
\hline $\begin{array}{c}\text { Fabricação de Produtos em } \\
\text { Geral }\end{array}$ & 0 & 0,00 & 1 & 1,06 & 0 & 0,00 & 1 & 0,63 \\
\hline Cetesb & 0 & 0,00 & 0 & 0,00 & 1 & 0,80 & 0 & 0,00 \\
\hline Correios & 0 & 0,00 & 0 & 0,00 & 0 & 0,00 & 0 & 0,00 \\
\hline Fundação SEADE & 0 & 0,00 & 0 & 0,00 & 1 & 0,80 & 0 & 0,00 \\
\hline Infraero & 0 & 0,00 & 0 & 0,00 & 0 & 0,00 & 1 & 0,63 \\
\hline Sem Especificação & 7 & 8,86 & 14 & 14,89 & 12 & 9,60 & 19 & 12,03 \\
\hline Total & 79 & 100,00 & 94 & 100,00 & 125 & 100,00 & 158 & 100,00 \\
\hline
\end{tabular}

Fonte: Pesquisa de Campo, Erik Macedo Marques - 2006

\footnotetext{
${ }^{27}$ Considerou-se, para fins do conceito de intermediação financeira, as atividades de banco, Atividades de Intermediação Financeira - Capitalização - Arrendamento Mercantil; Seguro, Plano Saúde e Cartão de Crédito,
} 
Continuação da Tabela 28: Tipo de Reclamado Pessoa Jurídica no Juizado Especial de Pinheiros - Número e Percentual

\begin{tabular}{|c|c|c|c|c|c|c|}
\hline \multirow{2}{*}{ Pinheiros } & \multicolumn{2}{|c|}{2004} & \multicolumn{2}{|c|}{2005} & \multicolumn{2}{|c|}{ Total } \\
\hline & $\mathrm{N}$ & $\%$ & $\mathrm{~N}$ & $\%$ & $\mathrm{~N}$ & $\%$ \\
\hline Prestação de Serviços em Geral & 20 & 13,33 & 28 & 21,88 & 120 & 16,35 \\
\hline Comércio Varejista & 15 & 10,00 & 16 & 12,50 & 88 & 11,99 \\
\hline Banco & 14 & 9,33 & 11 & 8,59 & 64 & 8,72 \\
\hline Concessionária de Telefonia & 14 & 9,33 & 6 & 4,69 & 46 & 6,27 \\
\hline $\begin{array}{c}\text { Comércio, Reparação de Veículos } \\
\text { Automotores e Peças }\end{array}$ & 6 & 4,00 & 4 & 3,13 & 36 & 4,90 \\
\hline Operadora de Celular & 14 & 9,33 & 8 & 6,25 & 36 & 4,90 \\
\hline Atividades de Educação e Ensino & 7 & 4,67 & 4 & 3,13 & 32 & 4,36 \\
\hline $\begin{array}{l}\text { Fabricação de Eletrodomésticos e Aparelhos } \\
\text { Eletrônicos }\end{array}$ & 7 & 4,67 & 5 & 3,91 & 30 & 4,09 \\
\hline Atividades Imobiliárias & 6 & 4,00 & 5 & 3,91 & 28 & 3,81 \\
\hline $\begin{array}{c}\text { Atividades de Intermediação } \\
\text { Financeira/Capitalização/ Arrendamento } \\
\text { Mercantil }\end{array}$ & 7 & 4,67 & 3 & 2,34 & 25 & 3,41 \\
\hline Seguro & 7 & 4,67 & 8 & 6,25 & 25 & 3,41 \\
\hline Transporte terrestre & 5 & 3,33 & 4 & 3,13 & 25 & 3,41 \\
\hline Plano de Saúde & 4 & 2,67 & 2 & 1,56 & 18 & 2,45 \\
\hline Concessionária de Energia & 4 & 2,67 & 4 & 3,13 & 17 & 2,32 \\
\hline Condomínio & 2 & 1,33 & 4 & 3,13 & 17 & 2,32 \\
\hline Cartão de Crédito & 6 & 4,00 & 1 & 0,78 & 14 & 1,91 \\
\hline $\begin{array}{c}\text { Hospitais, Centros Médicos, Centros de } \\
\text { Diagnóstico Clínico }\end{array}$ & 0 & 0,00 & 4 & 3,13 & 12 & 1,63 \\
\hline Construção Civil & 0 & 0,00 & 1 & 0,78 & 10 & 1,36 \\
\hline Sabesp & 0 & 0,00 & 2 & 1,56 & 9 & 1,23 \\
\hline Supermercado & 2 & 1,33 & & 0,00 & 6 & 0,82 \\
\hline Atividades de Organizações Sindicais & 1 & 0,67 & 3 & 2,34 & 4 & 0,54 \\
\hline Comércio a Varejo de Combustíveis & 0 & 0,00 & 2 & 1,56 & 3 & 0,41 \\
\hline Fabricação de Produtos em Geral & 0 & 0,00 & & 0,00 & 2 & 0,27 \\
\hline Cetesb & 0 & 0,00 & 0 & 0,00 & 1 & 0,14 \\
\hline Correios & 0 & 0,00 & 1 & 0,78 & 1 & 0,14 \\
\hline Fundação SEADE & 0 & 0,00 & 0 & 0,00 & 1 & 0,14 \\
\hline Infraero & 0 & 0,00 & 0 & 0,00 & 1 & 0,14 \\
\hline Sem Especificação & 9 & 6,00 & 2 & 1,56 & 63 & 8,58 \\
\hline Total & 150 & 100,00 & 128 & 100,00 & 734 & 100,00 \\
\hline
\end{tabular}

Fonte: Pesquisa de Campo, Erik Macedo Marques - 2006

No Juizado de Pinheiros, a participação de todos os prestadores de serviço público no pólo passivo da demanda é de 10,4\% das pessoas jurídicas. De todos os reclamados, considerando também Pessoas Físicas, o percentual de prestadores de serviço 
público é de 6,2\%. Uma participação relativamente pequena em relação ao Juizado do CIC Leste.

Em 2002 e 2004 a participação de empresas públicas e concessionárias alcança o seu maior valor: $12 \%$ das pessoas jurídicas, e, respectivamente, 6,7\% e 8,3\% para todos os reclamados. O serviço público que apresenta maior participação é o de telefonia fixa, com 46 casos na amostra de todos os anos, representando 6,3\% de todos os reclamados pessoas jurídicas. De um modo geral, os dados não demonstram nenhuma tendência de crescimento da demanda sobre serviços públicos como questões desse Juizado.

A participação de atividades de intermediação financeira representa um percentual maior dos reclamados, com $20 \%$, sendo os bancos responsáveis por 8,7\% de todos os reclamados pessoas jurídicas.

Cabe destacar também, como representantes de pessoas jurídicas da área privada, a expressiva presença de empresas prestadoras de serviço, tais como conserto de eletrodomésticos e móveis, assistência de informática, estacionamentos, academias de ginástica, TV a cabo etc. Este tipo de reclamado representa 16,4\% das pessoas jurídicas desse Juizado. As lojas e empresas do comércio varejista também têm relevante participação: 12\% dos reclamados pessoas jurídicas são desse ramo de atividade.

A seguir apresentamos a tabela 29, com os números e percentuais dos reclamados por tipo de pessoa jurídica para o Juizado do CIC Oeste: 
Tabela 29: Tipo de Reclamado Pessoa Jurídica no Juizado Especial do CIC Oeste Número e Percentual

\begin{tabular}{|c|c|c|c|c|c|c|c|c|}
\hline \multirow[t]{2}{*}{ CIC Oeste } & \multicolumn{2}{|c|}{2000} & \multicolumn{2}{|c|}{2001} & \multicolumn{2}{|c|}{2002} & \multicolumn{2}{|c|}{2003} \\
\hline & $\mathrm{N}$ & $\%$ & Não & $\%$ & $\mathrm{~N}$ & $\%$ & $\mathrm{~N}$ & $\%$ \\
\hline Comércio Varejista & 10 & 22,73 & 12 & 37,50 & 6 & 22,22 & 4 & 12,50 \\
\hline $\begin{array}{l}\text { Prestação de Serviços em } \\
\text { Geral }\end{array}$ & 8 & 18,18 & 4 & 12,50 & 7 & 25,93 & 0 & 0,00 \\
\hline $\begin{array}{c}\text { Comércio, Reparação de } \\
\text { Veículos Automotores e Peças }\end{array}$ & 6 & 13,64 & 5 & 15,63 & 1 & 3,70 & 4 & 12,50 \\
\hline $\begin{array}{c}\text { Atividades de Intermediação } \\
\text { Financeira/Capitalização/ } \\
\text { Arrendamento Mercantil }\end{array}$ & 3 & 6,82 & 3 & 9,38 & 2 & 7,41 & 2 & 6,25 \\
\hline Banco & 0 & 0,00 & 2 & 6,25 & 0 & 0,00 & 5 & 15,63 \\
\hline $\begin{array}{l}\text { Atividades de Educação e } \\
\text { Ensino }\end{array}$ & 3 & 6,82 & 0 & 0,00 & 0 & 0,00 & 0 & 0,00 \\
\hline Atividades Imobiliárias & 2 & 4,55 & 1 & 3,13 & 1 & 3,70 & 3 & 9,38 \\
\hline Sem Especificação & 4 & 9,09 & 0 & 0,00 & 0 & 0,00 & 2 & 6,25 \\
\hline Concessionária de Energia & 0 & 0,00 & 0 & 0,00 & 1 & 3,70 & 3 & 9,38 \\
\hline $\begin{array}{l}\text { Atividades de Organizações } \\
\text { Sindicais }\end{array}$ & 0 & 0,00 & 1 & 3,13 & 3 & 11,11 & 0 & 0,00 \\
\hline Concessionária de Telefonia & 2 & 4,55 & 0 & 0,00 & 0 & 0,00 & 1 & 3,13 \\
\hline Operadora de Celular & 0 & 0,00 & 1 & 3,13 & 1 & 3,70 & 0 & 0,00 \\
\hline Sabesp & 0 & 0,00 & 0 & 0,00 & 1 & 3,70 & 1 & 3,13 \\
\hline Supermercado & 0 & 0,00 & 1 & 3,13 & 1 & 3,70 & 1 & 3,13 \\
\hline Cartão de Crédito & 2 & 4,55 & 0 & 0,00 & 0 & 0,00 & 1 & 3,13 \\
\hline $\begin{array}{l}\text { Comércio a Varejo de } \\
\text { Combustíveis }\end{array}$ & 1 & 2,27 & 0 & 0,00 & 0 & 0,00 & 1 & 3,13 \\
\hline Condomínio & 0 & 0,00 & 0 & 0,00 & 1 & 3,70 & 1 & 3,13 \\
\hline Construção Civil & 0 & 0,00 & 0 & 0,00 & 1 & 3,70 & 2 & 6,25 \\
\hline $\begin{array}{c}\text { Fabricação de } \\
\text { Eletrodomésticos e Aparelhos } \\
\text { Eletrônicos }\end{array}$ & 1 & 2,27 & 1 & 3,13 & 0 & 0,00 & 0 & 0,00 \\
\hline $\begin{array}{c}\text { Fabricação de Produtos em } \\
\text { Geral }\end{array}$ & 1 & 2,27 & 0 & 0,00 & 0 & 0,00 & 1 & 3,13 \\
\hline Plano de Saúde & 1 & 2,27 & 0 & 0,00 & 0 & 0,00 & 0 & 0,00 \\
\hline Seguro & 0 & 0,00 & 0 & 0,00 & 1 & 3,70 & 0 & 0,00 \\
\hline Transporte terrestre & 0 & 0,00 & 1 & 3,13 & 0 & 0,00 & 0 & 0,00 \\
\hline Total & 44 & 100,00 & 32 & 100,00 & 27 & 100,00 & 32 & 100,00 \\
\hline
\end{tabular}

Fonte: Pesquisa de Campo, Erik Macedo Marques - 2006 
Continuação da Tabela 29: Tipo de Reclamado Pessoa Jurídica no Juizado Especial do CIC Oeste - Número e Percentual

\begin{tabular}{|c|c|c|c|c|c|c|}
\hline CIC Oeste & 2004 & & 2005 & & Total & \\
\hline & $\mathrm{N}$ & $\%$ & $\mathrm{~N}$ & $\%$ & $\mathrm{~N}$ & $\%$ \\
\hline Comércio Varejista & 4 & 14,29 & 3 & 8,11 & 39 & 19,50 \\
\hline Prestação de Serviços em Geral & 4 & 14,29 & 8 & 21,62 & 31 & 15,50 \\
\hline $\begin{array}{c}\text { Comércio, Reparação de Veículos } \\
\text { Automotores e Peças }\end{array}$ & 1 & 3,57 & 7 & 18,92 & 24 & 12,00 \\
\hline $\begin{array}{c}\text { Atividades de Intermediação } \\
\text { Financeira/Capitalização/ Arrendamento } \\
\text { Mercantil } \\
\end{array}$ & 1 & 3,57 & 2 & 5,41 & 13 & 6,50 \\
\hline Banco & 4 & 14,29 & 2 & 5,41 & 13 & 6,50 \\
\hline Atividades de Educação e Ensino & 3 & 10,71 & 3 & 8,11 & 9 & 4,50 \\
\hline Atividades Imobiliárias & 0 & 0,00 & 1 & 2,70 & 8 & 4,00 \\
\hline Sem Especificação & 0 & 0,00 & 1 & 2,70 & 7 & 3,50 \\
\hline Concessionária de Energia & 1 & 3,57 & 1 & 2,70 & 6 & 3,00 \\
\hline Atividades de Organizações Sindicais & 1 & 3,57 & 0 & 0,00 & 5 & 2,50 \\
\hline Concessionária de Telefonia & 2 & 7,14 & 0 & 0,00 & 5 & 2,50 \\
\hline Operadora de Celular & 2 & 7,14 & 1 & 2,70 & 5 & 2,50 \\
\hline Sabesp & 2 & 7,14 & 1 & 2,70 & 5 & 2,50 \\
\hline Supermercado & 0 & 0,00 & 2 & 5,41 & 5 & 2,50 \\
\hline Cartão de Crédito & 1 & 3,57 & 0 & 0,00 & 4 & 2,00 \\
\hline Comércio a Varejo de Combustíveis & 0 & 0,00 & 1 & 2,70 & 3 & 1,50 \\
\hline Condomínio & 1 & 3,57 & 0 & 0,00 & 3 & 1,50 \\
\hline Construção Civil & 0 & 0,00 & 0 & 0,00 & 3 & 1,50 \\
\hline $\begin{array}{l}\text { Fabricação de Eletrodomésticos e Aparelhos } \\
\text { Eletrônicos }\end{array}$ & 0 & 0,00 & 1 & 2,70 & 3 & 1,50 \\
\hline Fabricação de Produtos em Geral & 0 & 0,00 & 1 & 2,70 & 3 & 1,50 \\
\hline Plano de Saúde & 0 & 0,00 & 1 & 2,70 & 2 & 1,00 \\
\hline Seguro & 0 & 0,00 & 1 & 2,70 & 2 & 1,00 \\
\hline Transporte terrestre & 1 & 3,57 & 0 & 0,00 & 2 & 1,00 \\
\hline Total & 28 & 100,00 & 37 & 100,00 & 200 & 100,00 \\
\hline
\end{tabular}

Fonte: Pesquisa de Campo, Erik Macedo Marques - 2006

No Juizado do CIC Oeste, a participação percentual dos prestadores de serviço público é de $8 \%$ sobre o total de reclamados pessoas jurídicas, a menor participação percentual de todos os Juizados pesquisados. Considerando que pessoas jurídicas têm um percentual menor de reclamados do que as pessoas físicas neste Juizado, no geral, os prestadores de serviço público representam apenas 2,7\% de todos os reclamados, com apenas 76 casos em 1.217 da amostra. No ano de 2004 encontramos a maior participação deste tipo, entretanto, a sua presença é de apenas 5,7\%. Assim, devido a estas constatações, a Hipótese $\underline{3}$, de que os prestadores de serviço público estão significativamente presentes como reclamados dos Juizados Especiais, não pode ser aceita por completo. 
O prestador de serviço público com maior freqüência neste JEC são as concessionárias de energia elétrica, porém são apenas 6 casos na amostra, 3\% dos reclamados pessoas jurídicas. As concessionárias de telefonia aparecem em apenas 5 casos, e representam 2,5\% das pessoas jurídicas do pólo passivo das demandas.

As atividades de intermediação financeira superam a participação dos serviços públicos. Representam 17\% dos reclamados pessoa jurídica, com os bancos e as Atividades de Intermediação Financeira/Capitalização/Arrendamento Mercantil representando $6 \%$ cada.

As demandas contra empresas do comércio varejista apresentam o maior percentual de pessoas jurídicas, 19,5\%. As empresas de prestação de serviço aparecem como o segundo tipo mais freqüente, representando 15,5\%. Em seguida temos as lojas e empresas de comércio e reparação de veículos automotores e peças, que percentualmente participam como $12 \%$ dos reclamados pessoas jurídicas.

Da análise dos dados encontrados nesses três Juizados para tipo de autor, tipo de reclamado e tipo de ação, a principal conclusão que podemos elaborar é a variabilidade dos perfis dos Juizados Especiais Cíveis. Os tipos de autores encontrados confirmam a hipótese da grande presença de pessoas físicas nos Juizados Especiais, porém, a presença dos condomínios como autores nestes locais indica que os critérios para o ingresso não são únicos, variando conforme o entendimento do Juiz Diretor do JEC.

Os tipos de ações encontrados também indicam perfis diversos de Juizados. Enquanto que o CIC Leste sofreu um acréscimo acima do normal em suas ações por conta de feitos contra a assinatura de linha telefônica, o mesmo não ocorreu nos outros dois JEC's, e podemos observar inclusive que no outro CIC, o Oeste, a expressividade deste tipo de demanda é praticamente nula.

O resultado da pesquisa para a presença de pessoas jurídicas como reclamados nos processos não nos deixa acatar a hipótese de sua expressiva representatividade. Os Juizados do CIC Leste e Pinheiros apresentam grande participação deste tipo de reclamado, porém, se considerarmos a demanda do CIC Oeste, não podemos afirmar que todos os Juizados apresentem esse perfil, mesmo que estejam na mesma cidade e participem do mesmo projeto de facilitação do acesso à justiça. E, mesmo que a participação percentual para prestadoras de serviços públicos nos três Juizados somados represente 15,9\% do total dos reclamados da amostra, não podemos generalizar este dado, pois em nenhum dos outros dois Juizados ocorreu o boom de ações contra a telefonia fixa que houve no CIC Leste. 


\section{Considerações Conclusivas}

Os Juizados Especiais Cíveis, reconhecidos com a Lei 9.099/95, foram concebidos a partir da percepção da falta da garantia do acesso à justiça para a população. A constatação e a imagem de um Judiciário lento e ineficaz, bem como os altos custos impostos para os litigantes, fatores da litigiosidade contida, somados ao debate das questões e experiências de acesso à justiça e aos altos deficits da administração pública, implicaram em um movimento de reforma dos procedimentos que perdura duas décadas. Da ação de tribunais arbitrais, à condução do processo pelo Executivo nacional, com a criação dos Juizados de Pequenas Causas aos Juizados Especiais, a reforma judicial conviveu (e convive) tanto com o reconhecimento de novos direitos quanto com a reforma da própria máquina administrativa brasileira.

Observamos que, apesar do atraso apontado tanto no reconhecimento quanto na garantia dos direitos de primeira geração, há um esforço, por vezes desconexo e superposto, de reforma de diversas áreas visando, em um primeiro momento, sanar uma administração pública falha e custosa, e, em um segundo ponto, tornar esta mesma administração ágil e eficaz para a melhor prestação dos serviços que apoiam a sua existência.

A evolução do reconhecimento e garantias de direitos no Brasil, bem como as ações administrativas para assegurá-los, não seguem a linha temporal dos países centrais, e, muitas vezes, são alvo de retrocessos. As falhas do sistema dos juizados tornam-se aparentes quando próprios colaboradores do projeto de lei que os criou reconhecem, como Watanabe (in Grinover 2001), que há falta de recursos e de reconhecimento pela própria administração dos tribunais da importância desta iniciativa. Porém, observa-se que o crescimento da demanda dos juizados os legitimam como um locus de reconhecimento público para a solução de litígios de menor complexidade. Não podemos inferir diretamente que esta demanda advém da população mais carente, mas projetos como os CIC’s indicam que há, por tímido que ainda possa ser, iniciativas para se alcançar áreas pobres e carentes com a prestação de serviços públicos.

Esta expansão do sistema dos juizados, utilizando-se também de parcerias e instrumentos pré-processuais como o "Expressinho", denotam o grande potencial deste novo modelo de resolução de conflitos em adaptar-se às necessidades de seus usuários. Podemos afirmar que, de todas as iniciativas, esta reforma decididamente trouxe nova luz 
sobre as exigências rígidas e formais do sistema jurídico para poder atuar. A informalidade e a oralidade, a busca constante pela conciliação entre as partes, indicam não apenas uma mudança dos procedimentos, mas uma mudança das próprias concepções sobre o que é a aplicação do direito. A legitimidade da decisão não é mais tão atrelada ao procedimento rígido e formal, mas sim à possibilidade do reconhecimento do Judiciário e da resolução eficaz do conflito, em tempo hábil e com o mínimo de custo para as partes.

A coexistência das mudanças como expansão de direitos do consumidor com reformas profundas na administração pública, no que tange principalmente à prestação de serviços públicos, em conjunto com as constatações empíricas apontadas, indicavam para a grande presença de conflitos contra concessionárias nos Juizados Especiais. Porém não foi o encontrado.

Podemos concluir que há um aumento da demanda desses Juizados, indicando o seu maior reconhecimento por parte da população. Mas, mesmo que dados agregados apontem para uma maior presença de demandas no Judiciário em regiões de maior desenvolvimento sócio-econômico, casos como o CIC Leste fogem a esta regra: em uma região carente encontramos um número bem maior de feitos comparado à regiões de melhor situação sócio-econômica, e, neste juizado, houve um maior impacto das ações contra assinatura de telefonia do que nos outros.

Analisando os autores encontrados na amostra, verifica-se que a hipótese geral de que são pessoas físicas na quase totalidade dos feitos confirma-se, porém a existência de condomínios como autores impõe uma nova questão: a heterogeneidade do sistema. Apesar das iniciativas principais para a implementação desse sistema de juizados, bem como as ações mais relevantes no que tange à reforma do judiciário, serem em grande parte conduzidas pela administração federal, há uma variação de entendimentos que produzem nos Estados diferentes tipos de procedimentos. Este fato é constatado na aceitação ou não de condomínios como autores a depender da Unidade Federativa em questão.

Diante dos dados da amostra não podemos afirmar que houve um grande impacto na aceitação das micro-empresas como autores nos JEC's, nem tampouco indicar que em regiões de maior desenvolvimento sócio-econômico elas atuam com maior ou menor freqüência.

A análise dos tipos de ações dos juizados pesquisados indica uma grande presença de ações de natureza condenatória, a mais freqüente na justiça comum também. Mas, situações como a ocorrida no CIC Leste, de um boom de ações contra 
assinatura telefônica, indica que há uma variação sazonal de demandas, não nos deixando inferir que esta conclusão inicial seja uma constante nos juizados considerados isoladamente.

A presença de pessoas jurídicas como reclamados nos feitos dos JEC’s também não pode ser tomada como uma verdade do sistema. Variações anuais no mesmo Juizado, bem como perfis diferentes de um Juizado indicam o contrário desta afirmativa.

Os prestadores de serviços públicos, objetivo inicial da pesquisa, revelaram uma presença variável nos diversos juizados, e até mesmo inexpressiva no CIC Oeste. Questões isoladas como telefonia e energia elétrica também não podem ser indicadas como presentes em maior ou menor grau nos Juizados. Não houve também uma variação do tipo de reclamado dependente da situação sócio-econômica.

A partir desta pesquisa, podemos afirmar que os Juizados Especiais Cíveis não apresentam uma uniformidade do perfil de sua demanda. E, mesmo que os dados agregados indiquem uma determinada tendência, esta não pode ser assumida para cada um dos Juizados individualmente. O mesmo vale para generalizações a partir de estudos específicos de um Juizado, pois o perfil de sua demanda não pode ser assumido como presente também nos demais. O número de demandas relativas à prestação de serviço público, principalmente contra prestadores de serviço de telefonia fixa, é constatado somente no Juizado do CIC Leste como expressivo, e em uma quantidade bem maior do que a encontrada nos JEC's de Pinheiros e CIC Oeste.

A constatação maior a ser feita é a variabilidade dos perfis de juizados. Esta variabilidade foi observada tanto no que tange a regras administrativas, como o caso dos condomínios, quanto ao tipo de demanda de cada juizado. Talvez esse fato seja um reflexo da grande mudança provocada no entendimento sobre prestação jurisdicional, ou talvez pela baixa institucionalização do sistema. A flexibilização dos procedimentos trazida com a reforma judicial provocou diferentes impactos, tornando a Justiça desses centros mais sensível às necessidades regionais, ou até mesmo às sazonalidades dos tipos de demanda, como o caso da assinatura telefônica. Os Juizados aparentam moldar-se ao tipo de região em que se localizam, porém indicadores sócio-econômicos não se apresentam como variáveis independentes a condicionar o tipo de perfil de demanda encontrada. Em resumo, afirmações genéricas como os Juizados sendo "balcão de reclamação" sobre a prestação dos serviços públicos não podem ser aceitas diante da grande riqueza de variações que este sistema apresenta. 


\section{Referências Bibliográficas}

Arantes, Rogério Bastos, Judiciário e Política no Brasil, São Paulo, Idesp/Fapesp/Educ, 1997.

ARaúJo, José Renato de CAMPos, O Projeto CIC (Centro de Integração da Cidadania), in Maria Tereza SADEK (org.), Acesso à Justiça, São Paulo, Konrad Adenauer, 2001, 205 a 218.

Bressan, Sílvio, Reforma Administrativa, in LAmounier, Bolívar e Figueiredo, Rubens, A Era FHC: Um Balanço, São Paulo, Cultura, 2002, pp.369 - 394.

Burgos, Marcelo e Vianna, Luiz Werneck, Revolução Processual do Direito $e$ Democracia Progressiva, in Vianna, LuIz WERnECK (org.), A Democracia e os Três Poderes no Brasil, Belo Horizonte/Rio de Janeiro, UFMG/IUPERJ/FAPERJ, 2003, pp. 337 a 492.

Capelletti, Mauro e Garth, Bryant, Acesso à Justiça, Porto Alegre, Sergio Antonio Fabris, 2002.

Capelletti, Mauro, Juízes Legisladores?, Porto Alegre, Sergio Antonio Fabris, 1999.

CARneiro, JoÃo Geraldo Piquet, Análise da Estruturação e do Funcionamento do Juizado de Pequenas Causas da Cidade de Nova Iorque, in Watanabe, Kazuo (org.), Juizados Especiais de Pequenas Causas: Lei 7.244, de 7 de novembro de 1984, São Paulo, Revista dos Tribunais, 1985, pp. 23 a 36.

Carneiro, Paulo Cezar Pinheiro, Acesso à Justiça, Rio de Janeiro, Forense, 2003.

Carvalho, José Murilo De, Cidadania no Brasil: O longo caminho, Rio de Janeiro, Civilização Brasileira, 2002.

Castelar, Armando (org.), Judiciário e Economia no Brasil, São Paulo, Sumaré, 2000.

Cavalcante, Rosângela Batista, Juizados Especiais Cíveis (JECs) e faculdades de direito, in Maria Tereza SADEK (org.), Acesso à Justiça, São Paulo, Konrad Adenauer, 2001, 123 a 154.

CEBEPEJ, Pesquisa Juizados Especiais Cíveis, 2003.

Chimenti, Ricardo Cunha, Teoria e Prática dos Juizados Especiais Cíveis Estaduais e Federais, São Paulo, Saraiva, 2005.

Cintra, Antonio Carlos Araújo, Grinover ,Ada Pellegrini e Dinamarco Cândido Rangel, Teoria Geral do Processo, São Paulo, Malheiros, 2006. 
Comparato, FÁBio Konder, A Evolução Histórica dos Direitos Humanos, São Paulo, Saraiva, 2002.

CruZ, Sebastião C. Velasco E, Alguns Argumentos sobre Reformas para o Mercado, in Lua Nova, no 45, 1998, pp. 5 - 27.

Cunha, LuCiana Gross SiqueIRA, Juizado Especial: ampliação do acesso à Justiça?, in Maria Tereza SADEK (org.), Acesso à Justiça, São Paulo, Konrad Adenauer, 2001, pp. $43-69$.

Cunha, LuCiANA Gross SiqueIRA, Juizado Especial: criação, instalação e funcionamento e a democratização do acesso à justiça, São Paulo: Universidade de São Paulo, Departamento de Ciência Política, Tese de Doutoramento, 2005.

Cunha, LuCiana Gross Siqueira, O acesso à justiça e a assistência jurídica em São Paulo, São Paulo: Universidade de São Paulo, Departamento de Ciência Política, Dissertação de Mestrado, 1999.

D’AraúJo, Maria Celina, Juizados Especiais de Pequenas Causas: notas sobre a experiência no Rio de Janeiro, in Justiça e Cidadania, Rio de Janeiro, Centro de Pesquisa e Documentação de História Contemporânea do Brasil, Fundação Getúlio Vargas, Vol. 9, n. 18, 1996, pp. 301 - 322.

Desasso, AlCIR, Juizado Especial Cível: Um Estudo de Caso, Universidade de São Paulo, Departamento de Ciência Política, Dissertação de Mestrado, 2001.

Diniz, Eli, Uma Perspectiva Analítica para a Reforma do Estado, in Lua Nova, n 45, 1998, pp. $29-48$.

FAISTING , ANDRÉ Luís, O Dilema da Dupla Institucionalização do Poder Judiciário, in in SADEK, Maria Tereza (org.), O Sistema de Justiça, Série Justiça, São Paulo, Idesp/Sumaré, 1995, pp. 46 a 52.

Ferraz JR, TÉrcio SAMPAio., O Judiciário Frente à Divisão dos Poderes: Um Princípio em Decadência?, in Revista USP, n 21, 1994, pp. 12 a 21.

Grinover, Ada Pellegrini; Gomes Filho, Antônio Magalhães; Fernandes, Antonio SCARANCE; GOMES, Luís Flávio, Juizados Especiais Criminais: Comentários à Lei 9.099, de 26.09.1995, São Paulo, Revista dos Tribunais, 1996.

Grinover, Ada Pellegrini, Vasconcelos e Benjamin, Antônio Herman de, Fink, Daniel Roberto, Filomeno, José Geraldo Brito, Watanabe, KaZuo, Nery Júnior, Nelson, Denari, Zelmo, Código Brasileiro de Defesa do Consumidor Comentado pelos Autores do Anteprojeto, Rio de Janeiro, Forense, 2001. 
Haddad, Eneida Gonçalves de Macedo; Sinhoretto, Jacqueline e Pietrocolla, Luci GATI, , Justiça e Segurança na periferia de São Paulo: os centros de integração da cidadania, São Paulo, IBCCrim, 2003.

IBGE, Classificação Nacional de Atividades Econômicas - Versão 1.0, disponível on line em www.ibge.gov.br, último acesso em 10/04/2006.

Lagrasta Neto, Caetano, Juizado Especial de Pequenas Causas e Direito Processual Civil Comparado, in Watanabe, Kazuo (org.), Juizados Especiais de Pequenas Causas: Lei 7.244, de 7 de novembro de 1984, São Paulo, Revista dos Tribunais, 1985, pp. $37-101$.

Majone, Giandomenico, From the Positive to the Regulatory State: Causes and Consequences of Changes in the Mode of Governance, Working Paper 93, Madrid, Instituto Juan March de Estudios e Investigaciones, 1997.

Marques Neto, Floriano Azevedo, A Nova Regulação Estatal e as Agências Independentes, in Sundfeld, CARlos ARI (org.), Direito Administrativo Econômico, São Paulo, Malheiros/SBDP, 2000, pp. 72 - 98.

Marshall, T. H., Cidadania, Classe Social e Status, Rio de Janeiro, Jorge Zahar, 1967.

Melo, Marcus André, A Política da Ação Regulatória: Responsabilização, Credibilidade e Delegação, in Revista Brasileira de Ciências Sociais, Vol. 16, 2001, n 46, pp. 55 68.

Melo, Marcus André, Política Regulatória: Uma Revisão da Literatura, BIB, 2000, nº 50, pp. $7-47$.

MinistéRIO da AdministraçÃo e Reforma do Estado, Plano Diretor da Reforma do Estado, Brasília, 1995.

MinistÉRio DA JustiÇA, Estudo Diagnóstico Defensoria Pública no Brasil, Brasília, 2004, disponível on line in http://www.justica.gov.br/reforma/pdf/publicacoes/Diag_defensoria.pdf.

MinistÉRIO DA JustiÇA/CEBEPEJ, Juizados Especiais Cíveis: Estudo, Brasília, 2006

Nascimento, Renata, A Mudança de Papel do Estado Brasileiro: Uma análise dos Anos 50 aos Anos 90, in Benecke, Dieter W. e Nascimento, Renata (orgs.), Opções de Política Econômica para o Brasil, Rio de Janeiro, Konrad Adenauer, 2003, pp. 187 206.

Pereira, Luiz Carlos Bresser, A Reforma do Estado dos Anos 90: Lógica e Mecanismos de Controle, in Lua Nova, no 45, 1998, pp.49 - 95. 
Przeworski, Adam, States and Markets: A Primer in Political Economy, Cambridge, Cambridge University, 2003.

Rezende, Flávio da Cunha, Por que as Reformas Administrativas Falham?, in Revista Brasileira de Ciências Sociais, Vol. 17, 2002a, nº 50, pp. 123 - 142.

Rezende, Flávio da Cunha, Razões da Crise de Implementação do Estado Gerencial: Desempenho Versus Ajuste Fiscal, Revista de Sociologia Política, 2002b, nº 19, pp. $111-121$.

Rodrigues, Horácio Wanderley, O Poder Judiciário no Brasil, in Kegel, Patrícia LuízA (org.), O Terceiro Poder em crise: impasses e saídas, Cadernos Konrad Adenauer III (2002), nº 6, Rio de Janeiro, Fundação Konrad Adenauer, 2003, pp. 13 a 53.

SADEK, MARIA TerezA, A Organização do Poder Judiciário no Brasil, in SADEK, MARIA TEREZA (org.), Uma Introdução ao Estudo da Justiça, Série Justiça, São Paulo, Idesp/Sumaré, 1995, pp. 9 a 16.

SAdek, Maria Tereza, Lima, Fernão Dias de e AraúJo, José Renato de, O Judiciário e a Prestação de Justiça, in Maria Tereza SAdeK (org.), Acesso à Justiça, São Paulo, Fundação Konrad Adenauer, 2001, p. 13 a 42.

SAnches Filho, Alvino Oliveira, As Experiências de Acesso à Justiça, in SADEK, Maria Tereza (org.), Acesso à Justiça, São Paulo, Fundação Konrad Adenauer, 2001, p. 80 a 92

SAntos, BoAventura de Souza Pela Mão de Alice: O social e o político na pósmodernidade, São Paulo, Cortez, 2001.

Secretaria da Justiça e Defesa da Cidadania do Governo do Estado de São Paulo, Projeto Técnico dos Centros de Integração da Cidadania, disponível on line in www.justica.sp.gov.br/Cic/projeto_tecnico_cic.doc, último acesso em 19/07/2005.

Secretaria do DesenVolvimento, Trabalho e Solidariedade - PMSP, 2000, disponível on line in www.prefeitura.sp.gov.br, último acesso em 19/07/2005.

Sen, Amartya, Desenvolvimento como Liberdade, São Paulo, Companhia das Letras, 1999.

STF, É preciso reduzir as causas de litigiosidades", diz Jobim em reunião com dirigentes do Banco Central, Aneel e Anatel, disponível on line in http://www.stf.gov.br, último acesso em 05/08/2004

Tribunal de JustiçA do Estado De SÃo Paulo, Relatório Anual de Gestão 2003 
Tribunal de Justiça do Estado do Rio de Janeiro, Perfil das Maiores Demandas Judiciais do Tribunal de Justiça do Estado do Rio de Janeiro, 2004

Vianna, Luiz Werneck; Carvalho, Maria Alice Rezende de; Melo, Manoel Palacios Cunha e Burgos, Marcelo Baumann, A Judicialização da Política e das Relações Sociais no Brasil, Rio de Janeiro, Revan, 1999

VIEIRA, OsCar VILHENA, Império da Lei ou da Corte, in Revista USP, n 21, 1994, pp. 70 a 77.

Watanabe, Kazuo (org.), Juizados Especiais de Pequenas Causas: Lei 7.244, de 7 de novembro de 1984, São Paulo, Revista dos Tribunais, 1985. 